Illinois State University

ISU ReD: Research and eData

Theses and Dissertations

$4-17-2019$

\title{
Capture Zone Analysis of a Wellfield to Assess Contaminant Transport
}

Prince Kojo Oware

Illinois State University, pkoware24@gmail.com

Follow this and additional works at: https://ir.library.illinoisstate.edu/etd

Part of the Hydrology Commons

\section{Recommended Citation}

Oware, Prince Kojo, "Capture Zone Analysis of a Wellfield to Assess Contaminant Transport" (2019).

Theses and Dissertations. 1119.

https://ir.library.illinoisstate.edu/etd/1119

This Thesis is brought to you for free and open access by ISU ReD: Research and eData. It has been accepted for inclusion in Theses and Dissertations by an authorized administrator of ISU ReD: Research and eData. For more information, please contact ISUReD@ilstu.edu. 


\title{
CAPTURE ZONE ANALYSIS OF A WELLFIELD TO ASSESS CONTAMINANT TRANSPORT
}

\author{
Prince Kojo Oware
}

78 Pages

Radium is a common contaminant to the deep Cambrian- Ordovician aquifer in northern Illinois. Deep groundwater aquifers are used as fresh water resource in many parts of the world. Due to overuse, increase in salinity, natural and human-driven contamination, sustainability of these aquifer systems is uncertain. The purpose of this study is to better understand the groundwater flow system in deep bedrock aquifers in northern Illinois, and its control on the radium contamination in Rochelle's Public Water Supply Wells (PWSW). We have tested two hypotheses: (1) the Radium (Ra) transport is driven by large pumping centers that interrupt groundwater flow (groundwater divide) and direct elevated level of Ra from areas that have already recorded Ra to PWSW and (2) Increased pumping results in leakage of water from the Franconia Formation which is fraught with glauconite into the PSWS that is opened to the IrontonGalesville aquifer. The hypotheses are tested using a 3D steady-state numerical groundwater model using MODFLOW. The numerical model was calibrated using in-situ groundwater level measurement data, and pseudo wells created from head data from Illinois Groundwater Flow Model (IGWFM), with Mean Error (ME), Root Mean Squared Error (RMSE), and coefficient of determination $\left(\mathrm{R}^{2}\right)$ values of $0.07 \mathrm{~m}, 1.74 \mathrm{~m}$, and 0.991, respectively. Using the calibrated model, scenario models, stochastic and capture zone analysis were conducted. The results indicated that the large pumping centers have less control on the shift in regional groundwater divide, hence preventing flow of radium rich waters to Rochelle's PWSW. On the other hand, capture zone results and mass balance shows leakage from the Franconia Formation into the IrontonGalesville aquifer which might indicate the source of radium being upgradient into the PWSW. Generally, 
it is recommended to tap water from shallower bedrock aquifers located above the Franconia Formation in Rochelle.

KEYWORDS: Radium, MODFLOW, Modeling, Cambrian-Ordovician, Groundwater, Capture Zone 
CAPTURE ZONE ANALYSIS OF A WELLFIELD TO ASSESS CONTAMINANT TRANSPORT

\author{
PRINCE KOJO OWARE
}

A Thesis Submitted in Partial Fulfillment of the Requirements for the Degree of MASTER OF SCIENCE

Department of Geography, Geology, and the Environment

ILLINOIS STATE UNIVERSITY 
C2019 Prince Kojo Oware 
CAPTURE ZONE ANALYSIS OF A WELLFIELD TO ASSESS CONTAMINANT TRANSPORT

PRINCE KOJO OWARE

COMMITTEE MEMBERS:

Wondwosen Seyoum, Co-Chair

Dave Malone, Co-Chair

Eric Peterson 


\section{ACKNOWLEDGMENTS}

First and foremost, I would like to show my sincere gratitude to my thesis advisor Dr. Wondwosen Seyoum, for his constructive criticism throughout my thesis work. He helped honed my writing and made sure I was making the right decisions academically during my stay here at Illinois State University. I would like to also thank my co-chair, Dr. Dave Malone for his ideas and support for the project, and Dr. Eric Peterson for his ideas and feedback. This project would not be possible without all of your input. I would also like to thank Rochelle Municipal Utilities, especially Adam Lanning for data for this project and providing the necessary funding to make this work possible. Also, I would like to say a big thank you to the Illinois State Water Survey, especially Dr. Abrams for helping me with data from the States Regional Model. I would further like to thank the faculty of the Department of Geography, Geology and the Environment, for their input and encouragement through my stay here at Illinois State University. A huge thanks to all my colleague and friends for their feedback and help. Lastly, I would like to thank my family in Ghana for their patience and prayer, can't wait to reunite with all of you soon.

P.K.O. 


\section{CONTENTS}

Page

ACKNOWLEDGMENTS

CONTENTS

ii

TABLES

v

FIGURES

vi

CHAPTER I: INTRODUCTION

Background

Groundwater and Contamination

Radium Radiochemistry

Radium in Northern Illinois

Previous Studies on Contaminant Transport

Site Description

Stratigraphy

Structure

Study Purpose and Objectives

Research Questions

Question 1

Question 2

CHAPTER II: METHODS

Data

Conceptual Model Development

Hydrostratigraphic Layers 
Numerical Groundwater Modeling using MODFLOW $\quad 25$

$\begin{array}{ll}\text { Numerical Model Design } & 27\end{array}$

$\begin{array}{ll}\text { Model Parameters } & 29\end{array}$

$\begin{array}{ll}\text { Calibration } & 30\end{array}$

$\begin{array}{ll}\text { Calibration Targets } & 32\end{array}$

$\begin{array}{ll}\text { Calibration Statistics } & 34\end{array}$

$\begin{array}{ll}\text { Automatic Calibration } & 37\end{array}$

$\begin{array}{ll}\text { PEST Calibration Statistics } & 39\end{array}$

$\begin{array}{ll}\text { Sensitivity Analysis } & 40\end{array}$

$\begin{array}{ll}\text { Effect of Boundary Conditions } & 40\end{array}$

$\begin{array}{ll}\text { Scenario Analysis } & 42\end{array}$

$\begin{array}{ll}\text { Stochastic Modeling } & 44\end{array}$

$\begin{array}{ll}\text { Capture Zone } & 44\end{array}$

$\begin{array}{ll}\text { Mass Balance } & 46\end{array}$

$\begin{array}{ll}\text { CHAPTER III: RESULTS } & 47\end{array}$

$\begin{array}{ll}\text { Calibration and Sensitivity Analysis } & 47\end{array}$

$\begin{array}{ll}\text { Scenario Model Results } & 50\end{array}$

$\begin{array}{ll}\text { Scenario } 1 & 50\end{array}$

$\begin{array}{ll}\text { Scenario } 2 & 52\end{array}$

$\begin{array}{ll}\text { Scenario } 3 & 53\end{array}$

$\begin{array}{ll}\text { Scenario } 4 & 55\end{array}$

$\begin{array}{ll}\text { Capture Zone Results } & 56\end{array}$

$\begin{array}{ll}\text { Mass Balance Results } & 61\end{array}$

Mass Balance for Well $12 \quad 65$ 
Groundwater Flow and Model Sensitivity

Capture Zone and Mass Balance

Model Gaps and Recommendation

CHAPTER VI: CONCLUSIONS 


\section{TABLES}

Table

1. Summary of Data Sources Used for Building the Model

2. Sample of How Depth of Stratigraphic Units were Recorded

3. Summary of Initial Model Parameter Values

4. Calibration Statistics for Final Manual Calibrated Model

5. Calibrated Parameter Values for St. Peter Before and After PEST

6. Calibrated Parameter Values for Ironton- Galesville Before and After PEST

7. Calibrated Recharge Values Before and After PEST

8. Withdrawal Rates for the Three Different Pumping Centers

9. Withdrawal Rate for Different Pumping Centers for Scenario 1

10. Withdrawal Rate for Different Pumping Centers for Scenario 2

11. Withdrawal Rate for Different Pumping Centers for Scenario 3

12. Withdrawal Rate for Different Pumping Centers for the Scenario 4

13. Parameter Differences for Stochastic Models and Travel Times for Capture Zones

14. Mass Balance for the Entire Model

15. Mass Balance for St. Peter

16. Mass Balance for Franconia

17. Mass Balance for Ironton-Galesville 
FIGURES

Figure

1. Map of northern Illinois showing areas where the Maquoketa Shale is present with areas having high Ra values recorded

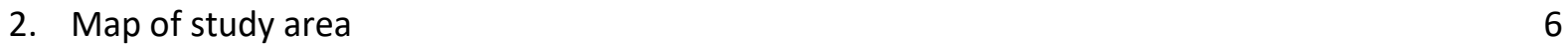

3. Stratigraphic column for northern Illinois $\quad 10$

4. Bedrock structure in northern Illinois 12

5. Map showing the regional groundwater divide separating Rochelle and DeKalb 13

6. Cross section showing shift in groundwater divide as a result of increase

in pumping

$\begin{array}{ll}\text { 7. Sample of driller's well log } & 18\end{array}$

8. Conceptual Model for the study area 20

9. Conceptual Model generated in GMS $\quad 23$

10. Boundary conditions used for the groundwater flow model 25

11. Outline of methodology 27

12. Observed head values for observation wells used for calibration 30

13. Location of observation wells used for calibration 31

14. Flowchart explaining the trial and error process used for calibration 32

15. Components of calibration target 33

16. Spatial distribution of calibration targets for the calibrated model 34

17. Plot of error vs simulation showing the calibration progress for the trial and error phase of calibration $\quad 35$

18. Correlation between observed and computed heads 36

19. Map showing zones used in PEST Calibration 38 
20. Change in boundary condition

21. Withdrawal map for year 2013 for the study area, modified from Abrams et al. (2018)

22. Map showing the head distribution within all six layers of the calibrated model

23. Scatter plot showing observed vs residual heads

24. Plot of sensitivity vs parameters

25. Calibrated Model showing the capture zone for Rochelle on the left side and parts of northeastern Illinois (DeKalb) on the right

26. Head distribution for simulated model for Scenario 1

27. Head distribution for simulated model for Scenario 2

28. Head distribution for simulated model for Scenario 3

29. Head distribution for simulated model for Scenario 4

30. A-A' cross section of Model A

31. A-A' cross section of Model B

32. A-A' cross section of Model C

33. A-A' cross section of Model D

34. Percentage stacked bar chart showing the mass balance within the St. Peter, Franconia and Ironton-Galesville

35. A-A' cross section showing the flow velocity vectors for Scenario 4 moving away from the groundwater divide

36. Cross section $A-A^{\prime}$ showing the flow velocity vectors for scenario 4 directed from the Franconia towards Ironton-Galesville 


\section{CHAPTER I: INTRODUCTION}

\section{Background}

\section{Groundwater and Contamination}

Understanding groundwater flow is important in water resource planning, water quality management, and identifying sources of contamination. The largest source of available freshwater is groundwater, and it is the most important resource for drinking, irrigation, and industrialization (Khadri and Pande, 2016). Groundwater, although separated from the land surface by tens, hundreds, or thousands of meters, is still susceptible to contamination. Therefore, the flow system must be well understood, and the aquifer should be protected and managed. Accurate information regarding contaminant source characteristics is essential for development of efficient mitigation strategy (Moise et al., 2000). In deeper aquifer systems, flow of water through the aquifer material and interaction with different layers is complicated and less understood. Groundwater withdrawals cause the subsurface water pressure (head) in aquifers to decline (Meyer et al., 2013)). Such decline in head can cause economic, biological, physical, and geochemical impacts (Meyer et al., 2013).

Identification of unknown groundwater pollution sources is a prerequisite for effective formulation of management strategy. (Moise et al., 2000). The common radionuclides in groundwater are products of the uranium $(\mathrm{U})$ and thorium $(\mathrm{Th})$ decay series of which radium $(\mathrm{Ra})$ is a decay product (Szabo et al., 2012). Decay of U nuclide propels the Th nuclides into a solution, also the Th may, in turn, eject Ra into solution (Kelly, 2008).

\section{Radium Radiochemistry}

$\mathrm{Ra}$ is an isotope and an alkaline-earth group. An isotope is two or more forms of the same element that contains equal number of protons but different number of neutrons in their nuclei, and hence difference in relative atomic mass but not in its chemical properties. Ra has four commonly occurring isotopes, which are ${ }^{223} \mathrm{Ra},{ }^{224} \mathrm{Ra},{ }^{226} \mathrm{Ra}$, and ${ }^{228} \mathrm{Ra}$ of which two $\left({ }^{226} \mathrm{Ra}\right.$ and $\left.{ }^{228} \mathrm{Ra}\right)$ are significant to 
groundwater. Due to the importance of those two isotopes in groundwater, Ra concentrations in groundwater are usually reported with respect to the combined concentration of those two isotopes, ${ }^{226} \mathrm{Ra}$ and ${ }^{228} \mathrm{Ra}$ with half-lives of 1600 years and 5.75 years, respectively (Kelly, 2008). Ra concentrations in groundwater differ because of differences in chemical properties of the parent isotopes at the head of the decay series, either ${ }^{232} \mathrm{Th},{ }^{235} \mathrm{U}$, or ${ }^{238} \mathrm{U}$ (Stackelberg, 2018). The Thorium isotopes ${ }^{228} \mathrm{Th}^{230} \mathrm{Th}$, and ${ }^{232} \mathrm{Th}$, which are said to be insoluble in groundwater, are the immediate radioactive sources for ${ }^{226} \mathrm{Ra}$, ${ }^{228} \mathrm{Ra}$, and ${ }^{224} \mathrm{Ra}$ respectively (Stackelberg, 2018). ${ }^{224} \mathrm{Ra}$ has a half-life of 3.6 days and its concentration declines rapidly after about one half-life, whiles ${ }^{223}$ Ra occurs infrequently in the environment at high concentrations (Stackelberg, 2018), hence both are not reported for combined Ra levels in drinking waters.

Ra has been identified as the most potentially hazardous naturally occurring radionuclide likely to occur in drinking water (Szabo et al., 2012). Radium in drinking water increases cancer risk, primarily bone and sinus cancers (Szabo et al., 2012). The risk incurred from alpha particle emission depends on the way the body metabolizes the ingested radionuclide (Szabo et al., 2012). The Maximum Contaminant Level (MCL) for combined Ra is 5 picocuries per liter $(\mathrm{pCi} / \mathrm{L})$, which is set by the United States Environmental Protection Agency (USEPA) (Stackelberg, 2017).

\section{Radium in Northern Illinois}

The Cambrian-Ordovician aquifer system underlies area of $476,560 \mathrm{~km}^{2}$ extending across parts of Midwestern states (Stackelberg, 2018). Within the northern part of Illinois, the Cambrian-Ordovician aquifer system is used as an important source of domestic and public water supplies. Concentrations of naturally occurring radioactive isotopes ${ }^{226} \mathrm{Ra}$ and ${ }^{228} \mathrm{Ra}$ in excess of the USEPA standard for drinking water has been detected in water from deep bedrock aquifers used for public water supply (Kay, 1999). One of the distinct stratigraphic difference between areas having higher concentration of Ra recorded in drinking water supplies and areas not having higher concentration is the presence of the Maquoketa 
Shale (Figure 1). Regionally, the lowest Ra concentrations are in zones of primary recharge to the deep bedrock aquifer that is counties such as Boone, DeKalb and counties to the west, where the confining Maquoketa Shale is absent (Kelly, 2008). The Maquoketa Shale, which acts as a confining unit for most areas of northern Illinois, is eroded in areas such as Carrol, Boone, Winnebago, La Salle, and parts of Stephenson, Lee, and Ogle counties (Figure 1). In areas where the Maquoketa Shale is absent, fine grained glacial drift and/or dense unfractured dolomite of the Galena and Platteville group are present on the ground surface (Gilkerson, 1983). Gilkerson, (1983) analyzed selected natural radioisotopes and barium within groundwater in Cambrian-Ordovician aquifer systems in Illinois and obtained Ra values for 90 combined analyses to range from 0.2 to $41.0 \mathrm{pCi} / \mathrm{L}$. Gilkerson, (1983) found higher Ra values recorded in groundwater where the Cambrian and Ordovician bedrock are confined with the Maquoketa Shale.

A more generalized study on the occurrence of Ra in groundwater in major aquifers of United States conducted by the U.S Geological Survey (U.S.G.S) with participation from the USEPA, discovered that elevated Ra concentrations in groundwater occurs mostly from aquifers in the eastern and central United States. The highest concentrations of Ra were observed in the Mid-Continent and Ozark Plateau, Cambrian-Ordovician aquifer systems and the northern Atlantic Coastal Plain aquifer systems (Szabo et al., 2012) where more $20 \%$ of groundwater samples exceeded the combined MCL for Ra (Szabo et al., 2012). Ra above the MCL has also being detected in communities in Georgia, North Carolina, South Carolina, and Virginia (Cline et al, 1983; Michael and More, 1980) where they fall along the fall line that separates the Piedmont Province and Coastal Plain Province. The occurrence within the fall line was attributed to the granites within the Piedmont Province and sands that makes up the Coastal Plain 
Province where uranium and thorium bearing minerals release ${ }^{226} \mathrm{Ra}$ and ${ }^{228} \mathrm{Ra}$.

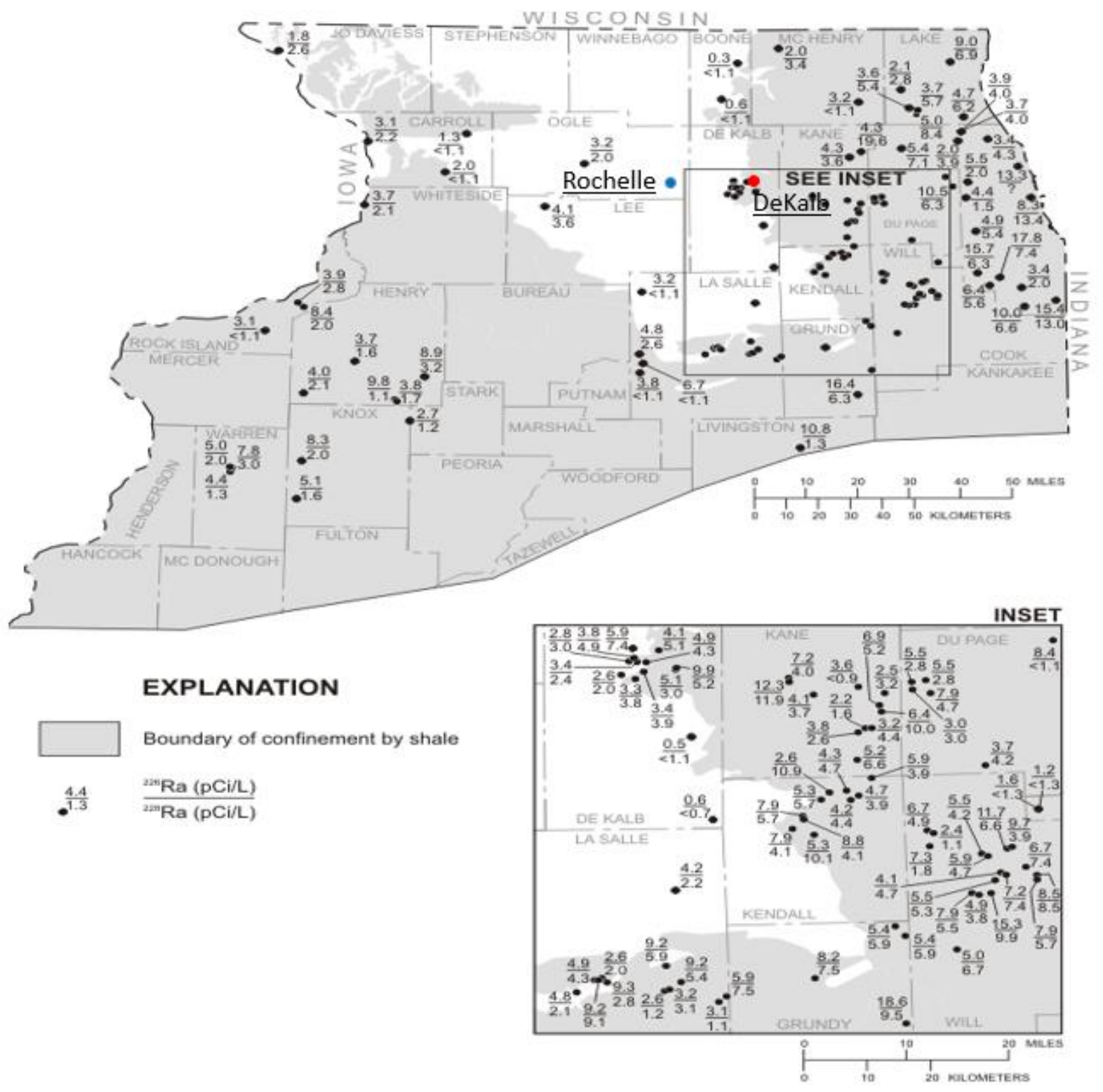

Figure 1. Map of northern Illinois showing areas where the Maquoketa Shale is present with areas having high Ra values recorded. Blue dot shows location of Rochelle and red dot for DeKalb (Kay, 1999). Previous Studies on Contaminant Transport

With previous studies having been able to ascertain the occurrence of high Ra concentration within the sandstone aquifer of the Cambrian-Ordovician system, a more practical approach such as modeling 
of the groundwater flow that helps to understand the source/path of Ra within the subsurface is needed. Moise et al. (2000) sampled 36 springs and wells within the Dead Sea Rift valley to understand the activities of $\mathrm{Ra}$ isotopes and to suggest high radon enrichment common to all water sources on the Dead Sea Rift Valley. Moise et al. (2000) found out fast upward flow and continual mixing in the Dead Rift Valley accounts for constant replenishment of Ra in waters. Also, mixing of radium-extracting brines with freshwater leads to continual adsorption of radium as water salinity decreases. Sengor and Unlu, (2013) used a transient numerical model using GMS (Groundwater modeling system) to analyze the groundwater flow and contaminant transport of acrylonitrile at a spill site in Turkey. Sengor and Unlu, (2013) were able to use their groundwater model to better understand the hydrogeological parameters of the site, which helped in containing the offsite migration of the contaminant plume. Weaver and Bahr (1991) used a finite difference groundwater flow model linked to a particle tracking routine to determine groundwater flow paths and residence times of Ra in the Cambrian-Ordovician Sandstone aquifer of eastern Wisconsin. Weaver and Bahr (1991) found out Ra activities in groundwater increases with distance and flow paths. Carlock et al (2016) built a groundwater flow model using GFLOW and MODPATH for particle tracking in order to study the feasibility of the movement of contamination from a $\mathrm{CO}_{2}$ sequestration site to Lake Decatur. Advances in regional groundwater flow modeling are influenced by the demand to predict regional impact of human interference on groundwater systems and associated environment (Zhou and Li, 2011). Groundwater flow models are a valuable tool for hydrogeologist to perform various tasks including understanding the inflow of water into different public wells. The rapid increase of computing power and the availability of user-friendly modeling software has enabled simulation of large-scale regional groundwater systems (Zhou and Li, 2011).

\section{Site Description}

The study was located in northern Illinois, specifically Ogle, DeKalb and Lee counties (Figure 2). The total area of study is 1633.5 square kilometers. The mean annual precipitation is approximately $930 \mathrm{~mm}$ 
and mean temperature of around $4{ }^{\circ} \mathrm{C}$. There are hundreds of domestic wells penetrating through the Cambrian-Ordovician systems within the study area but are mainly opened to either the St. Peter Sandstone, Ironton-Galesville Sandstone, or both.

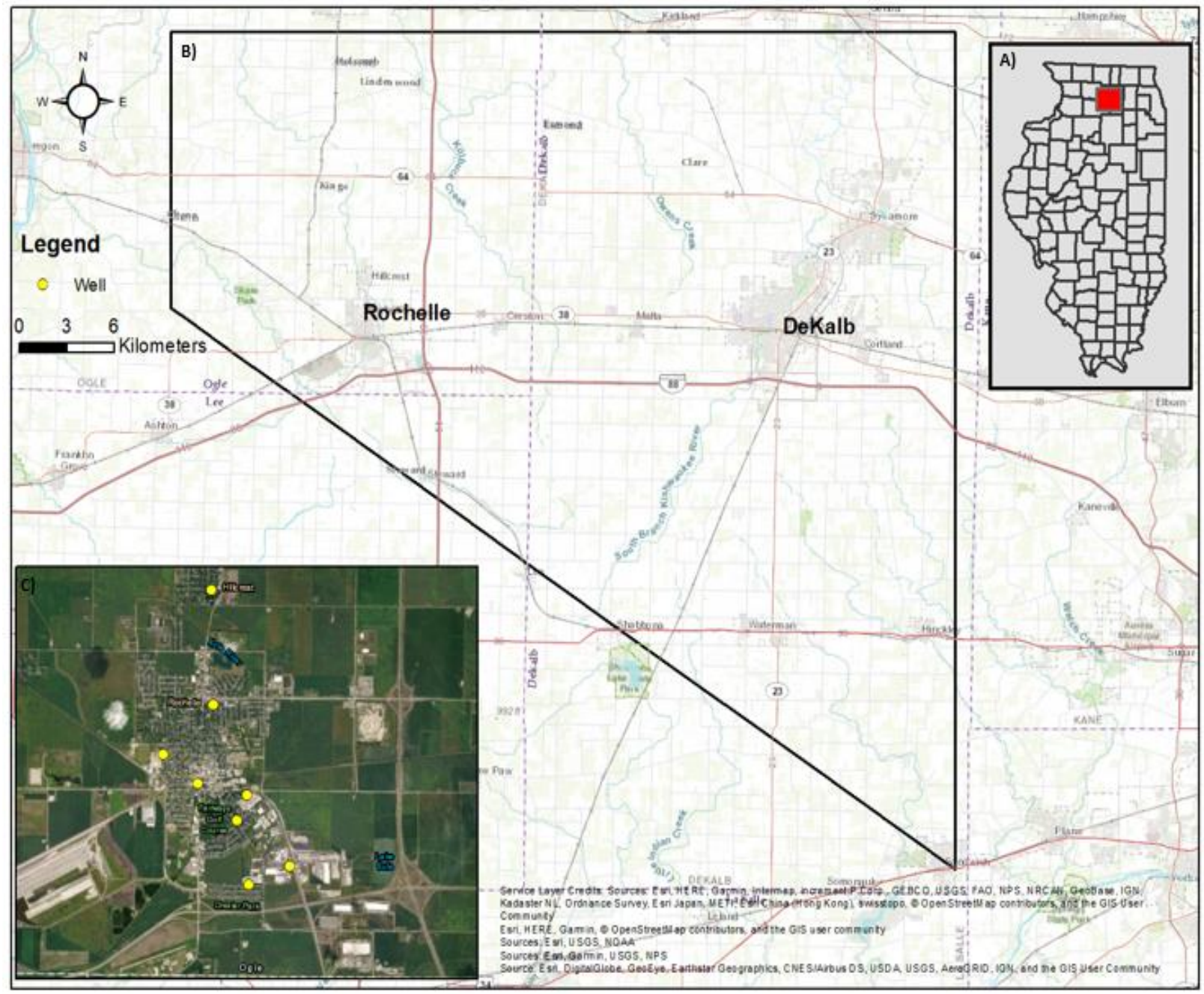

\section{Stratigraphy}

The stratigraphy of the study area from the oldest to the youngest unit is presented below;

\section{Eau Claire}

The Eau Claire Formation overlies the Mt. Simon Sandstone within northern Illinois (Figure 3). The Eau Claire Formation consists mainly of dolomitic siltstone and sandstone with interbedded dolomite and shale (Kolata and Nimz, 2010). The shale, siltstone and, and dolomite of the Eau Claire Formation 
acts as a confining unit (Panno et al., 2018). The formation ranges in thickness from about $61 \mathrm{~m}$ in western Illinois to more than $370 \mathrm{~m}$ in southern Illinois (Kolata and Nimz, 2010). However, within the study area, it ranges in thickness between $106 \mathrm{~m}$ to $137 \mathrm{~m}$ (Kolata et al., 1978).

Ironton and Galesville Sandstone

The Ironton and Galesville Sandstones are well exposed in towns in southern Wisconsin. The Ironton and Galesville Sandstone constitute the most productive bedrock aquifers in northern Illinois (Kolata and Nimz, 2010; Visocky et al., 1985). The Galesville Sandstone overlies the Eau Claire and it is a fine grained, well sorted, clean sandstone that is generally free from glauconite (Kolata et al., 1978). The overlying Ironton Sandstone is medium grained, moderately sorted, partly dolomitic sandstone (Kolata et al., 1978). The Ironton and Galesville Sandstones are combined as a single formation with a thickness ranging from $46 \mathrm{~m}$ to $61 \mathrm{~m}$ (Kolata and Nimz, 2010).

\section{Franconia Formation}

The Cambrian Franconia Formation consists of interbedded shale, siltstone, and sandstone that is between 15 -46m (Roads and Malone, 2018; Seid, 2010). The Sandstone is light gray to greenish gray, very fine grained and subrounded with thin laminated bedding (Seid, 2010). Siltstone of the Franconia Formation is medium gray to brownish and interbedded with shale (Seid, 2010). Franconia Formation rocks are the oldest rocks exposed in Illinois and are present in outcrops near Ashton and Oregon which is close to our study area (Kolata and Nimz, 2010). The Franconia formation is fraught with glauconite with many parts of the unit stained with orange iron oxide (Seid, 2010, Kolata et al., 1978).

Eminence and Potosi Dolomite

By the Trempealeauan time, the middle carbonate facies belt shifted northward again, and the Potosi and Eminence Dolomite covered most part of Illinois (Kolata and Nimz, 2010). The Potosi Dolomite overlies the glauconitic sandstone of the Franconia Formation in northern Illinois. The Potosi Dolomite consists of fine-grained, light brown to light gray dolomite with traces of glauconite near the 
top and bottom (Kolata and Nimz, 2010; Kolata, 2014). The Eminence Formation on the other hand, is light colored, fine to medium grained dolomite that commonly contains sands and oolitic chert. The thickness of the Eminence Dolomite in the study area is $15 \mathrm{~m}$ (Kolata et al., 1978). Both the Eminence and Potosi dolomites are fractured which can yield small amount of water (Kolata et al., 1978). The thickness of the Potosi is about $40 \mathrm{~m}$ thick and is exposed in areas near Rochelle, Ashton and Oregon (Kolata et al., 1978).

\section{St. Peter Sandstone}

The St. Peter Sandstone overlies the Potosi Dolomite within the study area (Figure 3). The St. Peter Sandstone is a supermature quartz sands that is light gray to coarse, well rounded, well sorted and thick bedded (Kolata and Nimz, 2010; Kolata, 2014). The pure quartz sands of the St. Peter were deposited in an advancing shoreline dominated by eolian dune and beach processes (Kolata and Nimz, 2010). The formation is well exposed in north-central Illinois, areas such as Starved Rock and Matthiessen Park. Locally, the St. Peter Sandstone is between 73-137 m thick (Rhoads and Malone, 2018). The St. Peter is known to be a prolific aquifer that supplies a lot of water to northern Illinois (Abrams et al., 2015). Also, due to the St. Peters purity, it is mined for glass making and other uses (Kolata and Nimz, 2010). Glenwood Formation

The Ordovician aged Glenwood Formation is an interbedded sandstone and shale that is between 0-23 m thick. The Glenwood formation forms a sharp contact with the overlying dolomite of the Platteville Formation (Kolata, 2014) and is usually used as a marker horizon for the facies transition between St. Peter sandstones and Platteville carbonate (Rhoads and Malone, 2018).

Platteville Group

The Platteville Group conformably overlies the St. Peter Sandstone (Figure 3) and consists of five dolomite members differentiated largely by shale content and relative amount of clay (Kolata, 2014). Members of the Platteville Group includes the Quimbys Mill, Nachusa, Grand Detour, Mifflin and 
Pecatonica Members (Kolata et al., 1978; Kolata 2014). During the deposition of the Tippecanoe, advancing seas fueled the deposition of fossiliferous carbonate rocks of the Platteville Group across the midcontinent (Kolata and Nimz, 2010). The Platteville is $34 \mathrm{~m}$ thick (Kolata et al., 1978), bluish gray cherty, coarsely fossiliferous and argillaceous dolomite (Kolata, 2014).

Galena Group

The Galena Group overlies the Platteville Group rocks (Figure 3). The Galena and its equivalents extend far onto the Canadian Shield, recording one of the most extensive episodes of marine inundation during the Tippecanoe on the North American continent (Kolata and Nimz, 2010). The Galena Group consists of medium-grained light gray dolomite (Kolata et al. 1978). Within the study area section of the Galena has being eroded exposing the underlying St. Peter Sandstone; consequently, the thickness is variable. In areas when the full section is present, the thickness of the Galena is $79 \mathrm{~m}$ (Kolata et al., 1978).

Maquoketa Group Shale

The Maquoketa Shale overlies the Galena Group (Figure 3). The Maquoketa is characterized by local and regional facies where within northern Illinois the lower units is dark olive-gray, laminated, bioturbated, organic rich dolomite (Kolata and Nimz, 1978). The lower unit is overlain by the Fort Atkinson Limestone, which in turn is overlain by greenish gray, fossiliferous, dolomitic shale of the Brainard Shale (Kolata and Nimz, 2010). The Maquoketa Shale Group has thickness of $74 \mathrm{~m}$ within the study area (Kolata et al., 1978). 


\begin{tabular}{|c|c|c|c|c|}
\hline SYSTEM & GROUP & FORMATION & HYDROSTRATIGRAPHIC UNIT & $\begin{array}{l}\text { GENERALIZED } \\
\text { LITHOLOGY }\end{array}$ \\
\hline \multirow{5}{*}{ 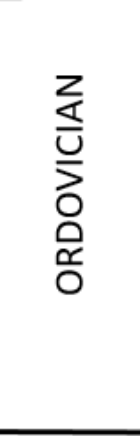 } & Maquoketa & & Maquoketa & Shale \\
\hline & Galena & & \multirow{2}{*}{ Galena- Platteville } & \multirow{2}{*}{ Carbonate } \\
\hline & Platteville & & & \\
\hline & \multirow{2}{*}{ Ancell } & Glenwood & \multirow{2}{*}{ St. Peter } & \multirow{2}{*}{ Sandstone } \\
\hline & & St. Peter & & \\
\hline \multirow{5}{*}{ 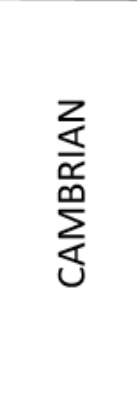 } & & Potosi & \multirow{2}{*}{ Potosi-Franconia } & \multirow[b]{2}{*}{ Carbonate } \\
\hline & & Franconia & & \\
\hline & & $\begin{array}{l}\text { Ironton- } \\
\text { Galesville }\end{array}$ & Ironton-Galesville & Sandstone \\
\hline & & Eau Claire & Eau Claire & Shale and Carbonate \\
\hline & & Mt. Simon & Mt. Simon & Sandstone \\
\hline \multicolumn{4}{|c|}{ PRECAMBRIAN } & Crystalline \\
\hline
\end{tabular}

Figure 3. Stratigraphic column for northern Illinois. The Maquoketa, Galena, Platteville, and St. Peter comprises the bedrock geology of the area. The red outline comprises the hydrostratigraphic units used for the model. (St.= Saint, Mt.= Mount)

\section{Structure}

The Wisconsin Arch, La Salle Anticlinal Belt, Plum River Fault Zone, and Sandwich Fault Zone dominates the regional structure of northern Illinois (Kolata and Graese,1983). Part of the study area contains the Sandwich Fault Zone, which forms part of the termination of three major features; Wisconsin Arch, the Kankakee Arch, and La Salle Anticlinal Belt (Kolata et al. 1978). Sandwich Fault Zone

The Sandwich Fault Zone extends from Manhattan Will County and continues to the northwest for about 137 km, to near Oregon and 1.6- 3.2 km wide (Seid, 2010; Hadley et al. 2018). The Sandwich Fault Zone has variable displacement, as much as $243 \mathrm{~m}$ (Hadley et al., 2018). The Sandwich Fault Zone has 
undergone several movements throughout geologic time, first in Devonian and then in late Paleozoic time (Seid, 2010). Within the study area, the Sandwich Fault displaces the bedrock units except the quaternary units and tends to dictate flow in northeastern and northcentral Illinois. The individual hydrostratigraphic units are vertically displaced, interfering with lateral groundwater flow (Abrams et al., 2015).

Oregon Anticline

The Oregon Anticline is one of the minor structural features located within the study area (Figure 4). The Oregon anticline is a broad low flexure located on the northeast (downthrown) side of the Sandwich Fault Zone, and trends parallel to the fault zone (Seid, 2010). The Oregon anticline is probably genetically related to the Sandwich Fault Zone (Seid, 2010) 


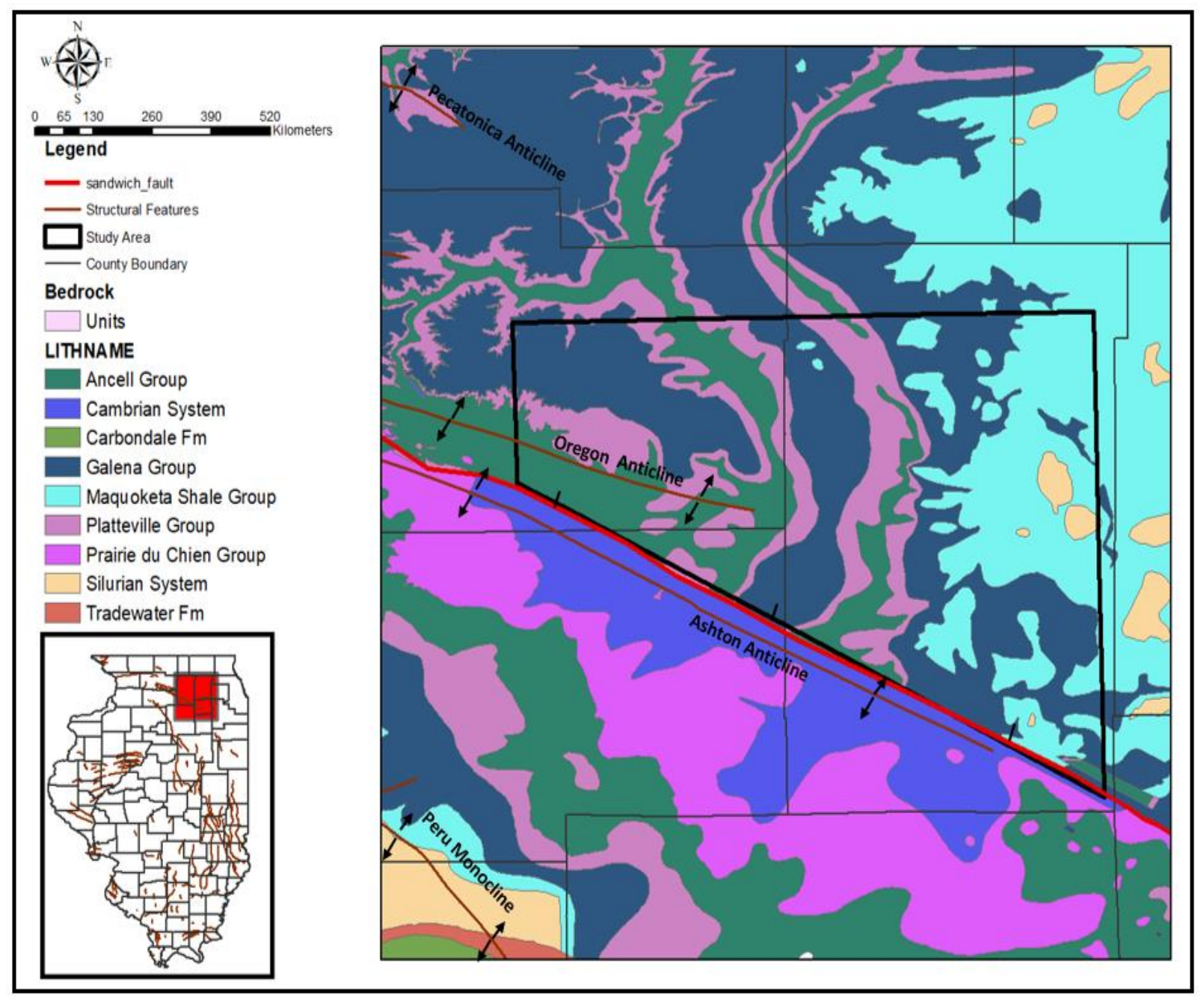

Figure 4. Bedrock structure in northern Illinois. The study area is outlined in black. The southern boundary of the study area runs parallel with the Sandwich Fault which is outlined in red on the map. Contacts for bedrock units were obtained from Illinois State Geological Survey

\section{Study Purpose and Objectives}

On April 13, 2016 Rochelle Municipal Utilities (RMU) was notified that the level of Ra sampled at one of the city's five wells (Well 12) exceeded the 5 picoCurie per liter ( $\mathrm{pCi} / \mathrm{L}$ ) MCL enforced by the USEPA. 
The purpose of this research is to understand the flow system within Rochelle wellfield in northern Illinois and to assess the occurrence of radium. We will address the objective of this research by building a 3D numerical groundwater flow model linked to a particle tracking routine. Numerical models provide a convenient method for determining groundwater flow paths and estimating velocities (Weaver, 1991; Lin et al., 2017). This study encompasses transition from unconfined to confined aquifer conditions, presence of a regional groundwater divide (Figure 5) and a fault.

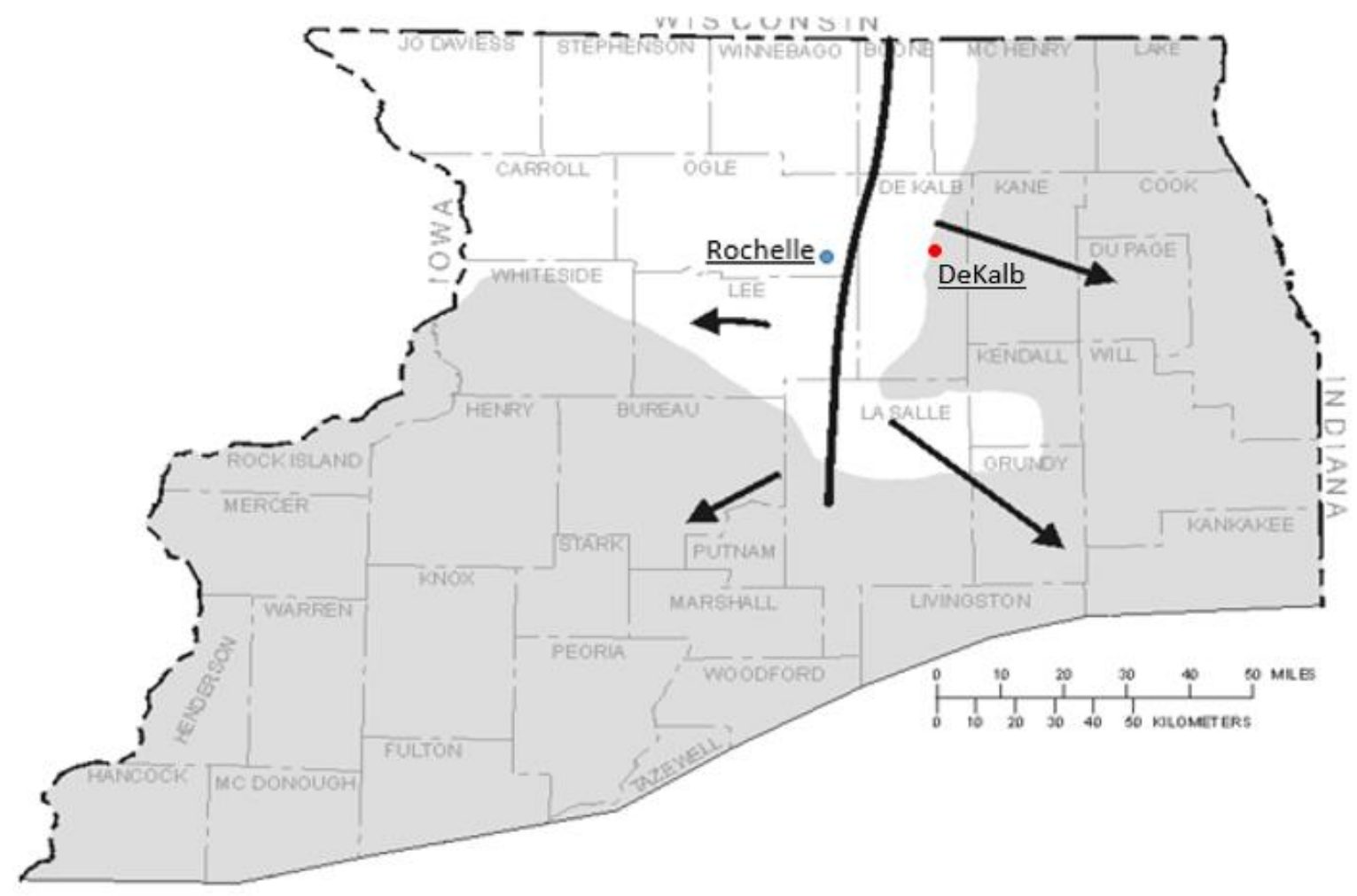

\section{EXPLANATION}

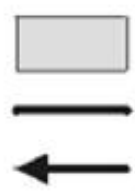

Are as where combined radium concentration shave be en de tected in excess of 5 picocuries per liter

Ground-wate r divide

General drection of gro und-water flow

Figure 5. Map showing the regional groundwater divide separating Rochelle and DeKalb. Dark background represents areas where combined Ra has been detected exceeding the MCL (Kay, 1999). 
Utilizing the model, the relationship between the different pumping scenarios and how that affects the transport of Ra will be investigated. With the capture zone of Rochelle delineated, we assessed the possibility of water moving laterally from areas that has already recorded high Ra into the wellfield and water moving upgradient from the Franconia formation into the pumping wells. Based on the high amount of pumping from the northeastern Illinois and the cone of depression within the Rochelle area, movement of water from areas that has recorded Ra into Rochelle wellfield is likely. Shift in groundwater divide occur as a result of increase in pumping centers affecting the natural flow paths (Figure 6). 


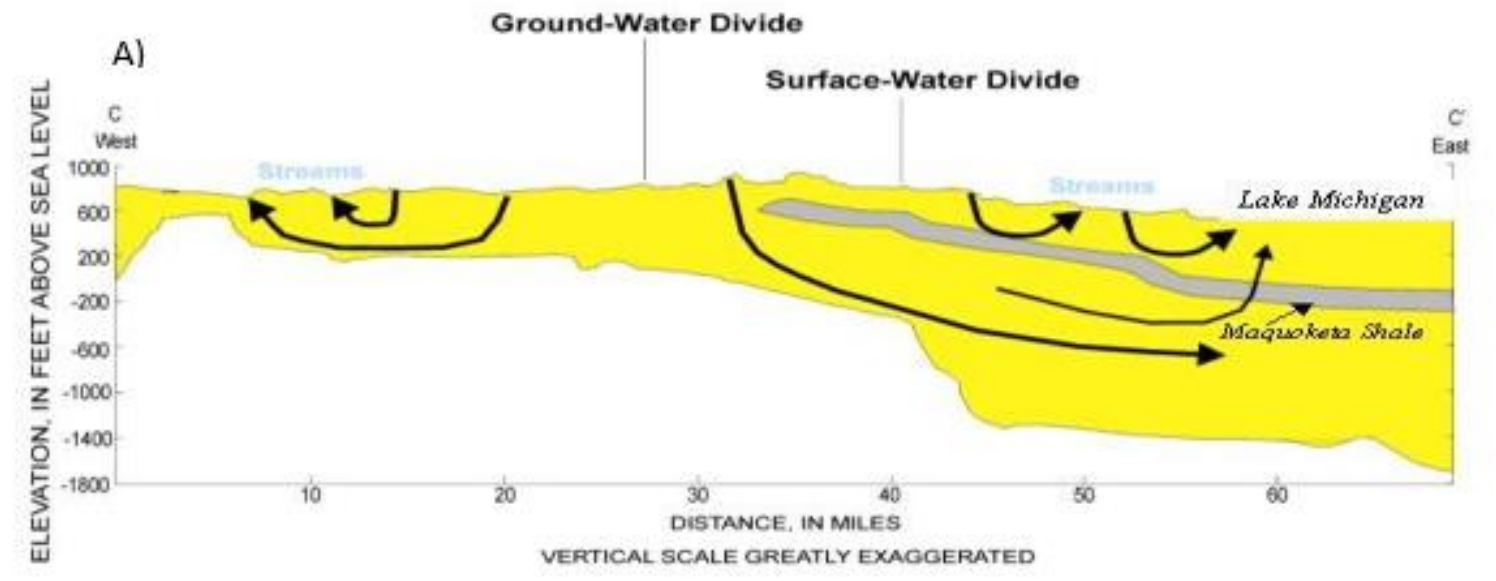

\section{Predevelopment}

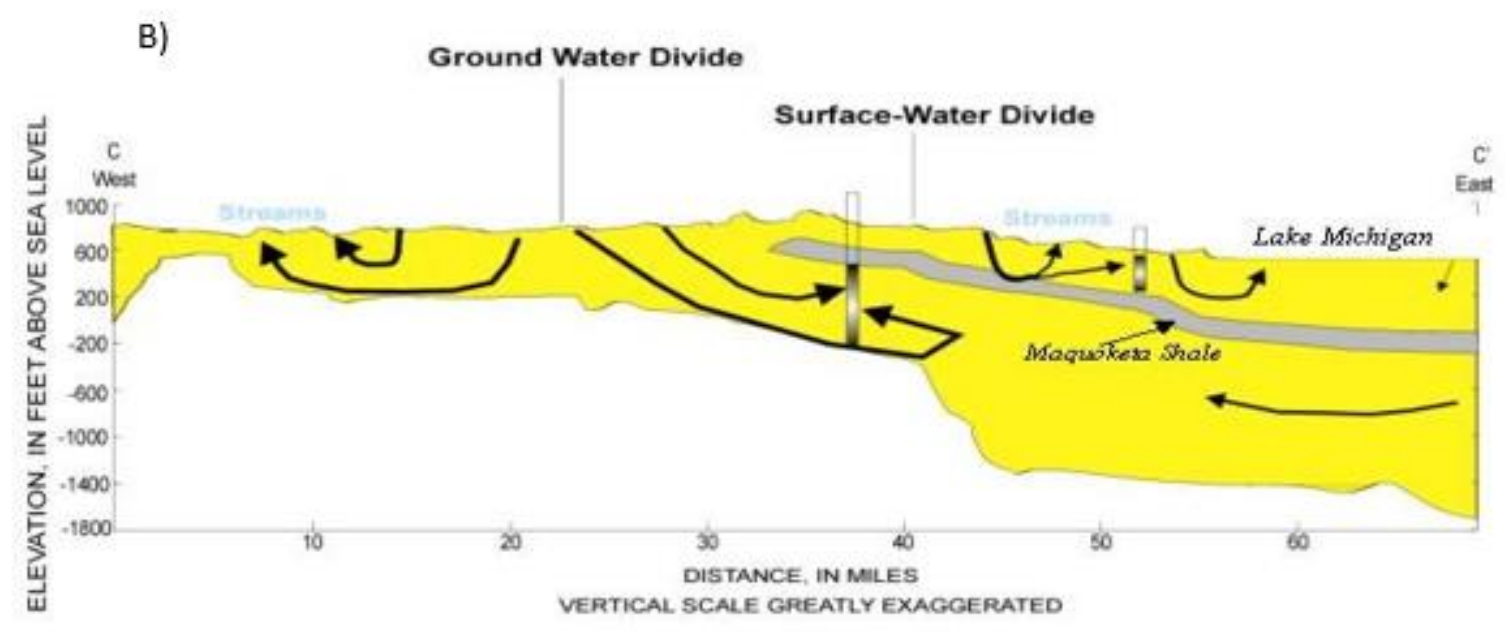

Well Development

Figure 6. Cross section showing shift in groundwater divide as a result of increase in pumping A) represents the initial flow paths without pumping, B) represents change in flow path induced by well development (Krohelski and Feinstein, 2007). 


\section{Research Questions}

\section{Question 1}

Does increase in pumping results in the flow reversal of Ra contaminated waters into the Rochelle's wellfield? A study conducted by the United States Geological Survey in September 1999 to delineate areas with high Ra in northern Illinois found most of the areas having high radium level to be located east of the Rochelle area where we have the confinement by Maquoketa Shale (Figure 1). DeKalb, a town east of Rochelle was designated as part of the areas where Ra levels above the MCL was recorded (Figure 1).

\section{Question 2}

Is there leakage form the overlying Franconia Formation into the Ironton-Galesville aquifer during pumping? The Franconia Formation consists of abundance of scattered fine grains of glauconite (Kolata, 1978). Glauconite is a Fe-rich (Huggett, 2013) iron potassium phyllosilicate mineral characteristic green color and very low weathering resistance. The weathered glauconite mineral grains within the Franconia Formation can be coated with Fe-hydroxide under oxygenated conditions that strongly adsorb Ra (Stackelberg, 2018). 


\section{CHAPTER II: METHODS}

\section{Data}

To model the geology of the area, well logs and geologic data (maps and cross-sections) from previous investigations (Abrams et al., 2015; Kolata, 2005, Kolata et al., 1978; Kolata and Nimz, 2010; Visocky et al., 1985) were used in providing the lithological characteristics of the subsurface in the study area. The Digital Elevation Model (DEM) was downloaded from the Advanced Spaceborne Thermal Emission and Reflection Radiometer (ASTER) website (https://asterweb.jpl.nasa.gov/gdem.asp) and Top of bedrock shapefile were obtained from the Illinois State Geospatial Clearing House (https://clearinghouse.isgs.illinois.edu/). Well logs were downloaded from the Illinois State Geological Survey (ISGS), both the Illinois water wells (ILWATER) and Illinois oil and gas (ILOIL); http://maps.isgs.illinois.edu/ILWATER/, http://maps.isgs.illinois.edu/ILOIL/, respectively (Figure 7). Pumping data was downloaded from the Illinois Groundwater Resources website (https://univofillinois.maps.arcgis.com/apps/webappviewer/index.html?id=53380686a48d43758315505 2fc49d117) and from Rochelle Municipal Utilities.

Table 1: Summary of Data Sources Used for Building the Model.

\begin{tabular}{|c|c|}
\hline Data & Source \\
\hline Illinois Bedrock Topography & Illinois State Geological Survey \\
\hline Digital Elevation Model (DEM) & ASTER \\
\hline Well Data & ILWATER and ILOIL \\
\hline Pumping Data & Illinois State Geological Survey and Rochelle Municipal Utilities \\
\hline Water Level & Illinois State Water Survey \\
\hline Head from Regional Model & Illinois State Water Survey \\
\hline
\end{tabular}




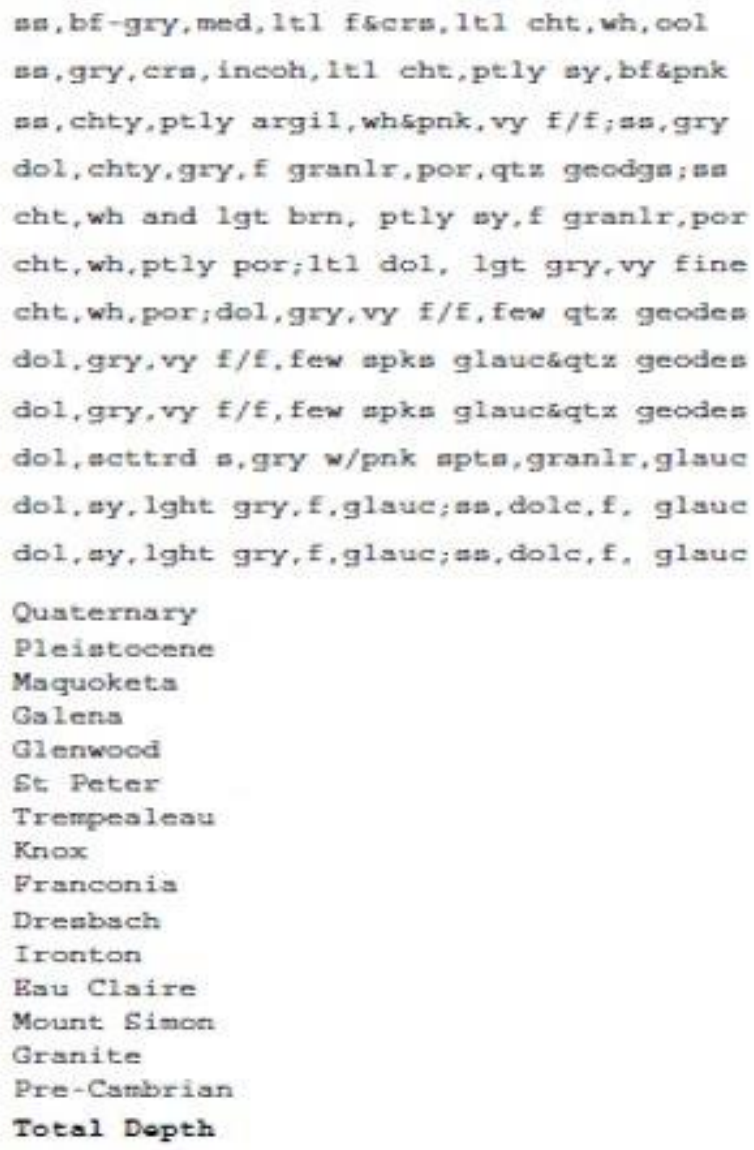

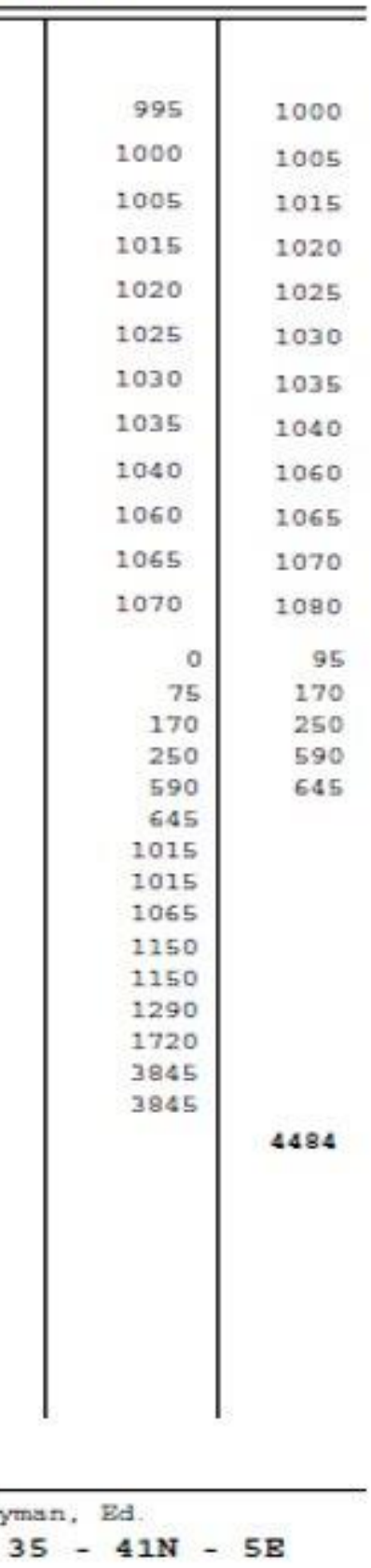

Schulte Paul

COUNTY DeRalb

API $120370067600 \quad 35-41 N-5 B$

Figure 7. Sample of driller's well log. of the units. Six units are identified; these are in order of stratigraphic location from top to bottom: the Maquoketa Shale, Galena Platteville (GP) Carbonate, St. Peter (SP) Sandstone, Potosi-Franconia (PF), 
Ironton Galesville (IG) Sandstone, and Eau Claire (EC) Shale. These units were denoted as GP, SP, PF, IG and EC, which represented top of the Galena Platteville, St. Peter, Potosi-Franconia, Ironton-Galesville and Eau Claire. The top of the Maquoketa Shale was not taken because we obtained the top using the Illinois Bedrock Topography shapefile from the Illinois State Geological Survey. This is because the Maquoketa Shale is eroded within different sections in the study area. Combining the bedrock topography shapefile and the top of the Galena Platteville will accurately model the Maquoketa Shale.

\section{Conceptual Model Development}

Building a conceptual model involves putting together all of the information representing the real system that will later be fine-tuned and turned into a numerical model (Figure 8). Simplification is necessary because a complete reconstruction of the field system is complex and not feasible (Seneviratne, 2007). However, the closer the conceptual model is to the field situation, the more accurate the numerical model framework (Anderson and Woessner, 1992). A conceptual model consists of the hydrostratigraphic units, boundary conditions, sources and sinks: pumping, recharge, flow direction, and water budget. 


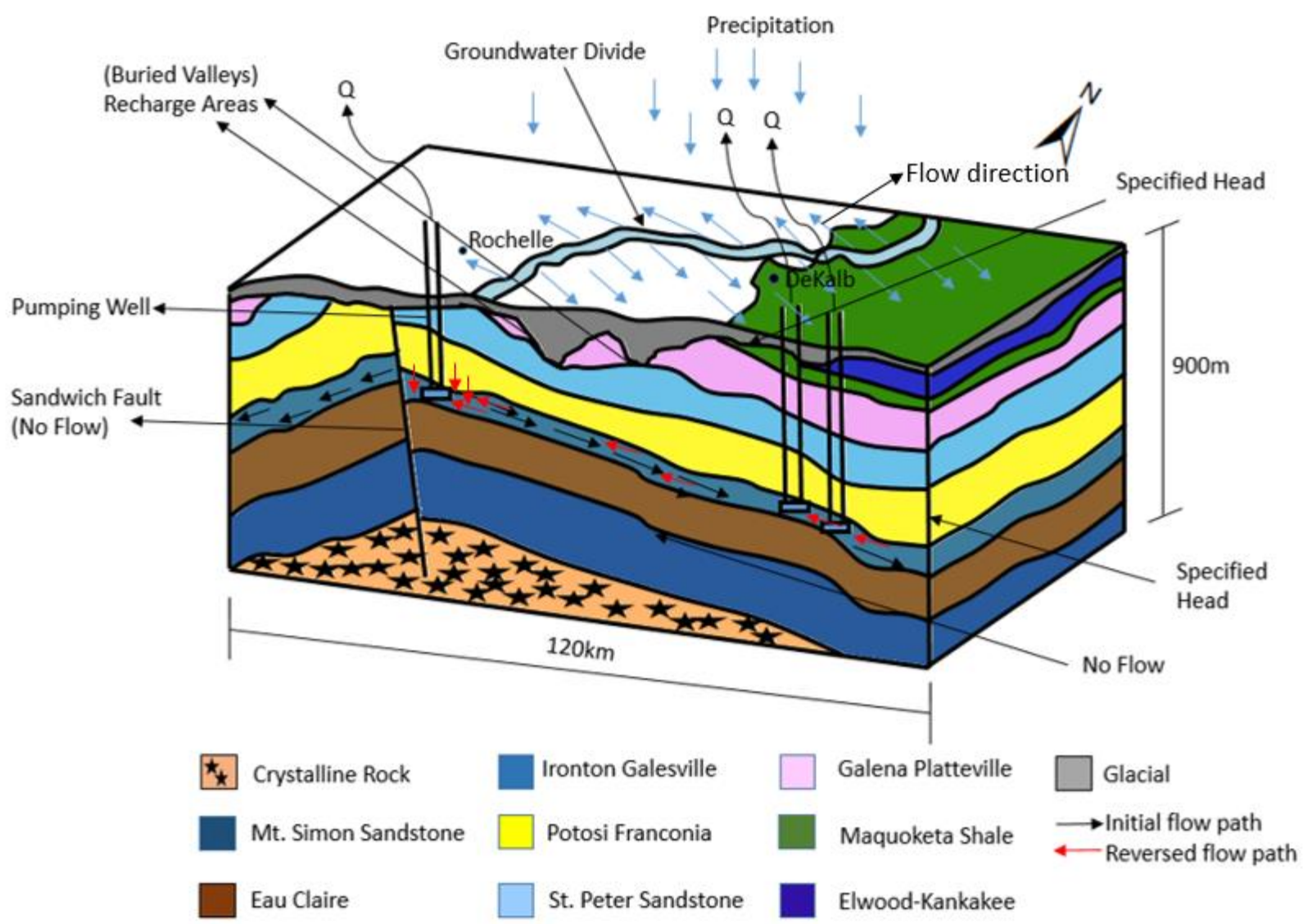

Figure 8. Conceptual Model for the study area. Red arrows represented flow of contaminated waters moving towards Rochelle wellfield. Black arrows represent unaltered flow paths.

\section{Hydrostratigraphic Layers}

Hydrostratigraphic units are part of the main components of a conceptual model. Conventionally, to define the hydrostratigraphic units we use the drillers' logs description such as the lithological descriptions (Figure 7), elevation, stratigraphic location, and most importantly spatial information (latitude and longitude) (Table 2). The latitude and longitude are essential because to get accurate interpolation of the entire layer surface, accurate point datum distribution is necessary. 
Table 2. Sample of How Depth of Stratigraphic Units were Recorded.

\begin{tabular}{|l|l|l|l|l|l|l|l|l|}
\hline No & Id & Lat $(\mathrm{Y})$ & Long $(\mathrm{X})$ & $\mathrm{Z1}$ & $\mathrm{Z2}$ & $\mathrm{Z3}$ & Z4 & Z5 \\
\hline 1 & 120890084600 & 42.0556 & -88.286842 & 275 & 579 & 753 & 1030 & 1216 \\
\hline 2 & 120372186800 & 41.9540 & -88.769207 & 387 & 540 & 835 & 1095 & 1300 \\
\hline 3 & 120370074000 & 41.9328 & -88.738864 & 255 & 570 & 970 & 1125 & 1305 \\
\hline 4 & 120370073900 & 41.9292 & -88.743743 & 210 & 623 & 885 & 1185 & \\
\hline 5 & 120370074100 & 41.9299 & -88.738476 & 180 & 570 & 1010 & 1145 & 1328 \\
\hline 6 & 120370073600 & 41.9365 & -88.770421 & 141 & 530 & 891 & 1105 & \\
\hline 7 & 120370063300 & 41.9315 & -88.778502 & 217 & 556 & 937 & 1127 & \\
\hline 8 & 120370092300 & 41.9925 & -88.696080 & 165 & 530 & 885 & 1020 & 1195 \\
\hline 9 & 120370078500 & 41.9925 & -88.680869 & 210 & 565 & 815 & & \\
\hline 10 & 120372165600 & 41.9734 & -88.722076 & 125 & 560 & 805 & 1116 & 1205 \\
\hline 11 & 120893582900 & 42.0928 & -88.540853 & 242 & 614 & 915 & 1075 & 1227 \\
\hline 12 & 120890089800 & 42.0974 & -88.532574 & 280 & 610 & 820 & 970 & \\
\hline 13 & 120893145900 & 42.0979 & -88.535149 & 263 & 590 & 826 & 980 & 1179 \\
\hline 14 & 120893650500 & 42.0983 & -88.533838 & 248 & 588 & 828 & 1003 & 1203 \\
\hline 15 & 120893616000 & 42.1211 & -88.534908 & 260 & 585 & 825 & 1010 & 1180 \\
\hline 16 & 120893530900 & 42.0965 & -88.480372 & 401 & 732 & 770 & 783 & \\
\hline
\end{tabular}

Note. Empty cells represent wells that didn't get deep down to the top layer of that particular formation.

The depth of each hydrostratigraphic unit was exported from Excel into Notepad ++ for it to be stored as a txt file and later transferred into ArcGIS Map. ArcGIS Map was used to analyze well logs that provided the different unit thickness at different areas in order to provide the variations in the unit layers at different points within the study area. Inverse Distance Weighting (IDW) was used for interpolating the elevation values between the layers. IDW can be simplified to such a process that the estimation of a spatial variable (e.g. Soil property value) at an unmeasured location is calculated by the observation of a number of the measured samples spatially close to the objective location (Zhou and Sha, 2013). The interpolated layers were consistent with previous geologic investigations, such as Abrams et al. (2015), within Ogle and the surrounding counties such as Lee, DeKalb, Kane, Kendall and La Salle. From the interpolated well logs, the different units had a northeastward and southwestward dip from areas such 
as southeast of Ogle, northeast of Lee County and center of DeKalb. The interpolated surfaces were then used for approximating the thickness of the hydrostratigraphic units. The hydrostratigraphic units in northern Illinois dips gently northeastward and southwestward from the axis of a broad, northwest-tosoutheast-trending structural arch known as the Kankakee Arch.

In GMS, MODFLOW 2005 (Harbaugh, 2005) was initialized and a grid system was developed to build the conceptual model. UTM Zone 16 was used as the projection for the conceptual model likewise what was used in ArcMap for the generation of the hydrostratigraphic layers. The imported GIS layers were mapped unto the grid system and later interpolated to represent the 3D hydrostratigraphic model (Figure 9a). The hydrogeological system was conceptualized as a six-layer model with two major aquifers (Figure 9b). Cells within the western portion of the Layer 1 (Maquoketa Shale) were designated inactive because the Maquoketa Shale is eroded within those areas; likewise, some sections of the Galena Platteville layer, which is eroded in sections where the St. Peter crops up. 


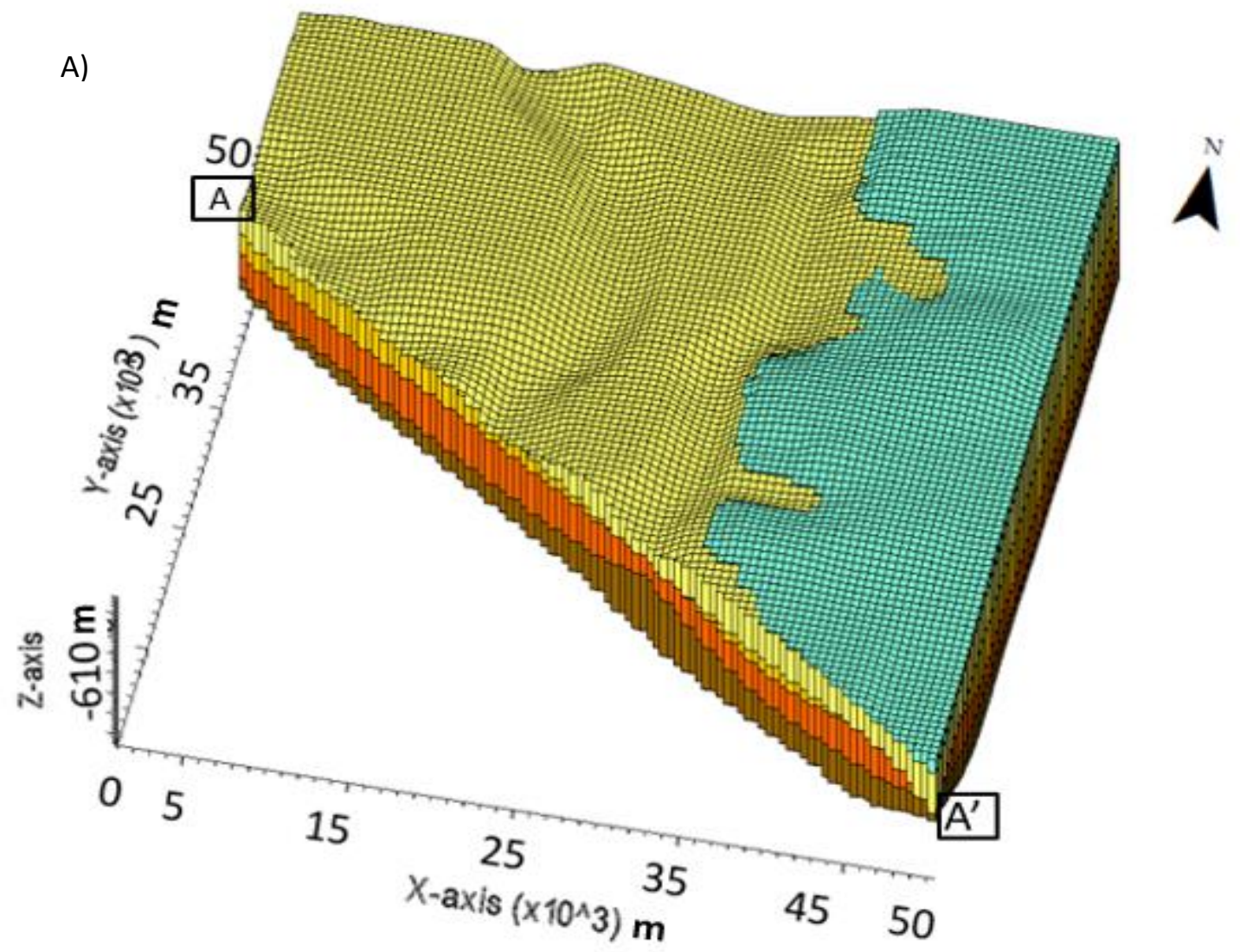

B)

$A^{\prime}$

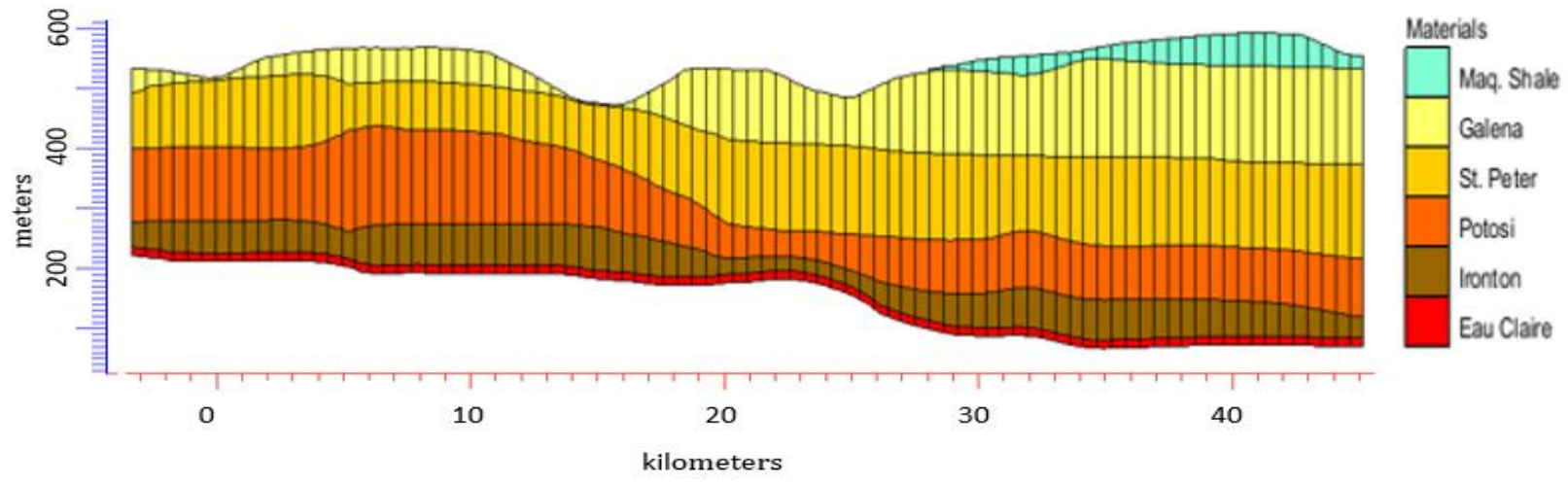

Figure 9. Conceptual Model generated in GMS A) 3D Hydrostratigraphic Model with A-A' used for cross section, B) A-A' cross section representing the 3D hydrostratigraphic model. 


\section{Boundary Conditions}

Accurate description of boundary conditions is an important component of conceptualizing and modeling groundwater systems (Seyoum, 2012). Delineating the boundary for a model requires careful understanding of the physical systems and considerable simplification of the hydrogeologic conditions. Two types of boundaries were defined in this model: no flow boundary and specified head boundary (Figure 10). Southern section of the model was set as a no flow boundary which represent the Sandwich Fault (Abrams et al., 2015; Hadley et al., 2018, Hadley et al., 2016). Hadley et al., (2018) simulated what might be the biggest aquifer test known as the Arsenal Aquifer Test in 1942. Main objective of the simulating the aquifer test was to better characterize the Sandwich Fault Zone. Slopes of drawdown curves were used as calibrating target whiles alternating hydraulic conductivity value. Results showed computed drawdown curves better matched the observed drawdown curves when $\mathrm{K}$ value was very low. Also, specified head boundaries are implemented by fixing head values at the nodes along the boundary, hence specified heads do not change in response to hydrologic stresses (Anderson et al., 2015). Specified head for the model was obtained from the Illinois State Water Surveys regional model. 


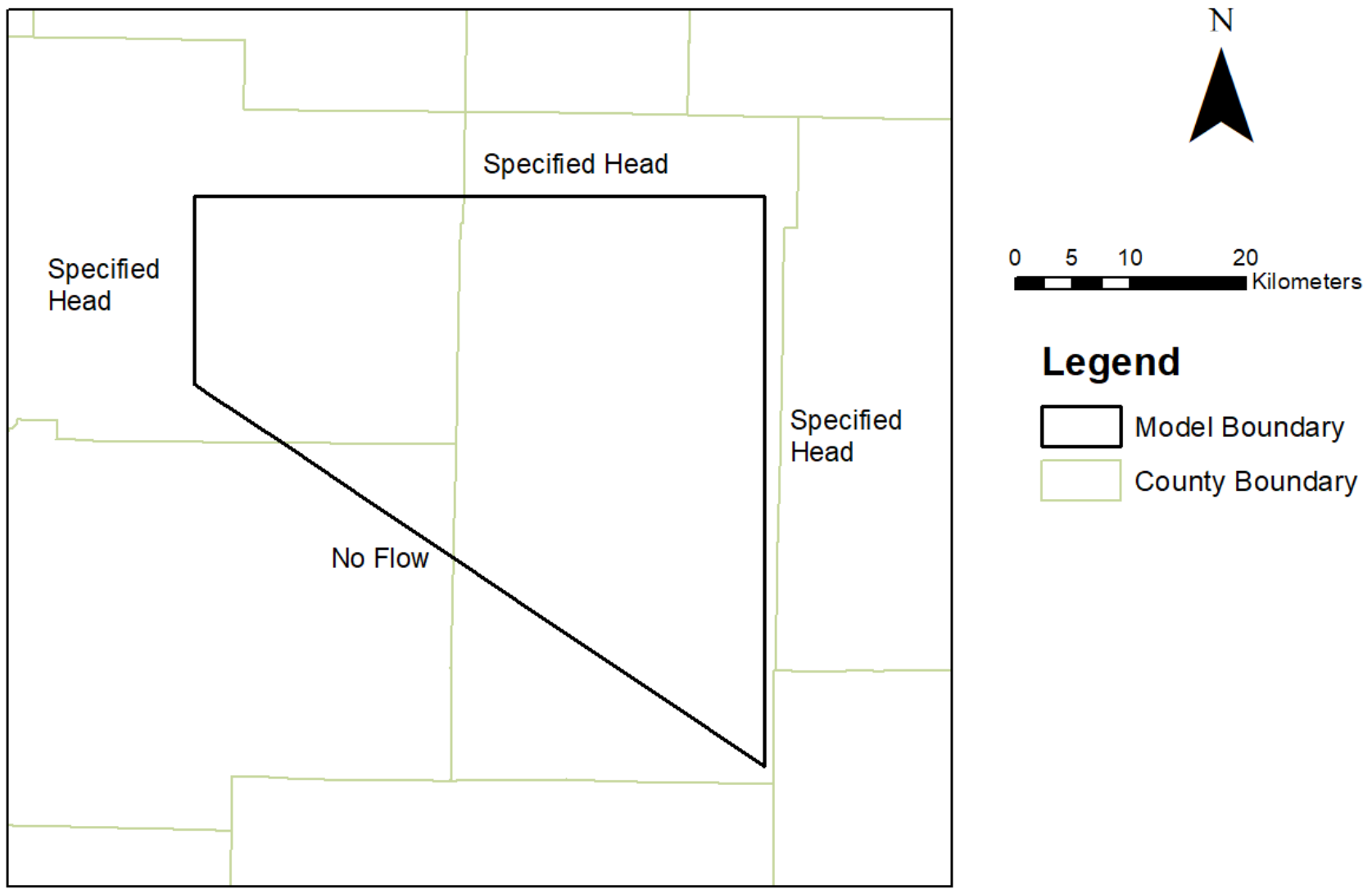

Figure 10. Boundary conditions used for the groundwater flow model. No flow boundary trends along the Sandwich Fault.

\section{Numerical Groundwater Modeling using MODFLOW}

Numerical modeling is an important part of modern hydrogeology due to the fact that it can be used to test certain specific hypothesis, to predict future behavior, or to simply organize available hydrogeological data (Seneviratne, 2007). Groundwater flow models have been used all over the world to help provide detailed characterization of certain key aquifer parameters and general flow pattern and to evaluate regional aquifer resources to make informed management decisions (Yidana et al., 2015). To begin the whole modeling process, a conceptual model was created, which is basically a summation of the knowledge gathered from reports, publications, and data. The next step after the conceptual model design was to develop a partial differential equation (Figure 11), which is based on the properties of the system such as the boundary condition, aquifer properties whether homogenous, heterogeneous, 
isotropic, or anisotropic and also initial conditions. Then, the partial differential equation is solved numerically using the MODFLOW code.

MODFLOW-2005 (Harbaugh, 2005) was used to simulate the groundwater flow pattern and capture zones of the study area. Significant advances in regional flow system analysis were inspired by the application of 3 dimensional (3D) groundwater flow models. Since MODFLOW's release in 1988 by the USGS, MODFLOW has become the global standard worldwide for groundwater flow modeling due to its flexible modular structure, complete coverage of hydrogeological processes, and public domain free availability (Zhou and Li, 2011). The 2005 version of MODFLOW includes certain simulation type such as simulation of saturated-unsaturated flow, groundwater simulation-optimization, irrigation, density dependent flow, parameter optimization, and solute transport (Zhou and Li, 2011). The MODFLOW-2005 is written in the Fortran 90 programming language and programs written in FORTRAN are highly portable (Harbaugh, 2005). Due to its portability, several Windows-based graphic user interfaces for MODFLOW were developed since the 1990. The most widely used are Processing Modflow, Visual Modflow, Groundwater Modeling Systems (GMS), and Groundwater Vista (Zhou and Li, 2011). These graphic user interfaces make the modeling process much easier and allow time saving in analyzing model results (Zhou and $L i, 2011)$. For this study, we used GMS running the MODFLOW code.

The 3D movement of groundwater of constant density through a porous earth material may be described by the partial-differential steady-state equation:

$$
\frac{\partial}{\partial x}\left(K_{x x} \frac{\partial h}{\partial x}\right)+\frac{\partial}{\partial x}\left(K_{y y} \frac{\partial h}{\partial x}\right)+\frac{\partial}{\partial x}\left(K_{z z} \frac{\partial h}{\partial x}\right)+W=0
$$

Where, $\mathrm{Kxx}, \mathrm{Kyy}$, and $\mathrm{Kzz}$ are values of hydraulic conductivity along the $\mathrm{x}, \mathrm{y}$, and $\mathrm{z}$ coordinate axes;

$\mathrm{h}$ is the potentiometric head;

$\mathrm{W}$ is the volumetric flux per unit volume representing sources and/or sinks of water. 
Based on certain assumptions used for creating the model, the general governing equation was modified to represent the hydrogeologic system of the study area. These assumptions are steady-state flow, anisotropic medium and heterogeneous system.

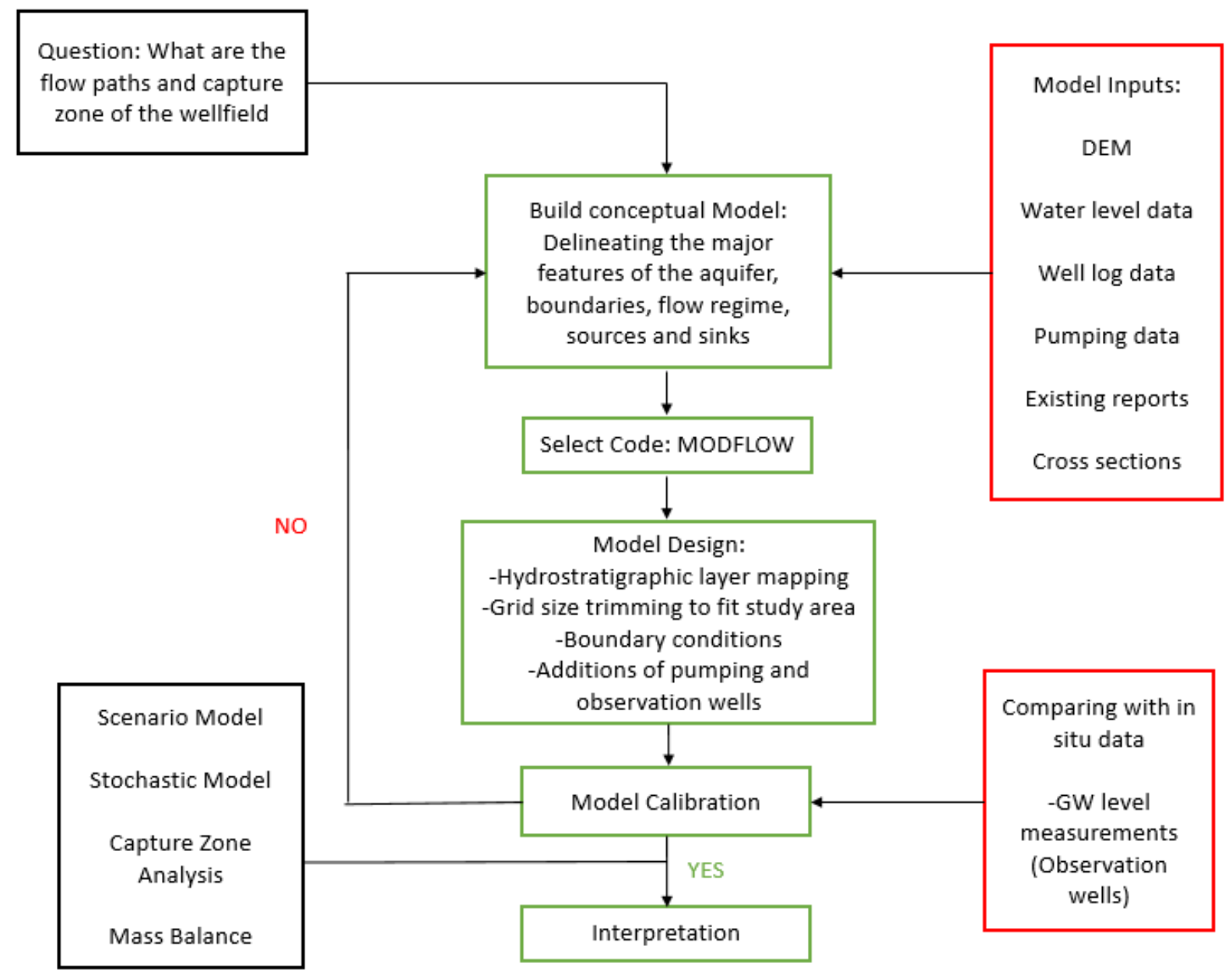

Figure 11. Outline of methodology. Red boxes represent the data to be used in the modeling process,

while green represents the steps.

\section{Numerical Model Design}

The three-dimensional conceptual model was converted into the numerical model using GMS, which is an interface that supports MODFLOW (Harbaugh, 2005). The numerical model has a cell size of 500 $\mathrm{m} \times 500 \mathrm{~m}$, with total number of 168000 cells and 6 different layers representing the different 
hydrostratigraphic units. The model has width of $47000 \mathrm{~m}$ in the $\mathrm{x}$-dimension and length of $50000 \mathrm{~m}$ in the $y$-dimension and a depth of $610 \mathrm{~m}$ in the z-dimension. The Maquoketa Shale, Galena-Platteville, St. Peter, Potosi Franconia, Ironton- Galesville and Eau Claire had thickness of 70 m, 160 m, 140 m, 130 m, $90 \mathrm{~m}$, and $20 \mathrm{~m}$ respectively. Coverages files were created to represent the sources and sinks such as recharge and pumping and aquifer parameters such as hydraulic conductivity and anisotropy. Observational hydraulic head coverage was also created, which was later mapped to MODFLOW to represent the observed head and used during calibration. Initial values of hydraulic conductivity were assigned based on hydraulic conductivity values obtained from Abrams et. al., (2018).

Groundwater recharge was applied vertically to the highest active cells, which might be layer 1, 2 or 3 depending on the location within the model domain. A single recharge coverage was created with recharge rate of $0.00041 \mathrm{~m} / \mathrm{d}$. This value was calculated to fall within the typical recharge rate to the glacial system for the study area that is between $0.00001 \mathrm{~m} / \mathrm{d}$ to $0.0009 \mathrm{~m} / \mathrm{d}$ (Greer, 2009). Subsequently, two recharge zones were created based on the locations where the Maquoketa Shale terminates in the study area (Figure 1). The glacial sediments were not included as a hydrostratigraphic unit in the model because of the lack of specified head boundary to represent the entire glacial aquifer. The glacial sediments within the study area is very heterogenous (Abrams, 2018) therefore having specified head for just the glacial layer was difficult. Moreover, the only sandstone aquifer that was only actively recharged was the St. Peter (Mannix et al., 2018) which was occurring within the bedrock valleys within the model domain. Therefore, two recharge zone were created. Recharge was directly applied to the top highest active cell be it Maquoketa Shale, Galena Platteville Carbonate or the St. Peter Sandstone. This was done so that areas where the St. Peter crops up (regions like the bedrock valleys) which is the recharge area can receive recharge although the glacial layer was absent. 


\section{Model Parameters}

An important parameter needed within the model was the hydraulic conductivity (K). Hydraulic conductivity is the measure of the ease with which a medium transmit water, higher $\mathrm{K}$ materials transmits water more easily than lower K materials (Fitts, 2013). The bedrock units near the surface have high $\mathrm{K}$ because of weathering and dissolution occurring, which allows for increased horizontal and vertical permeability (Abrams et. al, 2018). Hydraulic conductivity zones for different layers were delineated based on the occurrence of different lithology within a particular layer. The hydraulic conductivity zones were delineated using georeferenced bedrock lithology maps using ArcMap from Abrams et al., (2018). For example, such as Ogle, and DeKalb have areas were the St. Peter Sandstone crops out to the surface and also certain areas where the Maquoketa shale is present. These zones were then captured as different polygons using ArcMap and then exported into GMS where different horizontal and vertical hydraulic conductivity values were entered for each polygon to reflect the variations in lithology. Initial model parameters (Table 3) were inputted into the model for initial models runs so as to stabilize the model and become familiar with it.

Table 3. Summary of Initial Model Parameter Values.

\begin{tabular}{|c|c|c|c|c|}
\hline Model layer & Unit & $\begin{array}{c}\text { Initial Kh } \\
(\mathrm{m} / \mathrm{d})\end{array}$ & $\begin{array}{c}\text { Anisotropy } \\
\left(\mathrm{K}_{\mathrm{h}} / \mathrm{K}_{\mathrm{v}}\right)\end{array}$ & Aquifer Type \\
\hline 1 & Maquoketa Shale & 0.00001 & 1 & Confining layer \\
\hline 2 & Galena Platteville & 0.152 & 58 & Semi confining layer \\
\hline 3 & St. Peter Sandstone & 1.524 & 8.3 & Aquifer \\
\hline 4 & Potosi Franconia & 0.152 & 58 & Semi confining layer \\
\hline 5 & Ironton- Galesville & 1.524 & 16.6 & Aquifer \\
\hline 6 & Eau Claire & 0.00001 & 1 & Confining layer \\
\hline
\end{tabular}

Note. Values for layer 2,3,4, and 5 were obtained from Abrams et al., 2018. Values for layer 1 and 5 were from conventional $\mathrm{K}$ values for shale. 


\section{Calibration}

In order to reproduce the actual groundwater flow condition, the model was calibrated using observed hydraulic head data (Figure 12) spread across different regions within the model domain (Figure 13) and pseudo observational wells created from head values from IGWFM. To allow for better analysis and prediction, the model was calibrated in order for the simulated or computed head values to closely match with the observed head values (Figure 12).

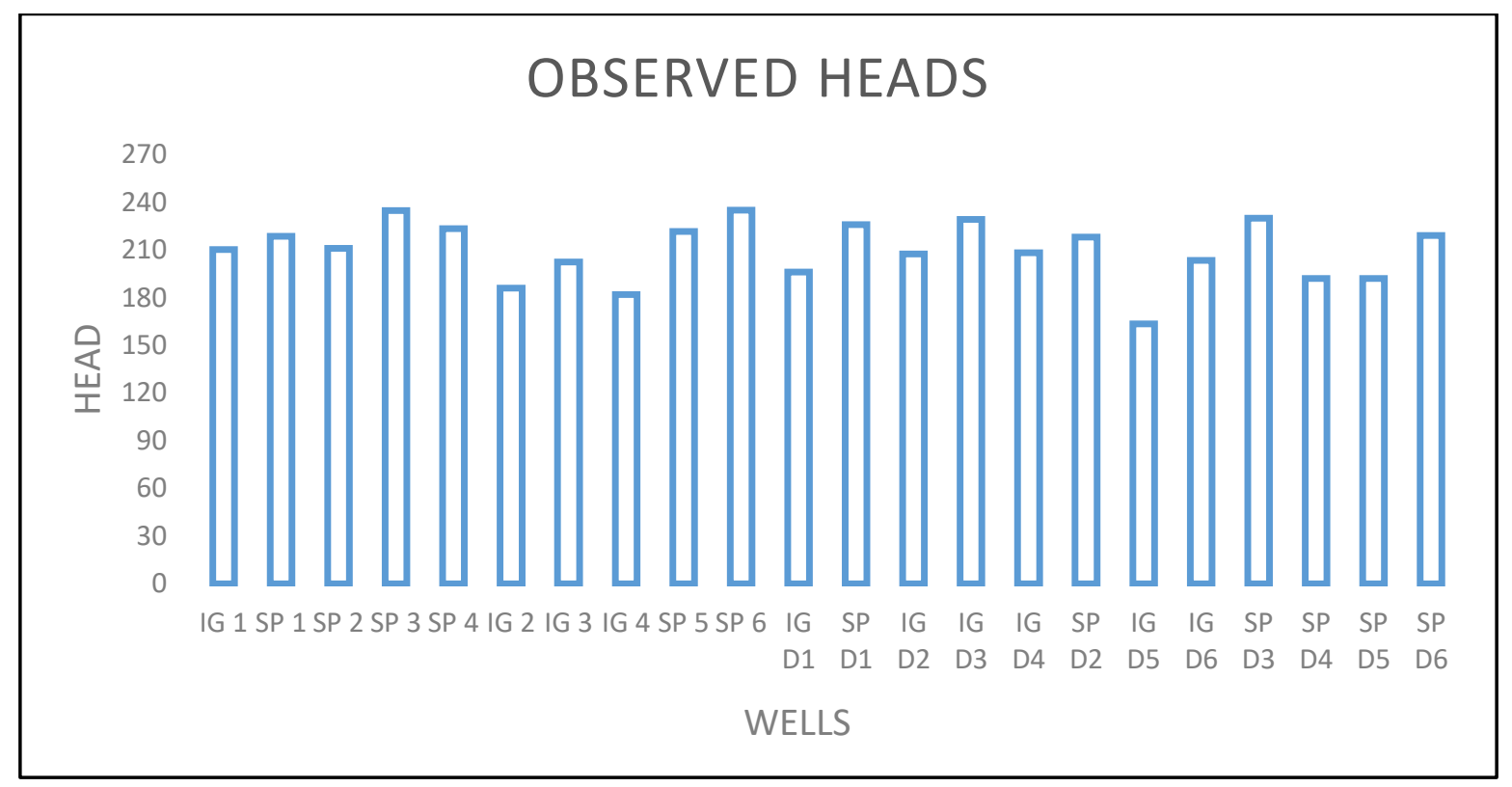

Figure 12. Observed head values for observation wells used for calibration. IG represent Ironton-

Galesville wells while SP stands for St. Peter. D represents dummy wells in respective aquifers. Spatial location of wells can be found in Figure 13 below. 


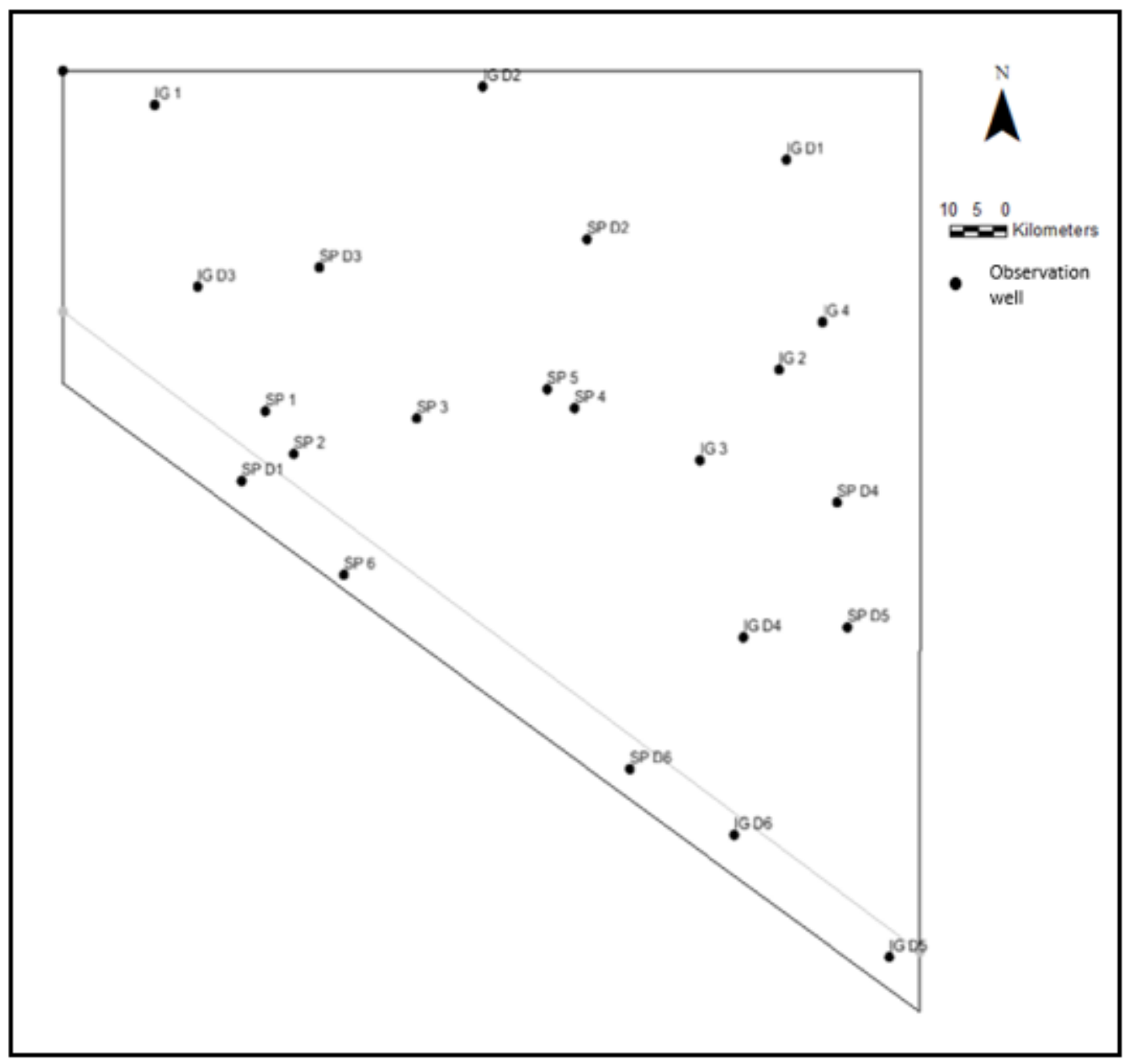

Figure 13. Location of observation wells used for calibration. Heads for the wells can be viewed from

Figure 12. The line parallel to the southwest boundary represents the Sandwich Fault zone boundary Model calibration can be viewed as an important component when trying to develop a groundwater model (Zhou, 2011). Due to certain limiting factors such as in depth understanding of the field conditions, lack of data, uncertainty arising from conceptual model, boundary conditions and parameter distribution of dominant stresses results in plausible model error (Zhou, 2011). Therefore, during the calibration process, components connected to the model were adjusted to make sure the computed head values are mimicking the observed or field head values. The model was calibrated by using the trial and error process otherwise referred to as manual calibration (Figure 14). Input 
parameter, specifically horizontal hydraulic conductivity $\left(\mathrm{K}_{\mathrm{h}}\right)$, anisotropy; which is basically a ratio of horizontal hydraulic conductivity $\left(\mathrm{K}_{\mathrm{h}}\right)$ and vertical hydraulic conductivity $\left(\mathrm{K}_{\mathrm{v}}\right)$, recharge and pumping were altered during several model runs.

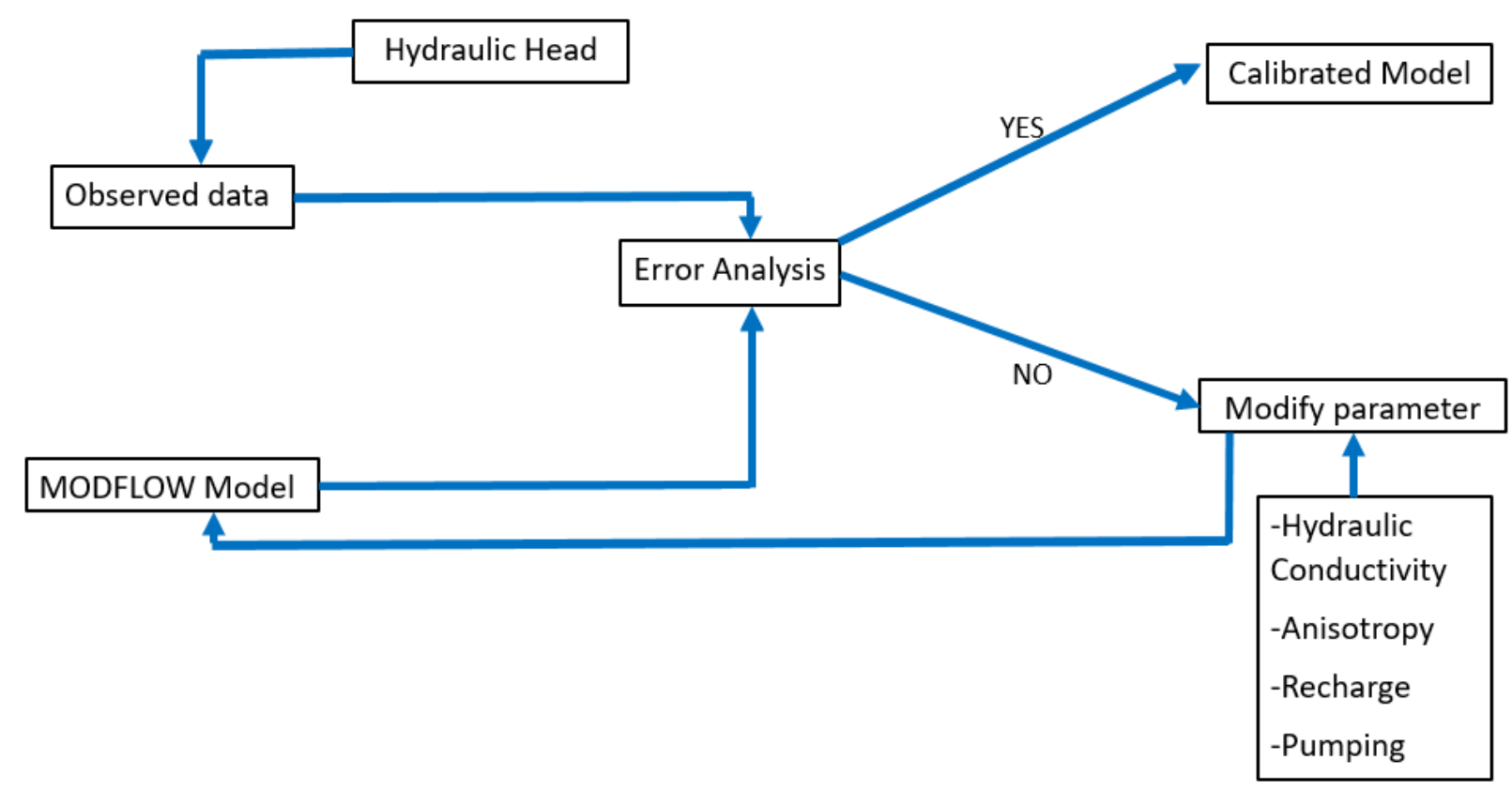

Figure 14. Flowchart explaining the trial and error process used for calibration.

\section{Calibration Targets}

If we have an observed value at an observation point, we are able to find the calibration error at that point using the calibration target. Magnitude, direction, whether negative or positive and spatial distribution of the calibration error can be obtained by viewing a set of calibration targets (Figure 15). Weaver et al. (1991) calibrated their model using water levels, the primary type of calibration target employed for the model was in-situ water level (hydraulic head). However, the number of in-situ water level for the calibrated year 1980 wasn't enough and spatially convincing. To overcome this, pseudo (dummy) observation wells were created at different location within the model domain. Heads for the pseudo wells were obtained from the calibrated Illinois Groundwater Flow Model (IGWFM). In setting up the calibration targets for the model, less weight was assigned to the pseudo wells as compared to the in- 
situ water level wells. The observation head confidence for the in-situ water level wells was $95 \%$ and that of the pseudo wells was $25 \%$. There were 22 observation wells used for calibration, 10 in-situ groundwater level wells and 12 pseudo observation wells. The attributes of calibration target is show below (Figure 15). The goal of this study was to calibrate the model with an average calibration interval of $\pm 2 \mathrm{~m}$. The red box can either be above or below the observed value depending on whether the model is overestimating or underestimating the head at that particular location. As shown in Figure 16, If the calibration target is filled with red, it means the error is above the interval set for calibration, which in this case $\pm 2 \mathrm{~m}$. If the computed head falls within 1-2 m, the calibration target turns yellow and green if it falls within less than $1 \mathrm{~m}$

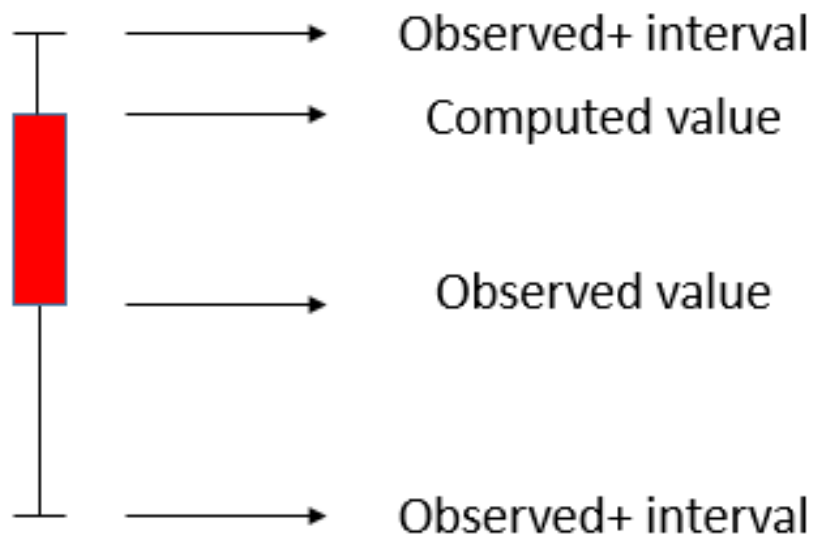

Figure 15. Components of calibration target. 


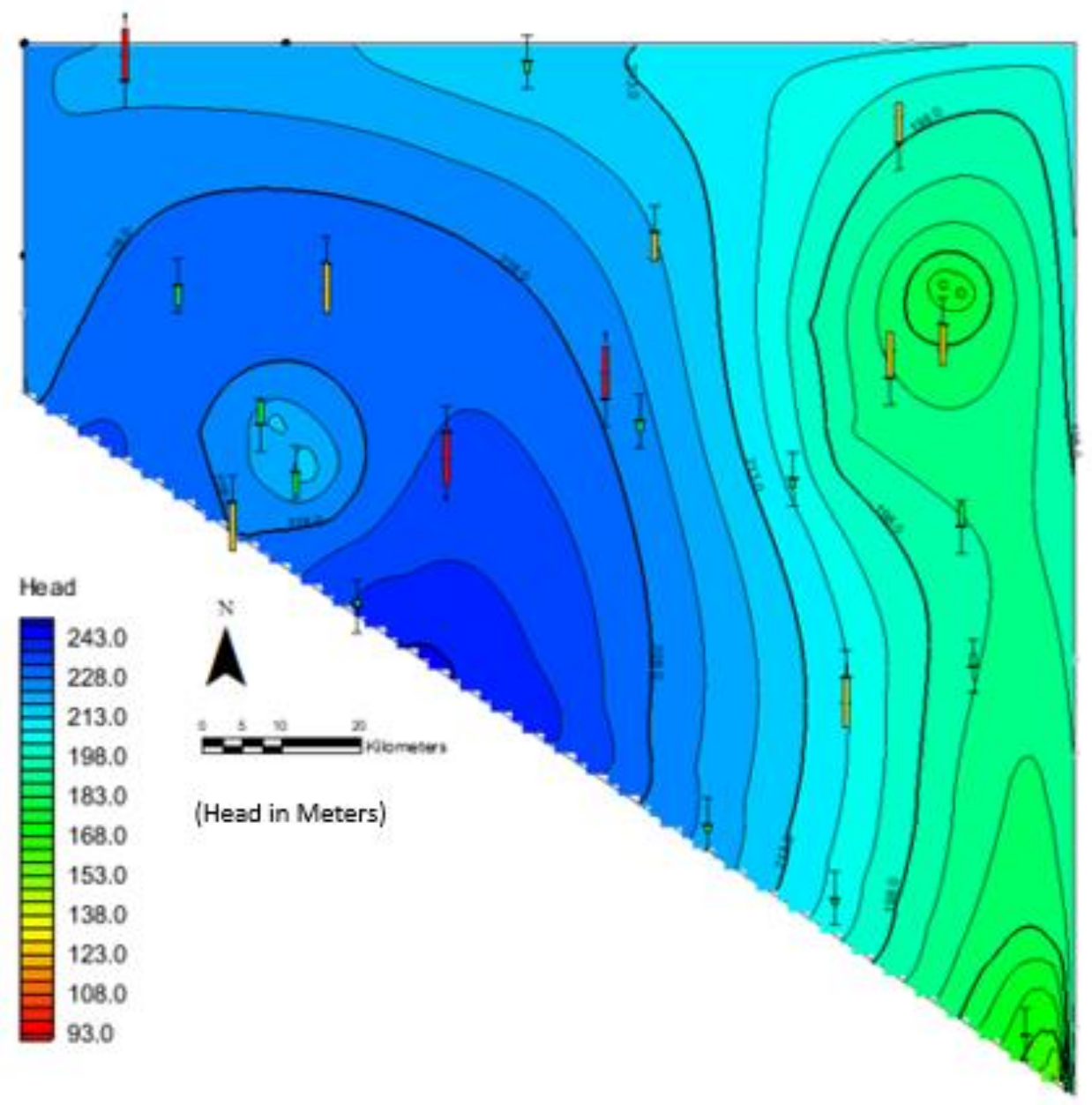

Figure 16. Spatial distribution of calibration targets for the calibrated model. Contour lines and color variations represents the hydraulic head distribution for the calibrated model.

\section{Calibration Statistics}

Evaluation of the trial and error process was done using different statistical measures such as the Root Mean Square Error (RMSE), Mean Error and Mean Absolute Error to evaluate the accuracy of the simulated model. Most importantly, the RMSE was used. The RMSE error is the square root of the average of the squared difference between observed head (ho) and the computed head (hc):

$$
\mathrm{RMSE}=\left[\frac{1}{n} \sum_{1}^{n}(h o-h c)_{i}^{2}\right]^{0.5}
$$

Where $\mathrm{n}$ can be referred to as the number of observations. 
The trial and error process was done until the different statistical measures were reduced to the target value (Figure 17). It was imperative to keep track of the trend in errors as new solutions were simulated after the model parameters were changed so as to know which parameters the model is sensitive to and what to change before re-running the model. The model was calibrated with an RMS of $1.74 \mathrm{~m}$ (Table 4). The final calibrated model had an $\mathrm{R}^{2}$ of 0.991 , which means the observed vs the simulated head had very good correlation (Figure 18).

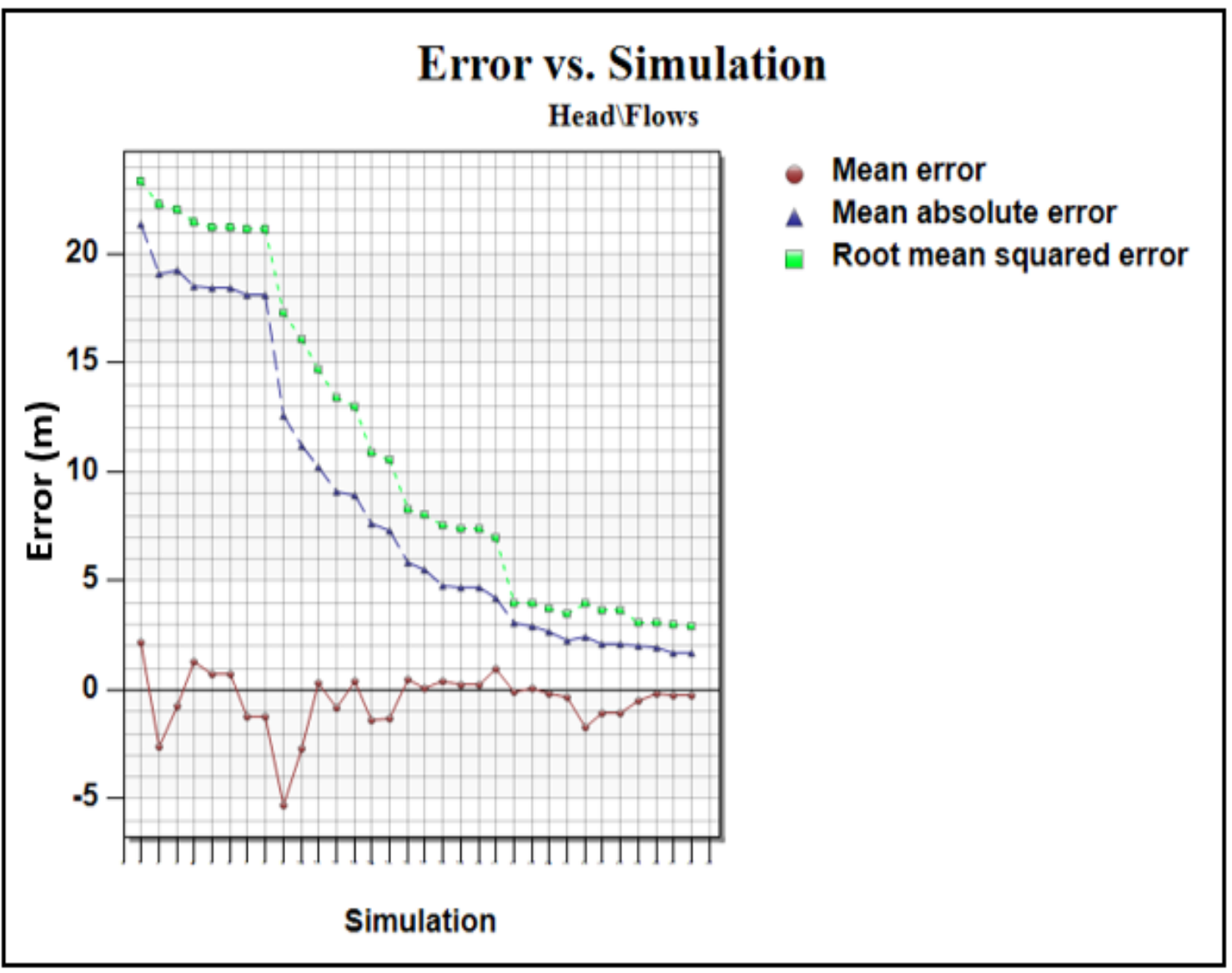

Figure 17. Plot of error vs simulation showing the calibration progress for the trial and error phase of calibration. 
Table 4. Calibration Statistics for Final Manual Calibrated Model.

\begin{tabular}{|c|c|}
\hline Item & Value \\
\hline Mean Residual (m) & 0.07 \\
\hline Mean Absolute Residual (Head) (m) & 1.29 \\
\hline Root Mean Squared Residual (Head) (m) & 1.74 \\
\hline Mean Weighted Residual (Head+ Flow) & -0.27 \\
\hline Mean Absolute Weighted Residual (Head+ Flow) & 1.7 \\
\hline Root Mean Squared Weighted Residual (Head+ Flow) & 3 \\
\hline Sum of Squared Weighted Residual (Head+ Flow) & 197.81 \\
\hline
\end{tabular}

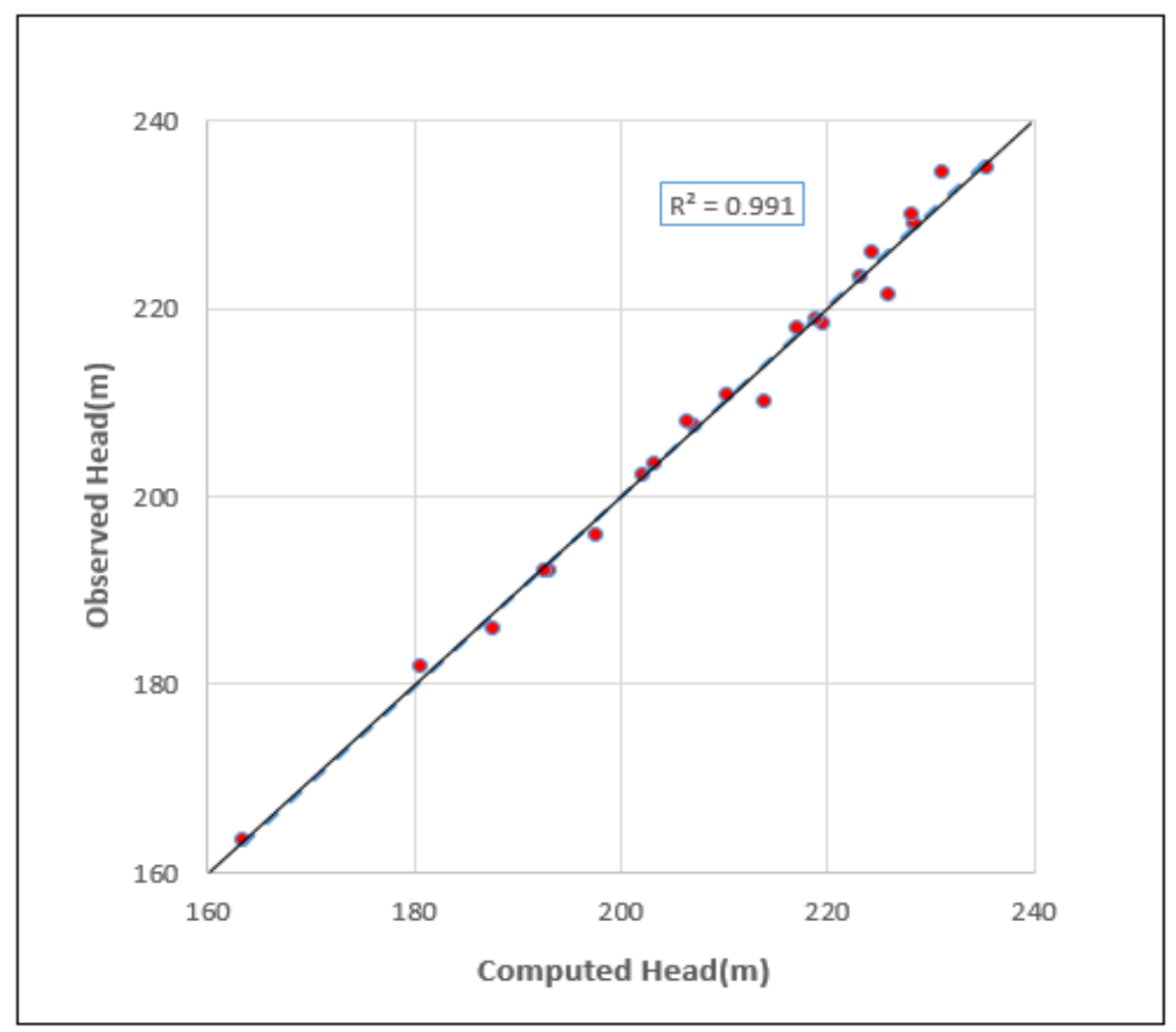

Figure 18. Correlation between observed and computed heads. Blue dotted line represents the 1:1 correlation between the observed and the computed heads. Points that plots close to the $1: 1$ line represents low error and vice versa for points plotted far from the 1:1 line. 


\section{Automatic Calibration}

After manually calibrating the model for a while to increase the goodness of fit, automatic calibration was introduced to refine the parameters obtained from the manual calibration. The automatic calibration used in this case was PEST. PEST is designed to allow for parameter estimation of any model (Kumar, 2015). PEST was supplied with the initial parameter values to work with based on the parameter values obtained from the manual calibration process (Table 5,6, and 7). PEST executes MODFLOW with the given initial parameter values and outputs of MODFLOW are then compared with a given set of observed data and estimate the objective function, which PEST starts minimizing by adjusting the parameters (Seneviratne, 2007). A list of parameters was adjusted using the zonal PEST approach instead of the pilot point's method.

The zonal approach was used based on geologic understanding of the study area. Fault zones are important features that dictate flow within parts of northern Illinois (Abrams et. al, 2018) specifically the study area. One of the most prominent geologic feature is the Sandwich Fault Zone, which was used as the southern boundary of the model domain. The Sandwich Fault Zone vertically displaces the Cambrian-Ordovician sandstone aquifers, either partially or completely (Abrams et. al, 2018). The net effect of the Fault Zone is a decrease in the horizontal permeability due to the potential development of deformation bands, increased cementation, and offset of high permeability zone (Abram et. al, 2018). The difference in permeability allowed for the creation of zones that was properly calibrated so as to mimic the field conditions (Figure 19a). Recharge zone (Figure 19b) was also created based on the presence or absence of the Maquoketa Shale. Recharge zones were created for 1) The part of the study area covered by the Maquoketa Shale that receives less recharge as compared to 2) the areas where the Maquoketa Shale is missing and the top bedrock surface is either the Galena- Platteville Formation or the St. Peter Sandstone, and the recharge was properly calibrated using the Zonal method. 
Horizontal Hydraulic Conductivity and Anisotropy
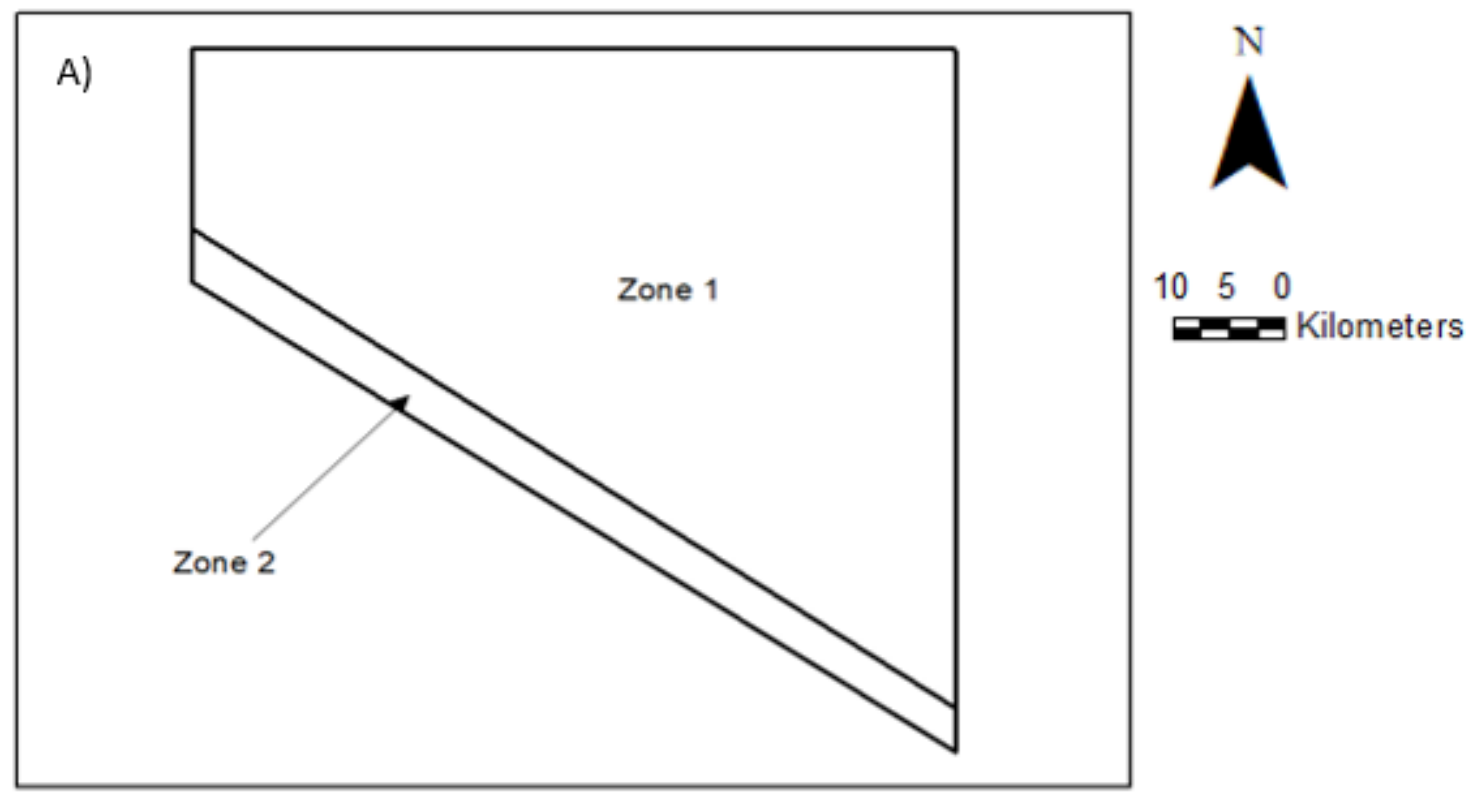

Recharge

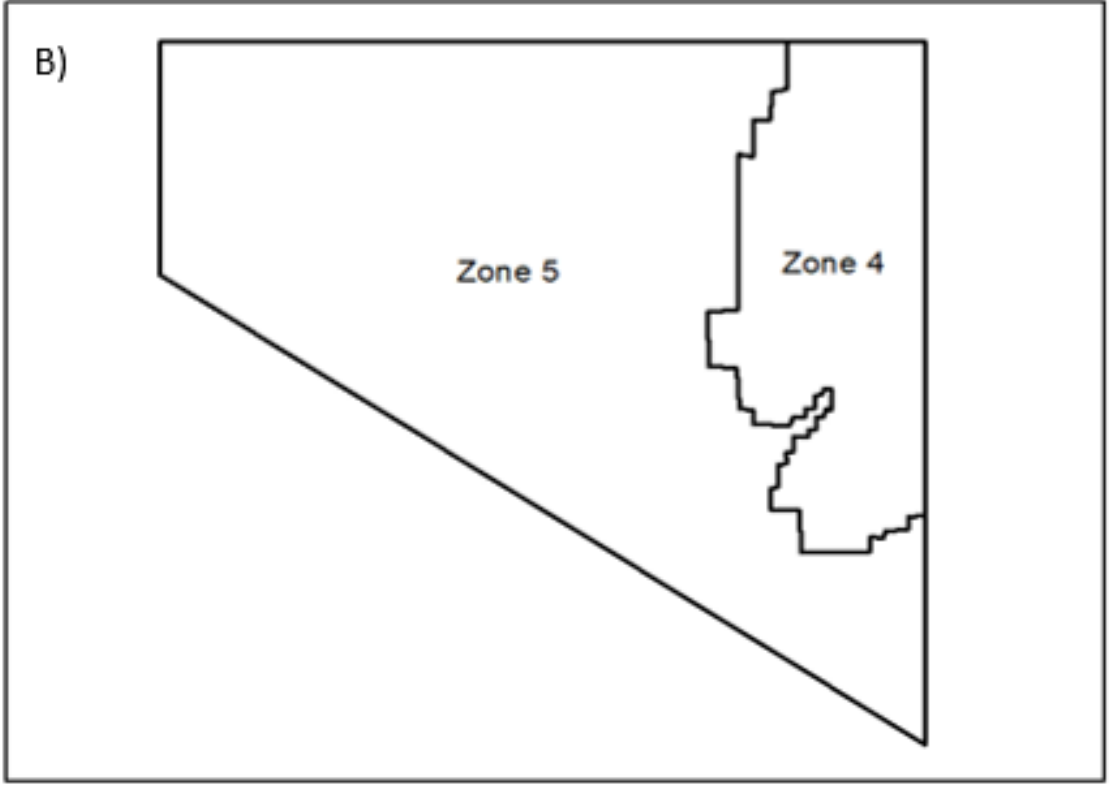

Figure 19. Map showing zones used in PEST Calibration A) K and anisotropy zone map for both St. Peter and Ironton-Galesville aquifer, B) Recharge zone map. Zone 1 for area outside Fault Zone and Zone 2 represents Fault Zone area. Zone 4 represents recharge area where the Maquoketa Shale is present and Zone 5 for area where the Maquoketa Shale is absent. 


\section{PEST Calibration Statistics}

After using PEST, the parameters obtained for the various zones were more in line with what we expected for the study area. The best error statistics obtained from the manual calibration had hydraulic conductivity for the Fault Zone higher than the surrounding area, which didn't align with previous information gathered for the study area. To overcome this, the PEST calibration process had range for minimum and maximum values reduced considering the parameter values from the manual calibration so as to result in realistic values where hydraulic conductivity for the fault zone being lower than the surrounding area. Parameter values were then generated for the zones with less error after the PEST simulation (Table 5,6 and 7).

Table 5. Calibrated Parameter Values for St. Peter Before and After PEST.

\begin{tabular}{|l|l|l|l|l|}
\hline Parameter & \multicolumn{2}{|l|}{ Zone 1 } & \multicolumn{2}{l|}{} \\
\hline & Bone 2 & \\
\hline & Before & PEST & Before & PEST \\
\hline Horizontal K & 0.8830478 & 0.859598 & 0.000418 & 0.2297 \\
\hline Anisotropy & 0.01 & 0.01 & 0.0005 & 0.0005 \\
\hline
\end{tabular}

Table 6. Calibrated Parameter Values for Ironton-Galesville Before and After PEST.

\begin{tabular}{|l|l|l|l|l|}
\hline Parameter & \multicolumn{2}{|l|}{ Zone 1 } & \multicolumn{2}{l|}{} \\
\hline & Before & PEST & Before & PEST \\
\hline Horizontal K & 0.8013 & 1.2 & 2.651 & 0.5718 \\
\hline Anisotropy & 0.0008 & 0.0008 & 0.1 & 0.1 \\
\hline
\end{tabular}

Table 7. Calibrated Recharge Values Before and After PEST.

\begin{tabular}{|c|c|c|c|c|}
\hline \multirow[t]{2}{*}{ Parameter } & \multicolumn{2}{|l|}{ Zone 4} & \multicolumn{2}{|l|}{ Zone 5} \\
\hline & Before & PEST & Before & PEST \\
\hline Recharge & $3.3 \times 10^{-5}$ & $3.3 \times 10^{-5}$ & $3.3 \times 10^{-5}$ & $2.0 \times 10^{-7}$ \\
\hline
\end{tabular}




\section{Sensitivity Analysis}

Sensitivity analysis was determined for the model parameter during the automatic calibration phase. In addition to computing the optimal parameter values, PEST will compute the sensitivities of each parameter. The sensitivity analysis was done in an automatic way instead of the conventional manual process where model parameters are changed to view which parameters resulted in a big change in model results. Information concerning the parameter sensitivity is printed to the SEN file at each parameter estimation iteration and then plotted using the Plot Wizard option in GMS.

\section{Effect of Boundary Conditions}

Boundary conditions influence the outcome of steady-state numerical groundwater model solution, thus, the effect of the boundary conditions on the model results were analyzed. Specified boundary heads do not change in response to hydrologic stresses (Anderson et al., 2015) like pumping. The appropriateness of a specified head boundary can be tested by evaluating the flow from the boundary and the change in flow due to the change in head value (Reilly and Harbaugh, 1996). To assess the effect of specified head boundary on model outcomes such as scenarios and capture zone analysis, the specified head values for the nodes were reduced by $17 \mathrm{~m}$ and the model was rerun to compare the results (Figure 20). If the change in the specified head boundary causes an appreciable change in the model results (e.g. how the cone of depression looks) then the boundary has a strong effect on the model simulation. In this case a particular cell B was selected to see the effect of change in boundary condition on the cone of depression within the Rochelle.

For the initial specified head values for the model boundary the head value for cell B was 131.7 $\mathrm{m}$ and the head value for cell $\mathrm{B}$ after lowering the specified head boundary was $128.57 \mathrm{~m}$. The change in the specified head values will cause a change in head values for cell B. However, there wasn't a difference in model results, for example the shapes of cone of depressions, capture zones, and groundwater divide. 


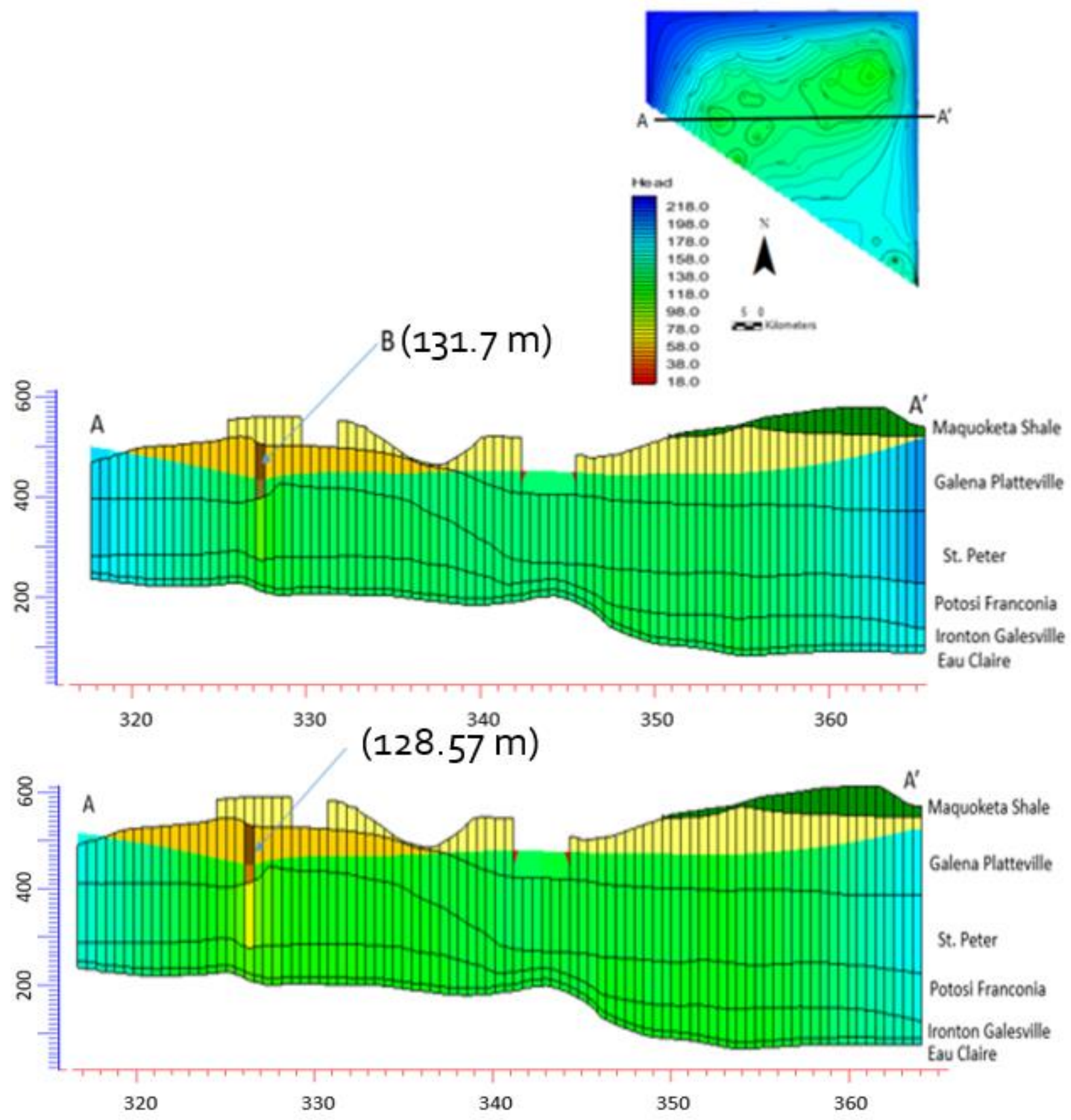

Figure 20. Change in boundary condition A) A-A' cross section showing head distribution for initial specified head, B) A-A' Cross section A-A' showing head distribution after reducing specified head boundary conditions. B represents the cell that was selected to assess the effect of change of boundary condition. 


\section{Scenario Analysis}

To answer the first research question, Steady- state simulations can be used to analyze the natural flow systems as well as new equilibrium conditions that have been attained (Fenke et. al., 1987). The calibrated steady sate model was used to simulate different pumping scenarios to assess which pumping condition resulted in the displacement of the groundwater divide close to Rochelle. Four different scenarios were simulated for the analysis. Scenario 1 represents the lowest withdrawal rates whiles Scenario 4 represents the highest withdrawal rates. Scenario 2 and 3 represents the intermediate withdrawal rates where Scenario 2 is higher than Scenario 1 and less than Scenario 3. To minimize the effect of dry cells in model convergence during the scenario analysis, MODFLOW 2005 (Harbaugh, 2005) was switched to MODFLOW -NWT. This is because during the scenario analysis the potentiometric surfaces sometimes falls below the bottom elevation of the aquifer due to abstraction and this causes dry cells, which results in non-convergence of the solution. This problem is difficult to solve using MODFLOW-2005 solvers that rely on the Picard-linearization method because the aquifer- bottom altitude varies across the domain, and regions of the aquifer becomes dry during low recharge rates (Niswonger et al., 2011).

To have a standard to work with, a withdrawal map from the Illinois State Water Survey was georeferenced in Arc Map and edited to create a withdrawal map for the study area (Figure 21) with different withdrawal values (Table 8). From the withdrawal map, three significant pumping centers are visible, these are the Rochelle area on the left side of the map, DeKalb pumping center which is the major pumping center amongst the three, and the southeastern center (which is the least in terms of pumping). 


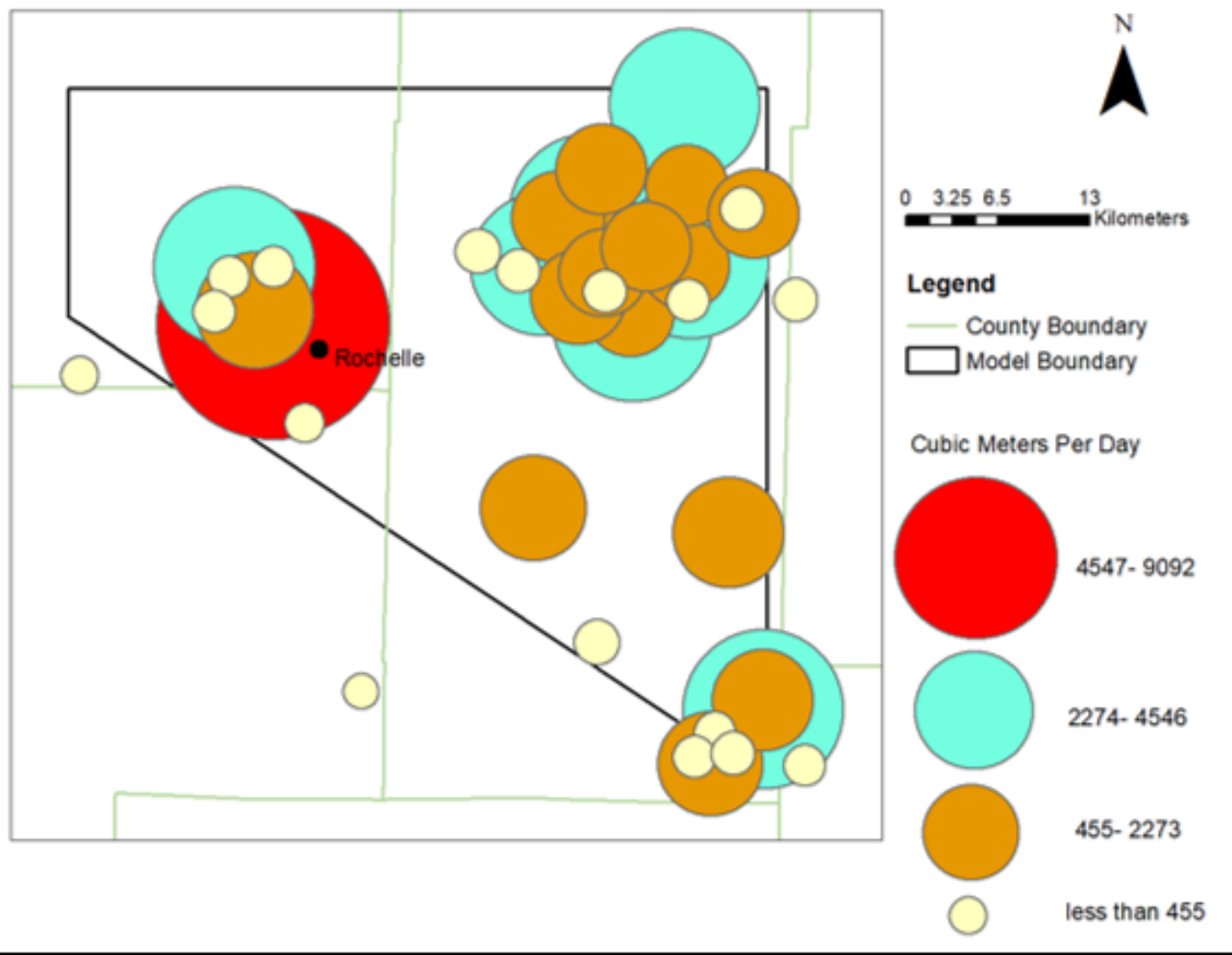

Figure 21. Withdrawal map for year 2013 for the study area, modified from Abrams et al. (2018).

Colored circles represents the magnitude of pumping in the area and not well location.

Table 8. Withdrawal Rates for the Three Different Pumping Centers.

\begin{tabular}{|c|c|}
\hline Pumping Centers & Total Withdrawal $\left(\mathrm{m}^{3} / \mathrm{d}\right)$ \\
\hline Rochelle Area & 11592 \\
\hline DeKalb & 30,004 \\
\hline Southeastern Centre & 7728 \\
\hline
\end{tabular}

Note. These values represent the maximum pumping for the three pumping centers in the model as obtained from Figure 20. 


\section{Stochastic Modeling}

Uncertainty is always associated with groundwater models. Uncertainty can arise from errors in the conceptual model or data and parameters uncertainty associated with various components of the model. Some of the model parameters like hydraulic conductivity and recharge are particularly prone to uncertainty. Hydraulic conductivity is the most influential parameter in groundwater simulations and is the most uncertain parameter in numerous groundwater models (Mahmud et al., 2015). However, stochastic modeling is an approach that helps to reduce the uncertainty. Stochastic analysis allows for a quantitative evaluation of the effects of variability and thereby provides a means of addressing uncertainty in the resultant head and flow that is caused by uncertainty in the model parameters (Lin et al., 2017). With the stochastic approach, a set of probable models were generated in GMS using MODFLOW. Each model is then used to make a prediction or simulate a given scenario based on a particular parameter and the results are used to estimate a probability of risk that a certain outcome will occur. GMS provides two different types of parameter randomization techniques, which are the Random Sampling and the Latin Hypercube. We used the Random Sampling technique since the parameter can be specified as log transformed, which is typically the case for hydraulic conductivity. With the Random Sampling method, a mean, a standard deviation, a minimum value, and a maximum value were specified for each parameter. For each simulation, a random number was generated for each parameter (hydraulic conductivity and recharge) according to the specified distribution using the mean, standard deviation, maximum and minimum.

\section{Capture Zone}

The capture zone is defined as the zone of groundwater that is eventually pumped out by the well (Fitts, 2013) or a 2-dimensional surface that includes the subarea of the total areal recharge providing groundwater to a pumped well (Landmeyer, 1994). Determining the contributing area to a well, or the land surface from which aquifer is recharge is captured by the well is important part of 
determining the well vulnerability (Ayotte, 2011). The shape and extension of the capture zone is defined by the geometry and hydrogeologic properties of the aquifer and the imposing boundary conditions (Feyen, 2001). After testing the effect of the boundary condition on the aquifer and the different pumping scenarios, to help address the second question, capture zone analysis of the well fields were conducted. In addition, using different probable models from the stochastic modeling results, capture zone of the five wells within Rochelle was simulated using monthly pumping data obtained from the Rochelle Municipal Utilities (RMU). The pumping datum was for the year 2016, 2017 and 2018 , but the values were averaged and inputted into the model to gain an understanding of the capture zone.

The capture zone was analyzed using MODPATH (Pollock, 2012), which is a particle-tracking post processing program designed to work with MODFLOW (Harbaugh, 2005). Particle tracking codes such as MODPATH (Pollock, 2012) calculates the velocity field from simulated head solutions and use it to track the movement of the particles Boundary conditions, determination of recharge and discharge areas in a modeled aquifer and approximate movement of contaminants can be analyzed using the MODPATH (Pollock, 2012) technique. A particularly common use of particle tracking is to delineate the capture zone of a pumping well (Rayne, 2014). Capture zones within steady-state models can be delineated using particles moving in the forward or reverse direction (Rayne, 2014). To delineate the capture zones, particles were tracked in the backward direction meaning particles were placed in the cell containing the pumping well and all areas within the model domain that the particle can likely move from is delineated as part of the capture zone. The time frame for the backward modeling was set to 54750 days (150 years). Porosity values were inputted into model to help simulate the particle path lines for MODPATH. Porosity values were based on conventional values for shales, carbonates and sands as gleaned from Charley et al., 2015. Maquoketa Shale and Eau Claire had a porosity value of 0.09, St. Peter Sandstone 
and Ironton-Galesville aquifer had a porosity value of 0.45 , Galena Platteville and Franconia Formation had porosity values of 0.15 and 0.4 respectively.

\section{Mass Balance}

Mass balance for cells, zones, and entire model was calculated to understand the total inflows and outflows within the entire model and more importantly individual aquifer layers. Since we run a steady-state model, the inflow should be equal to the outflow and the zones contributing water to individual aquifer layers can be analyzed. Each cell within the calibrated model contains hydraulic conductivity and hydraulic heads information. Using this information, it is possible to determine the rate of flow between two adjacent cells or multiple cells (Seyoum, 2012). Mannix et al., (2018) used a transient, head specified MODFLOW model that determines the mass balance contribution to a region to help conceptualize leakage caused by long open interval wells within the Cambrian-Ordovician aquifers of northeast Illinois. Using the calibrated steady state model, the flow budget for the model on the layer basis and also the pumping wells for Rochelle was calculated using the zone code approach. With the zone code approach, cells within each layer was assigned to a particular number and the amount of water from that particular layer into another layer was computed based on head distribution layer by layer dictating flow. Zone code numbers matches the layer number. For instance, zone code 1 was assigned for layer 1, which in this case is the Maquoketa Shale. In instances where the flow budget for a particular well was needed, a different zone code was assigned to it so as to compute water flowing from the six different zone into that zone for the well. 


\section{Calibration and Sensitivity Analysis}

The calibrated model yielded head values from $243 \mathrm{~m}$ to $140 \mathrm{~m}$ with a southeastern flow regime (Figure 22), where lower heads are located within the eastern section of the model domain and higher heads at the western portion. Model layers had similar flow distribution (Figure 22). DeKalb cone of depression within Ironton-Galesville layer is wider as compared to St. Peter layer.

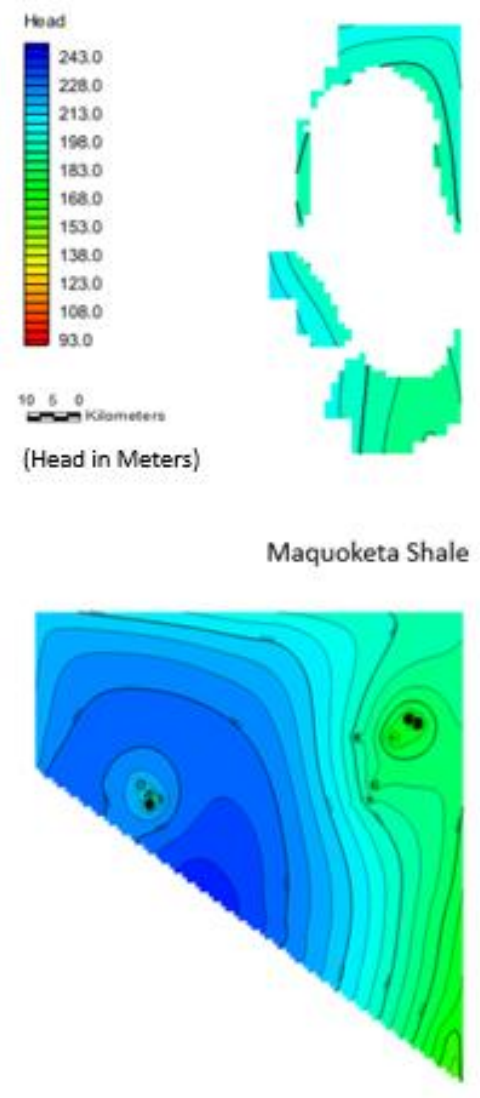

Potosi Franconia

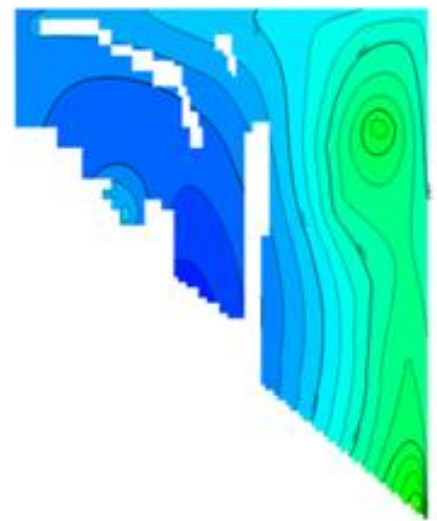

Galena Platteville

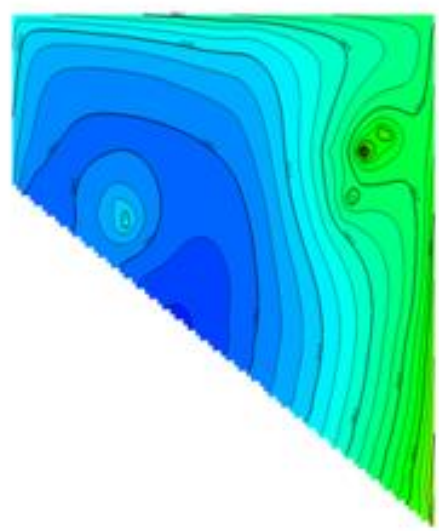

Ironton Galesville
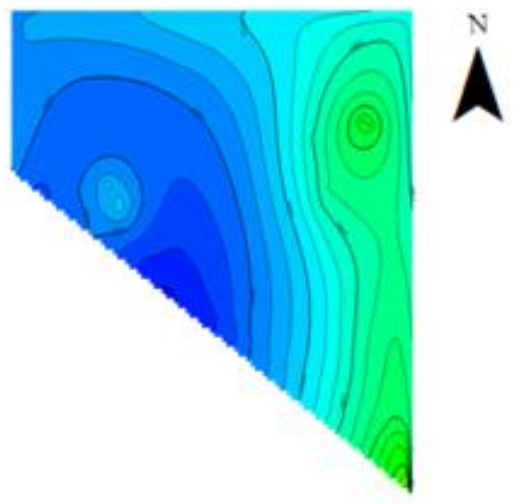

St. Peter Sandstone

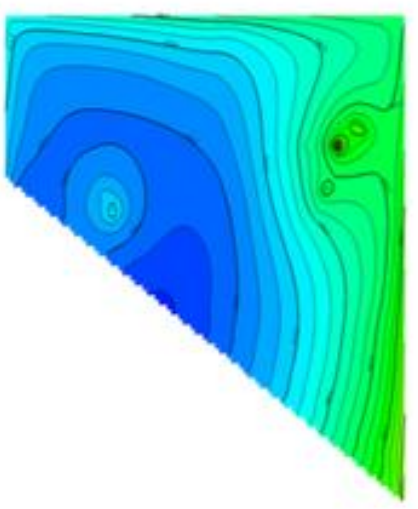

Eau Claire

Figure 22. Map showing the head distribution within all six layers of the calibrated model.

The computed calibrated head for the model matched with the observed or in-situ head for the model. The model had an $\mathrm{R}^{2}$ of 0.991 . Although when it comes to calibration results for a model, there is not necessarily a "goodness of fit" criteria that applies to all cases. The model had a variability of less than 
$1 \%$ for the differences between the simulated and actual conditions. Most of the computed head ( $>90 \%)$ were within the $\pm 2 \mathrm{~m}$ calibration interval set for the model whiles $59 \%$ of the computed heads were within $\pm 1 \mathrm{~m}$ calibration interval (Figure 23 ). Three of the calibration target overpredicted or underpredicted head values exceeding the $\pm 2 \mathrm{~m}$ calibration interval (Figure 23 ). This probably might be as a result of lack of pumping data close to those calibration targets within the model domain which might not be the case in the field.

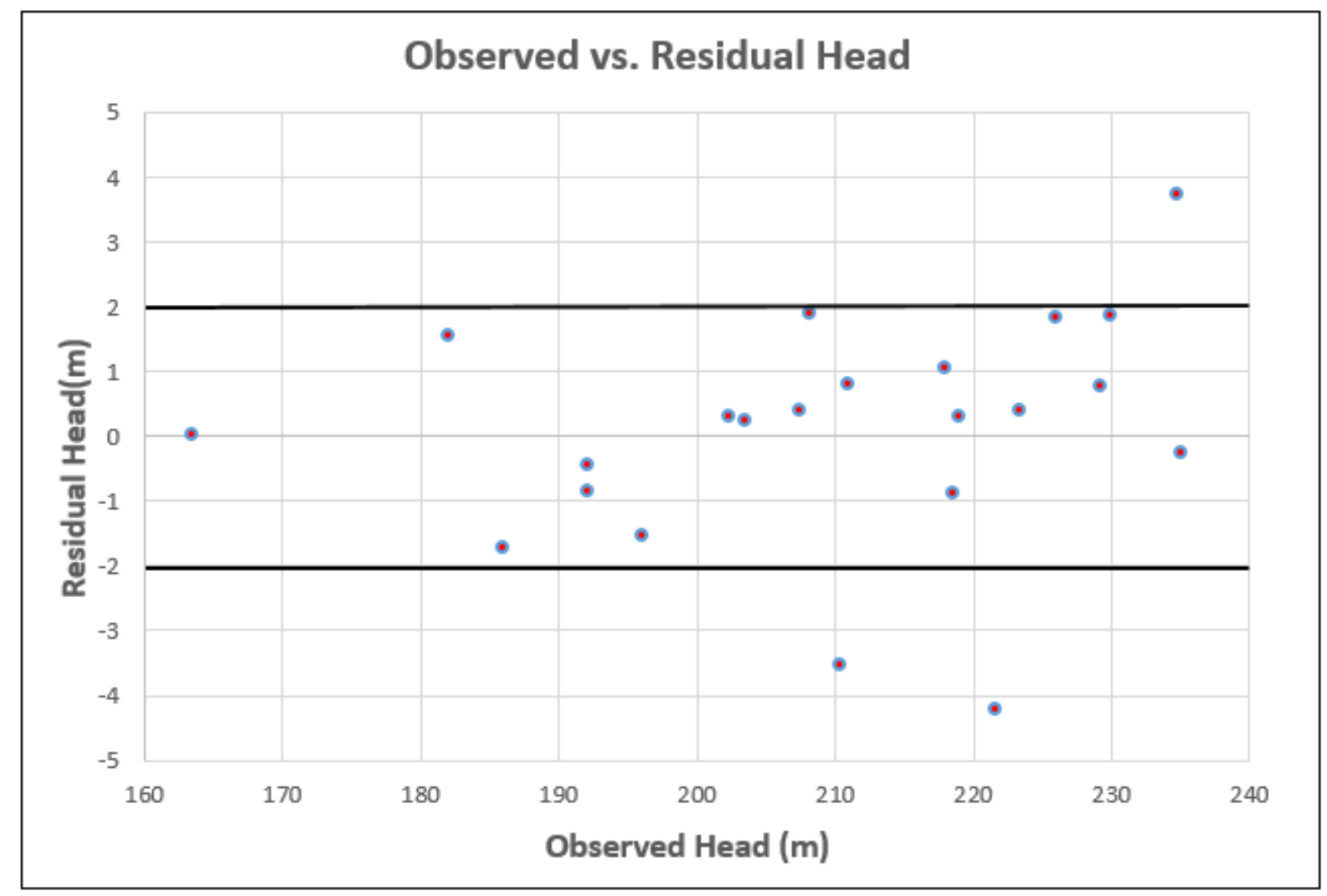

Figure 23. Scatter plot showing observed vs residual heads. Red dots represent the data points and black thick lines represents the $\pm 2 \mathrm{~m}$ calibration interval. Three of the calibration targets fall outside the $\pm 2 \mathrm{~m}$ calibration interval. 
Figure 24 displays the parameters sensitivity in the model. The model was highly sensitive to recharge in zone 5 of Figure 19, horizontal hydraulic conductivity for St. Peters Fault Zone and hydraulic conductivity for Ironton Galesvilles Fault Zone (Figure 24).

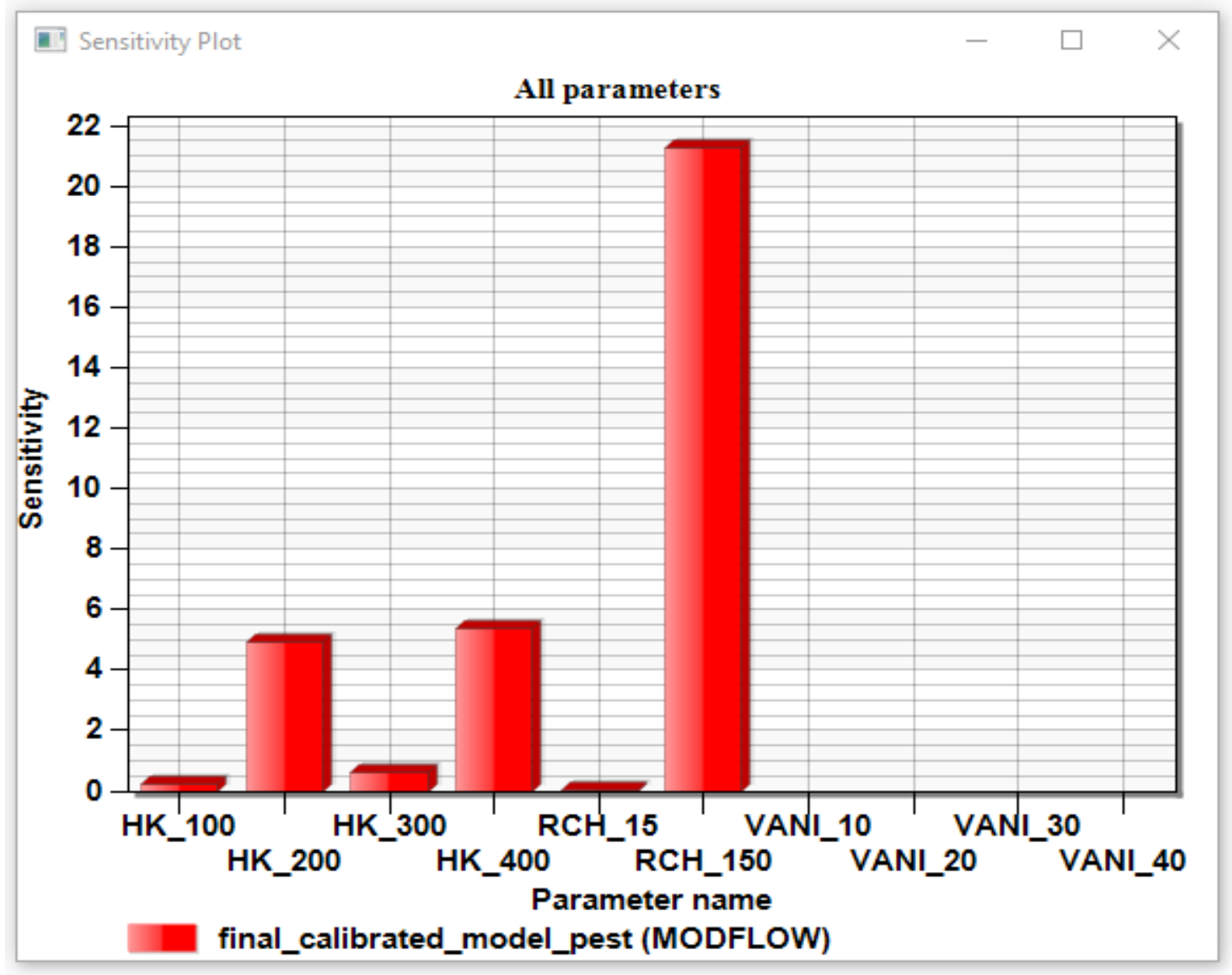

Figure 24. Plot of sensitivity vs parameters. Red bars represents the sensitivity levels for different parameters within the model domain.

To begin the scenario modeling, we needed to know where the current groundwater divide is within our model domain. Figure 25 shows the capture zone delineated from the calibrated model for 1980 based on all pumping wells for the study area. From Figure 25 we can see the capture zones (areas where the blue lines converge) for Rochelle and DeKalb separated by a divide that trends within the center of the model. 


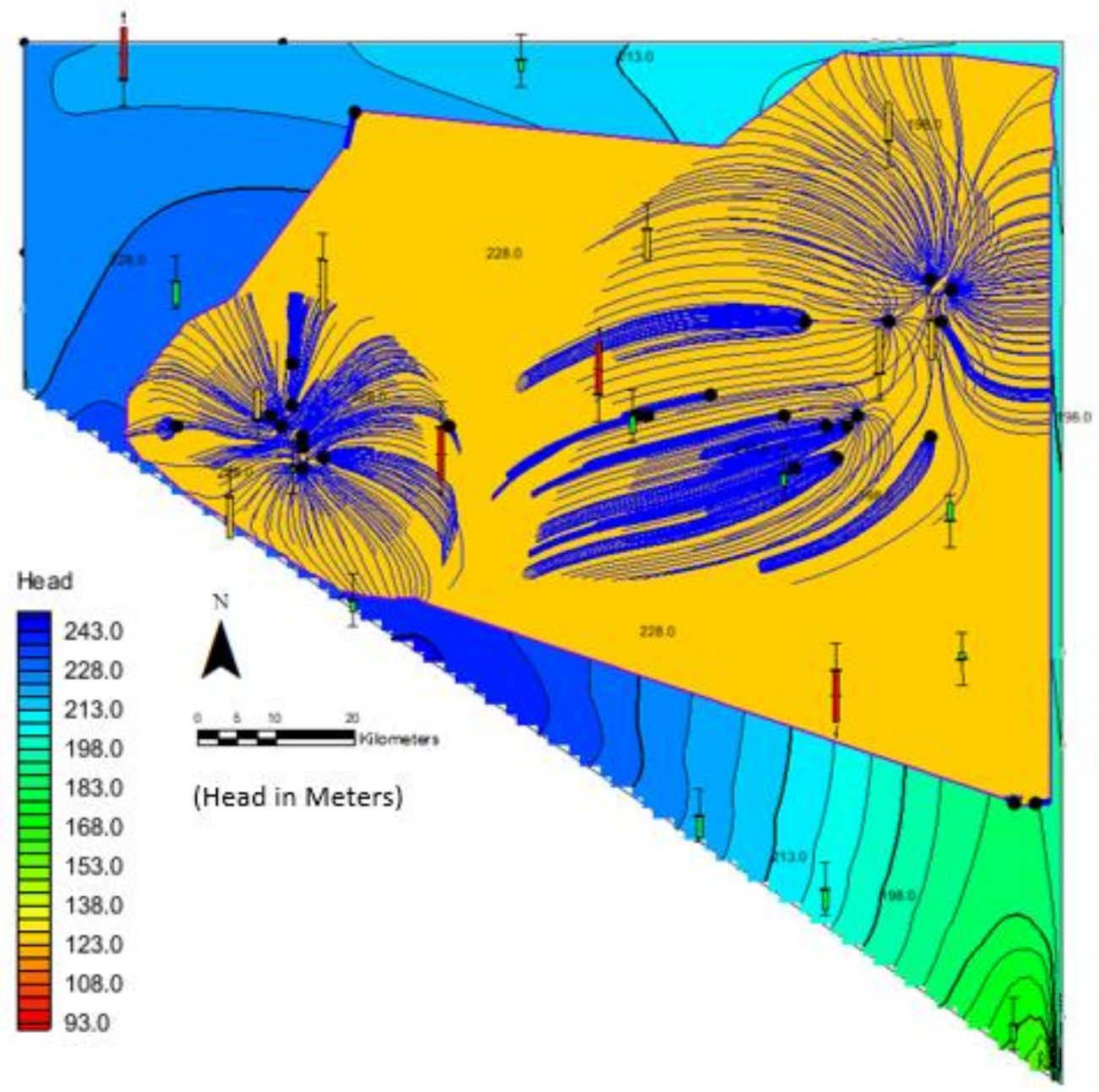

Figure 25. Calibrated Model showing the capture zone for Rochelle on the left side and parts of northeastern Illinois (DeKalb) on the right. The yellow area represents the capture zone for the entire model for the year 1980.

\section{Scenario Model Results}

\section{Scenario 1}

Scenario 1 (Figure 26) represents the first scenario which is lower than the maximum rate for the scenario analysis. Values for scenario 1 (Table 9) represented $48 \%, 39 \%$, and $11 \%$ for Rochelle, DeKalb and southeastern center respectively as compared to the maximum withdrawal rates for the study area (Table 8). Two cones of depressions for Rochelle and DeKalb were evident after running the 
first scenario. The DeKalb cone of depression had lower head as compared to Rochelle's cone of depression. Zone of modeled high $(220 \mathrm{~m})$ represents the groundwater divide is still separating Rochelle and DeKalb.

Table 9. Withdrawal Rate for Different Pumping Centers for Scenario 1.

\begin{tabular}{|c|c|}
\hline Pumping Centers & Total Withdrawals $\left(\mathrm{m}^{3} / d\right)$ \\
\hline Rochelle Area & 5680 \\
\hline DeKalb & 11913 \\
\hline Southeastern Center & 920 \\
\hline
\end{tabular}

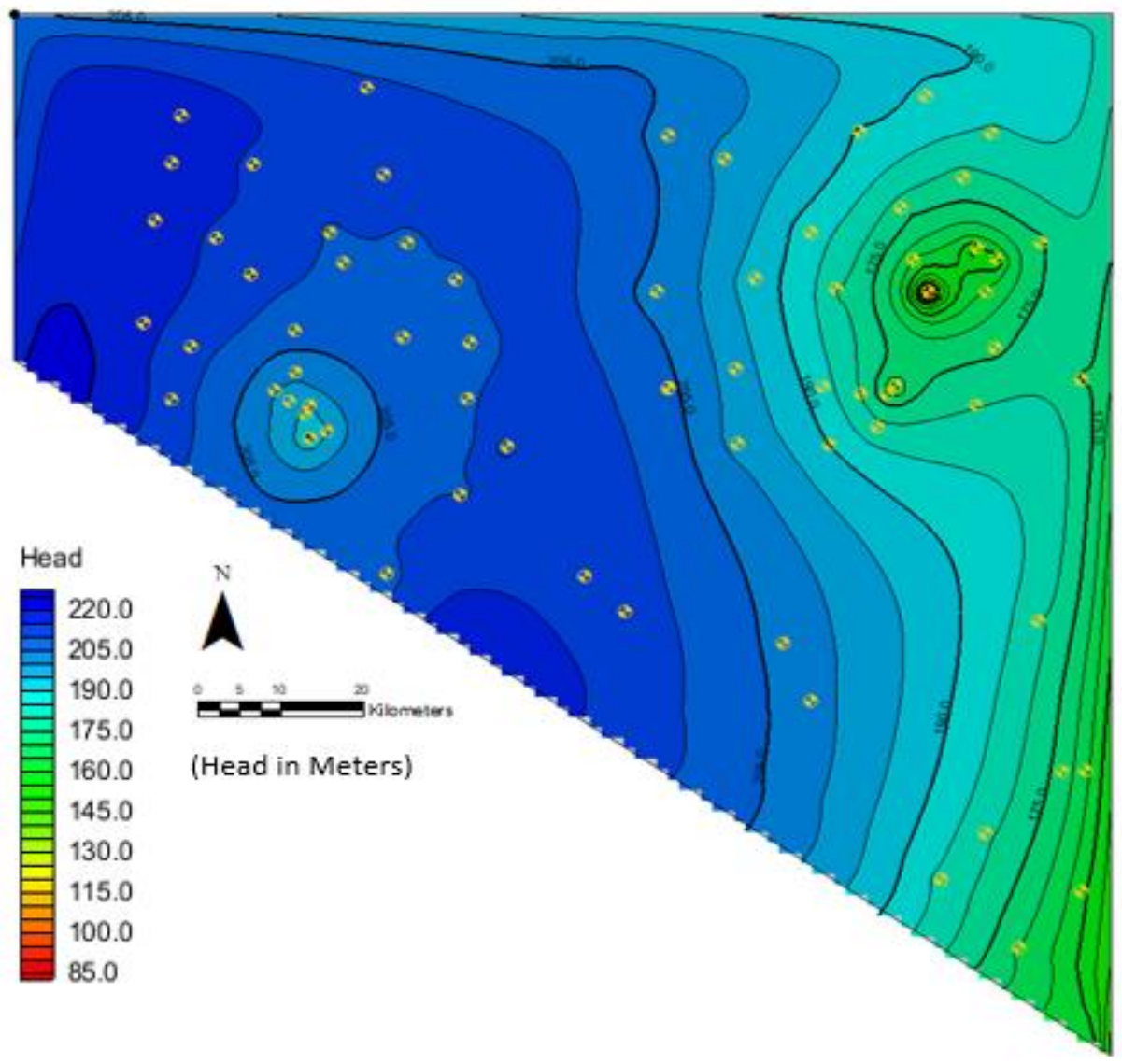

Figure 26. Head distribution for simulated model for Scenario 1 . The color code for head $220 \mathrm{~m}$ which represents zone of modeled high is seen between Rochelle and DeKalb. The dots represents pumping wells used for the scenario process. 


\section{Scenario 2}

Withdrawal values for scenario 2 (Table 10) represents 67\%, 45\%, and $20 \%$ for Rochelle, DeKalb, and southeastern center respectively as compared to maximum withdrawal for the study area (Table 8). Scenario 2 created two cones of depression (Figure 27) for both Rochelle and DeKalb. The groundwater divide from scenario 1 (Figure 26) was still present after running scenario 2, however, with a reduced head from $220 \mathrm{~m}$ to $183 \mathrm{~m}$.

Table 10. Withdrawal Rate for Different Pumping Centers for Scenario 2.

\begin{tabular}{|c|c|}
\hline Pumping Centers & Total Withdrawals $\left(\mathrm{m}^{3} / \mathrm{d}\right)$ \\
\hline Rochelle Area & 7870 \\
\hline DeKalb & 13764 \\
\hline Southeastern Center & 1530 \\
\hline
\end{tabular}




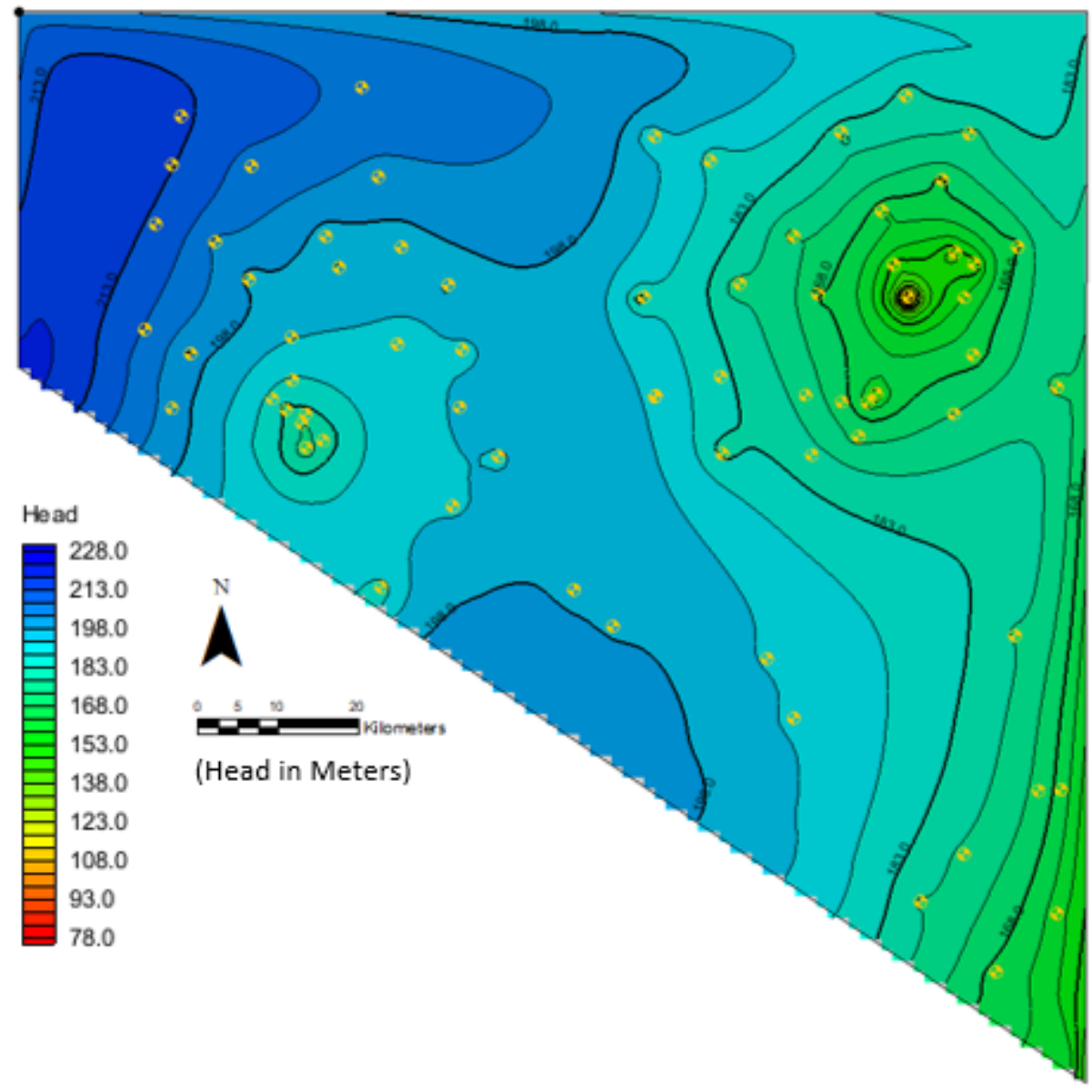

Figure 27. Head distribution for simulated model for Scenario 2. The color code for head $198 \mathrm{~m}$ which represents zone of modeled high is seen between Rochelle and DeKalb. The dots represents pumping wells used for the scenario process.

\section{Scenario 3}

Withdrawal values for scenario 3 (Table 11 ) represents $70 \%, 59 \%$, and $35 \%$ withdrawal value compared to the maximum withdrawal values (Table 8). The two major cones of depression as seen from scenario 1 and 2 expanded after running scenario 3 (Figure 28). The groundwater divide is seen separating Rochelle from DeKalb but with decreased head of $175 \mathrm{~m}$. 
Table 11. Withdrawal Rate for Different Pumping Centers for Scenario 3.

\begin{tabular}{|c|c|}
\hline Pumping Centers & Total Withdrawals $\left(\mathrm{m}^{3} / \mathrm{d}\right)$ \\
\hline Rochelle Area & 8200 \\
\hline DeKalb & 17863 \\
\hline Southeastern Centre & 2700 \\
\hline
\end{tabular}

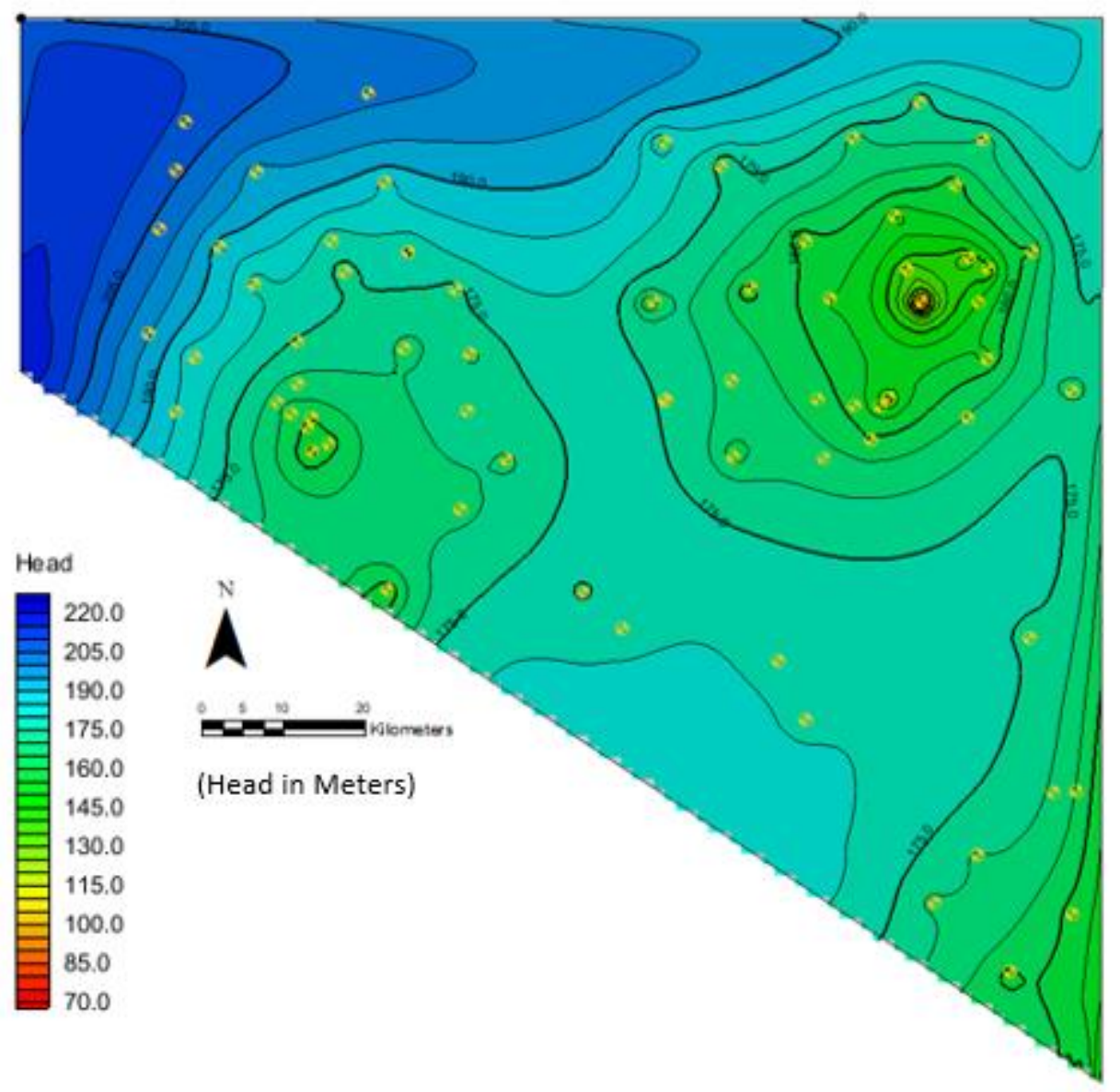

Figure 28. Head distribution for simulated model for Scenario 3. The color code for head $160 \mathrm{~m}$ which represents zone of modeled high is seen between Rochelle and DeKalb. The dots represents pumping wells used for the scenario process. 


\section{Scenario 4}

Withdrawal values (Table 12) for scenario 4 represents $93 \%, 99 \%$, and $55 \%$ of the maximum withdrawal amount (Table 8) for the study area. The two cones of depression from earlier scenarios were still present but are wider in size (Figure 29). Groundwater divide still present within the model domain with decreased head of $165 \mathrm{~m}$.

Table 12. Withdrawal Rate for Different Pumping Centers for Scenario 4.

\begin{tabular}{|c|c|}
\hline Pumping Centers & Total Withdrawals $\left(\mathrm{m}^{3} / d\right)$ \\
\hline Rochelle Area & 10694 \\
\hline DeKalb & 29863 \\
\hline Southeastern Centre & 4200 \\
\hline
\end{tabular}

The withdrawal amount matches closely with the total withdrawal amount for the area obtained

from Abrams et al., 2018. This amount was taken as the final scenario so as not to exceed the amount in Table 8. 


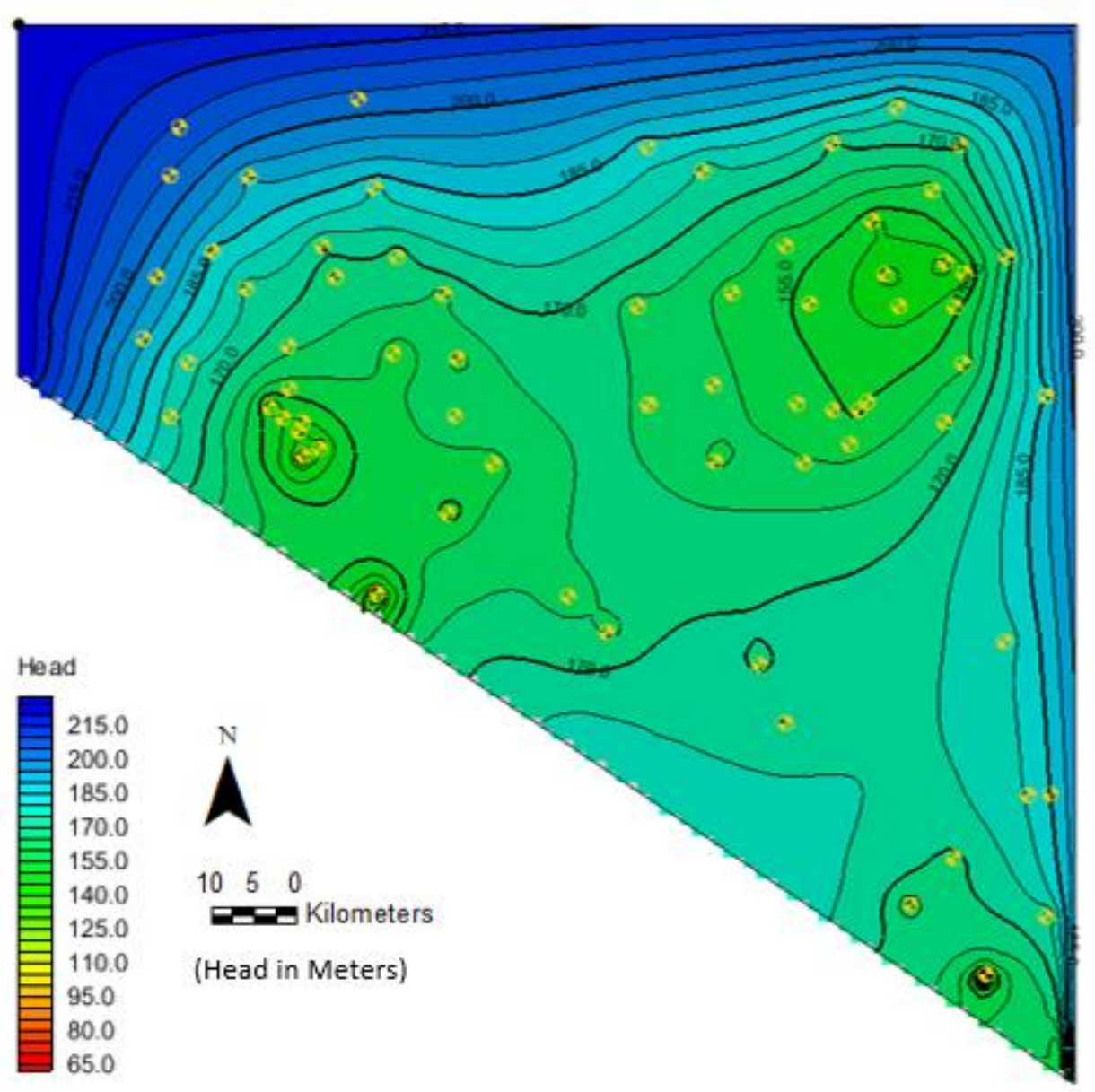

Figure 29. Head distribution for simulated model for Scenario 4. The color code for head $165 \mathrm{~m}$ which represents zone of modeled high is seen between Rochelle and DeKalb. The dots represents pumping wells used for the scenario process.

\section{Capture Zone Results}

The contributory areas to the Rochelle's wellfield were simulated using the stochastic modeling approach to generate the capture zone. Fifty probable models were generated with the capture zones simulated. Path lines for the capture zone of all four models were mostly from lateral flow within the Ironton-Galesville aquifer. However, some of the path lines originated from the overlying Franconia Formation (Figure 30, 31, 32 and 33). The highest travel time for the four models was 54750 days (150 
years) and the least being 29200 days (80 years) (Table 13). The average backward time to start seeing leakage from the overlying Franconia Formation to the Ironton-Galesville aquifer is 121 years.

Table 13: Parameter Differences for Stochastic Models and Travel Times for Capture Zones.

\begin{tabular}{|c|c|c|c|c|c|c|c|}
\hline \multirow{3}{*}{ Model } & \multicolumn{7}{|c|}{ Parameters } \\
\hline & \multicolumn{2}{|c|}{$\begin{array}{c}\text { St. Peter } \\
\text { (Horizontal K) } \\
\text { (m/d) }\end{array}$} & \multicolumn{2}{|c|}{$\begin{array}{l}\text { Ironton-Galesville } \\
\text { (Horizontal K) (m/d) }\end{array}$} & \multicolumn{2}{|c|}{ Recharge $(\mathrm{m} / \mathrm{d})$} & \multirow[t]{2}{*}{$\begin{array}{l}\text { Travel } \\
\text { times } \\
\text { (days) }\end{array}$} \\
\hline & Zone 1 & Zone 2 & Zone 1 & Zone 2 & Zone 4 & Zone 5 & \\
\hline$A$ & 3.2762 & 0.33867 & 3.0770 & 0.20803 & $0.50708 \times 10^{-4}$ & $0.19062 \times 10^{-5}$ & 54750 \\
\hline$B$ & 2.2238 & 2.2164 & 0.45804 & 0.89742 & $0.12607 \times 10^{-3}$ & $0.99107 \times 10^{-6}$ & 49275 \\
\hline $\mathrm{C}$ & 2.0776 & 0.18680 & 2.5102 & 2.8407 & $0.72973 \times 10^{-4}$ & $0.26514 \times 10^{-5}$ & 43800 \\
\hline $\bar{D}$ & 4.6551 & 0.16636 & 0.52354 & 1.7080 & $0.23184 \times 10^{-3}$ & $0.29578 \times 10^{-5}$ & 29200 \\
\hline
\end{tabular}


Model A

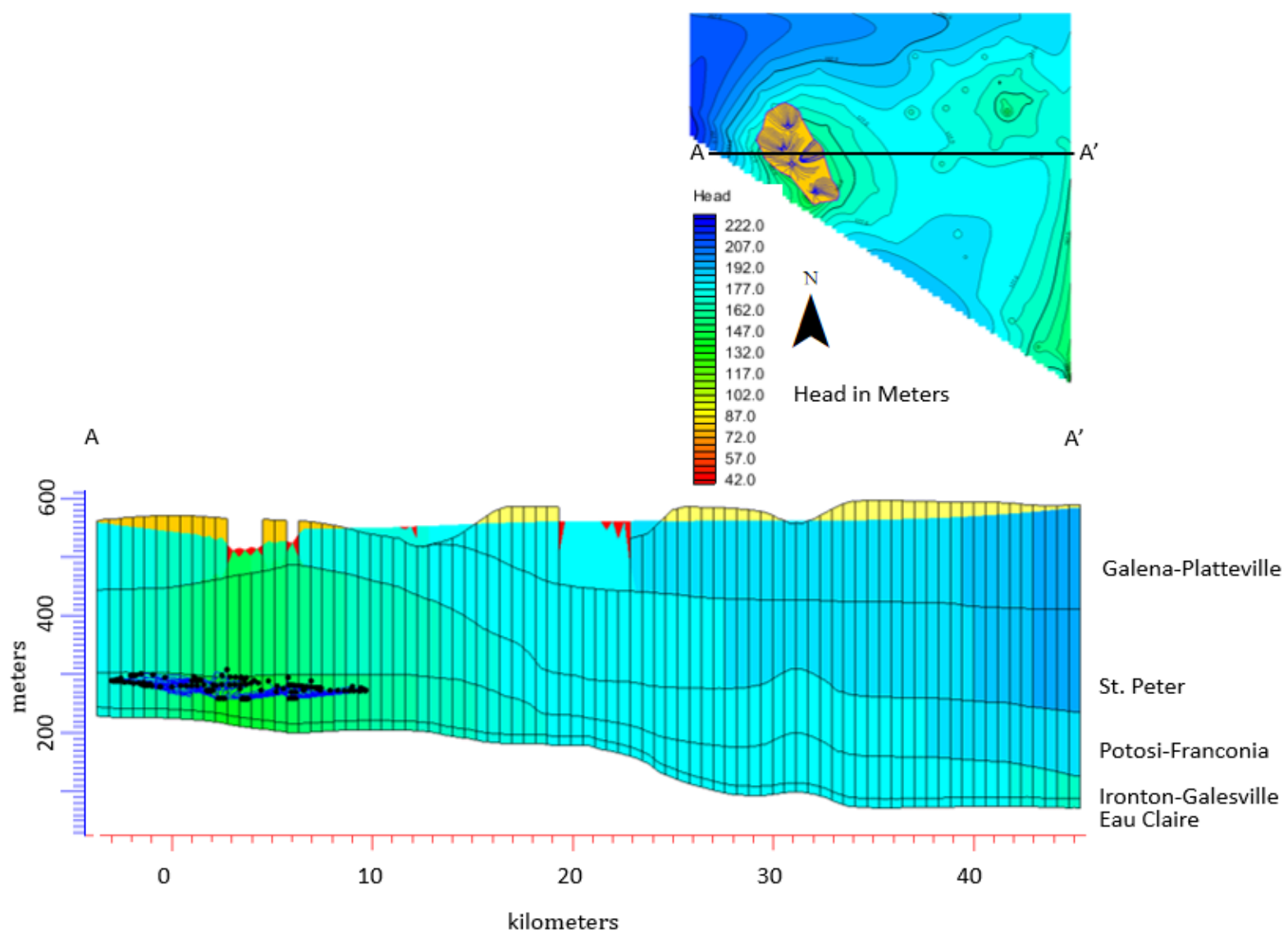

Figure 30. A-A' cross section of Model A. Blue lines represents path lines for the capture zone. Black dot represents the starting location of the path lines. Some of the black dots originates from the overlying Franconia Formation. 
Model B

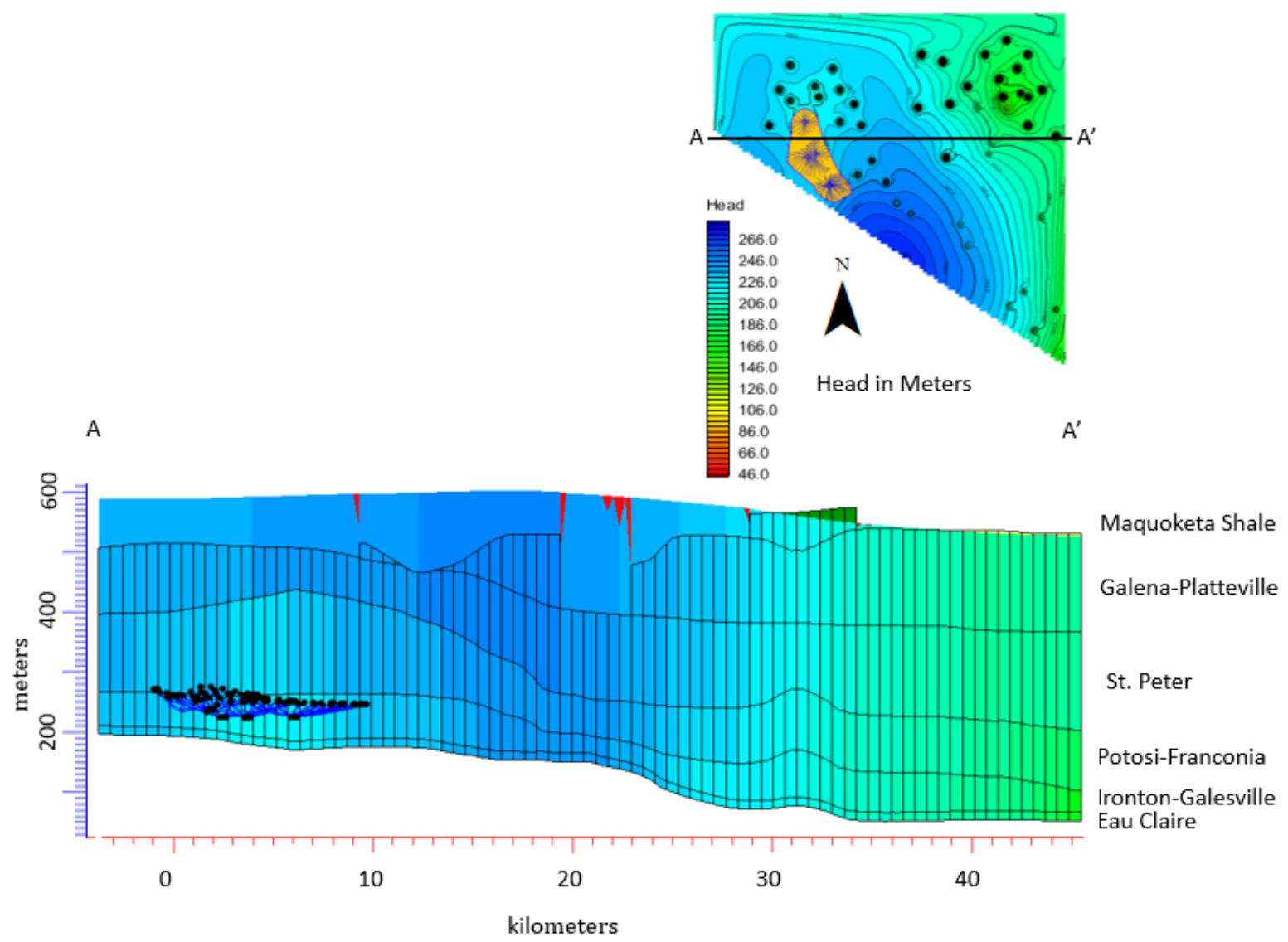

Figure 31. A-A' cross section of Model B. Blue lines represents path lines for the capture zone. Black dot represents the starting location of the path lines. Some of the black dots originates from the overlying Franconia Formation. 
Model C

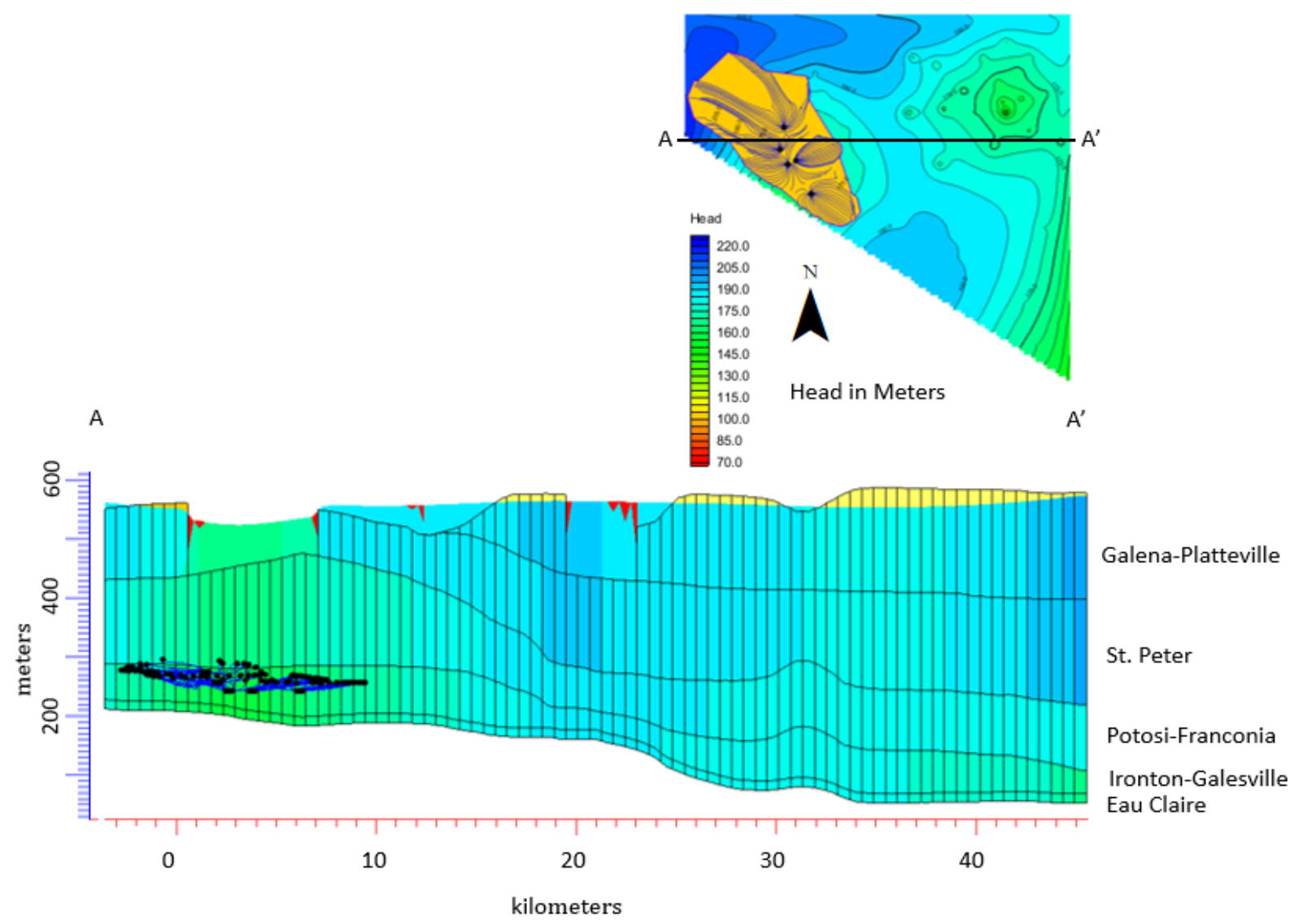

Figure 32. A-A' cross section of Model C. Blue lines represents path lines for the capture zone. Black dot represents the starting location of the path lines. Some of the black dots originates from the overlying Franconia Formation. 
Model D

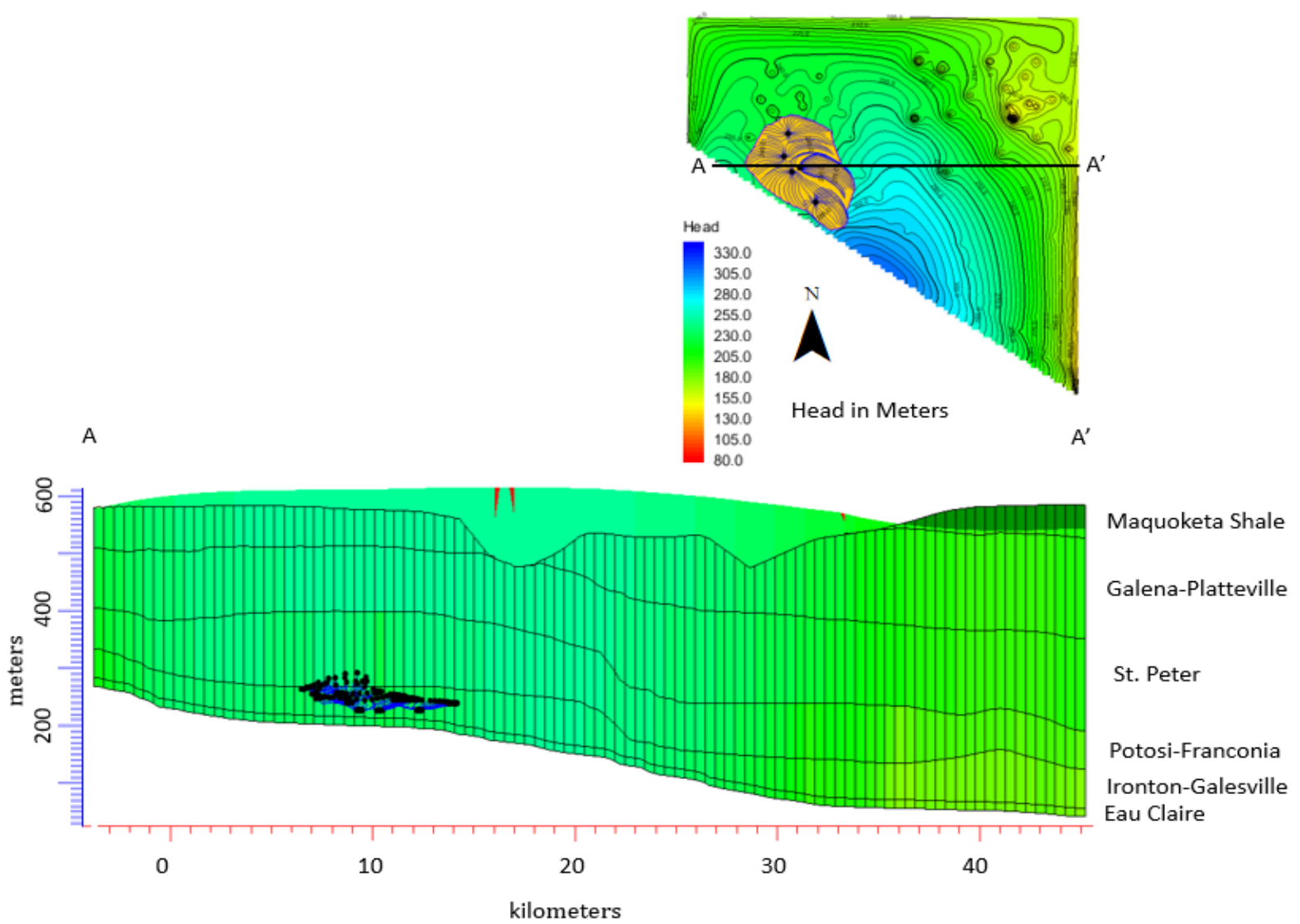

Figure 33. A-A' cross section of Model D. Blue lines represents path lines for the capture zone. Black dot represents the starting location of the path lines. Some of the black dots originates from the overlying Franconia Formation.

\section{Mass Balance Results}

The components of the water budgets includes recharge to the highest active cells, flow from or into the boundaries, and pumping. The percent discrepancy for the entire model was $0.00003462 \%$. Percent discrepnacy is calculated by the subtracting the output for the model from the input and dividing by the input and multiplied by $100 \%$. The percent discrepancy is a good measure of the validity of the model, perccent discrepancy of less than $5 \%$ is commonly acceptable for steady-state model. From the total inflows to the entire model, $85 \%$ comes from the constant head boundary and the remaining $15 \%$ comes 
from recharge from precipitation. From the outflows, $72 \%$ leaves the model domain via the constant head boundary whiles the remaining $28 \%$ outflow is removed by the pumping wells (Table 14 ).

Table 14. Mass Balance for the Entire Model.

\begin{tabular}{|l|l|l|l|l|}
\hline Mass Balance Components & $\ln \left(\mathrm{m}^{3} / \mathrm{d}\right)$ & Out $\left(\mathrm{m}^{3} / \mathrm{d}\right)$ & $\ln (\%)$ & Out(\%) \\
\hline Constant head(Boundary) & 24159.58 & 208946.90 & 85.75 & $71.9 \%$ \\
\hline Recharge & 41391.50 & 0.0 & 14.3 & 0.0 \\
\hline Wells & 0.0 & 81604.08 & 0.0 & $28.1 \%$ \\
\hline Total & 290551.08 & 290550.9 & 100 & 100 \\
\hline IN-OUT & 0.10061 & & & \\
\cline { 1 - 2 } & & & &
\end{tabular}

The mass balance for the aquifer layers were determined from the hydraulic data gained from the model simulation through the different zones. Components for the mass balance for the layers comes from recharge from precipiation, constant head (boundary), wells and other contributory layers to that aquifer layer (Figure 34). Mass balance for the major aquifers that is the St. Peter and Ironton-Galesville aquifer together with the Potosi Franconia is provided Table 15,16 and 17. 
Table 15. Mass Balance for St. Peter.

\begin{tabular}{|c|c|c|c|c|c|c|}
\hline In- Flows & $\mathrm{m}^{3} / \mathrm{d}$ & $\%$ & & Out-flows & $\mathrm{m}^{3} / \mathrm{d}$ & $\%$ \\
\hline Constant Head & 248337.78 & 85.0 & & Constant Head & 182.61 & 0.06 \\
\hline Recharge & 8538.75 & 2.9 & & Well & 22348.46 & 7.65 \\
\hline Zone 2 to Zone 3 & 34967.89 & 11.9 & & Zone 3 to Zone 2 & 2123.53 & 0.74 \\
\hline Zone 4 to Zone 3 & 29.8199 & 0.1 & & Zone 3 to Zone 4 & 267227.9 & 91.55 \\
\hline Total & 291874.25 & 100 & & Total & 291882.599 & 100 \\
\hline In - Out & 291874.25 & & - & 291882.59 & -0.09037 & \\
\hline Percent Discrepancy & -0.00003096 & & & & & \\
\hline
\end{tabular}

Table 16. Mass Balance for Franconia.

\begin{tabular}{|c|c|c|c|c|c|c|}
\hline In- Flows & $\mathrm{m}^{3} / \mathrm{d}$ & $\%$ & & Out-flows & $\mathrm{m}^{3} / \mathrm{d}$ & $\%$ \\
\hline Constant Head & 0 & 0 & & Constant Head & 0 & 0 \\
\hline Recharge & 0 & 0 & & Well & 22731.18 & 8.28 \\
\hline Zone 3 to Zone 4 & 267227.9 & 97.6 & & Zone 4 to Zone 3 & 29.81 & 0.01 \\
\hline Zone 5 to Zone 4 & 7036.23 & 2.4 & & Zone 4 to Zone 5 & 251503.1 & 91.7 \\
\hline Total & 274264.22 & 100 & & Total & 274264.20 & 100 \\
\hline In - Out & 274264.2 & & - & 274264.20 & 0.0255 & \\
\hline Percent Discrepancy & -0.0000093 & & & & & \\
\hline
\end{tabular}


Table 17. Mass Balance for Ironton-Galesville.

\begin{tabular}{|c|c|c|c|c|c|c|}
\hline In- Flows & $\mathrm{m}^{3} / \mathrm{d}$ & $\%$ & & Out-flows & $\mathrm{m}^{3} / \mathrm{d}$ & $\%$ \\
\hline Constant Head & 821.79 & 0.3 & & Constant Head & 208764.29 & 82.74 \\
\hline Recharge & 0 & 0 & & Well & 36524.43 & 14.47 \\
\hline Zone 4 to Zone 5 & 251503.19 & 99.6 & & Zone 5 to Zone 4 & 7036.23 & 2.78 \\
\hline Zone 6 to Zone 5 & 0.11083 & 0.000043 & & Zone 5 to Zone 6 & 0.1108 & 0.00004 \\
\hline Total & 252325.10 & 100 & & Total & 252325.06 & 100 \\
\hline In - Out & 252325.10 & & - & 252325.06 & 0.031038 & \\
\hline Percent Discrepancy & 0.0000123 & & & & & \\
\hline
\end{tabular}

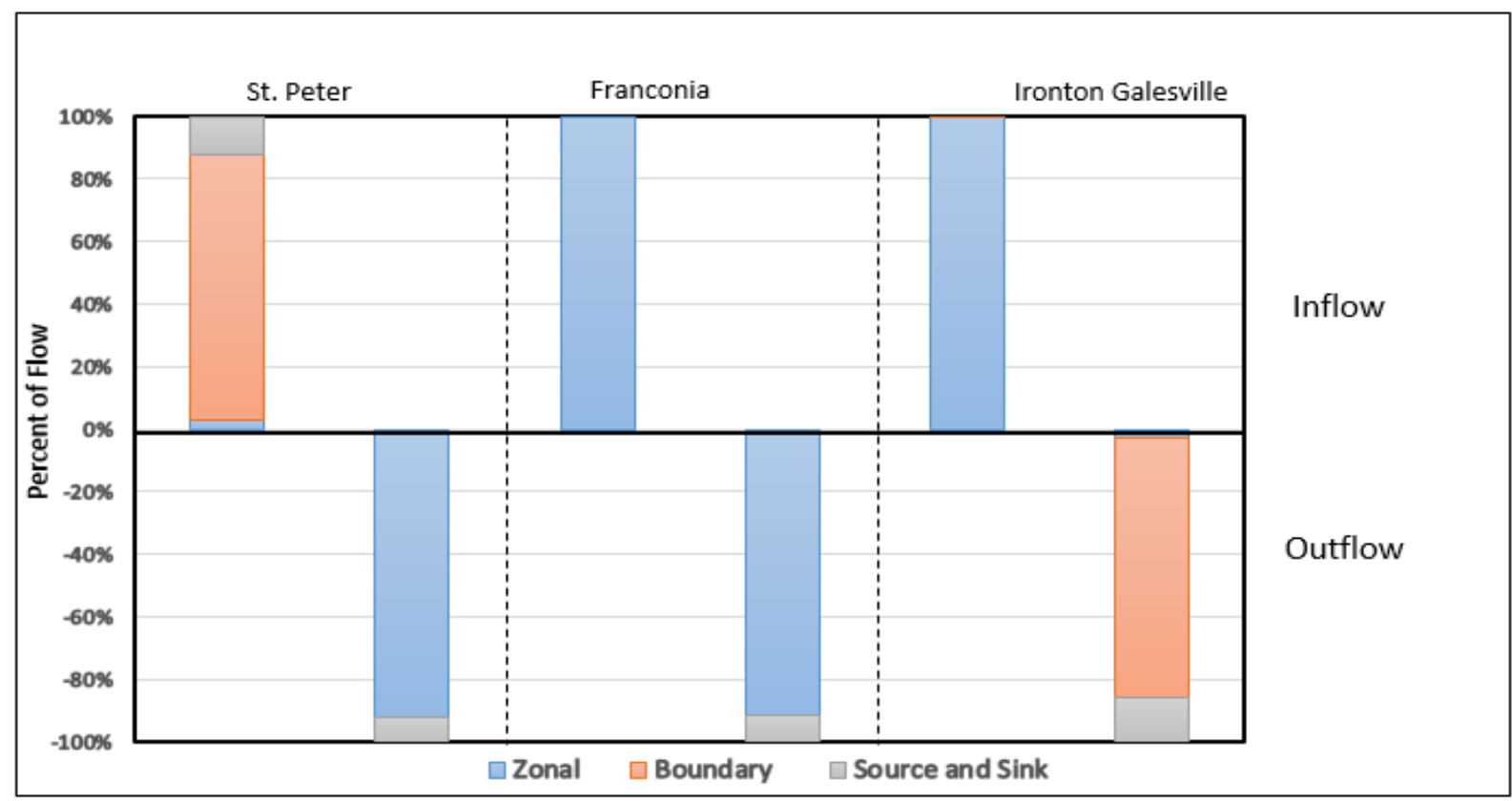

Figure 34. Percentage stacked bar chart showing the mass balance within the St. Peter, Franconia and Ironton-Galesville. 


\section{Mass Balance for Well 12}

Mass balance for well 12 was analysed by alternating the pumping rate for well 12 and analysing the amount of water withdrawn by the well and determining which layers are contributing water. Specifically, leakage from the overlying unit, which is the Franconia Unit, was mainly considered. Table 18 shows the different pumping rates applied and the corresponding leakage from the Franconia Unit. As shown in the Table 18, as pumping increases, the leakage from Franconia increases.. There is a positive relationship between pumping and rate of leakage from Franconia formation to Ironton-

Galesville aquifer

Table 18. Pumping Rate vrs Leakage from Franconia to Ironton Galesville for Well 12.

\begin{tabular}{|c|c|}
\hline Pumping Rate $\left(\mathrm{m}^{3} / \mathrm{d}\right)$ & From Zone 4 to Zone \\
& 5(Leakage Rate $\left.\left(\mathrm{m}^{3} / \mathrm{d}\right)\right)$ \\
\hline 10 & 64 \\
\hline 100 & 68 \\
\hline 200 & 72 \\
\hline 300 & 76 \\
\hline 400 & 80 \\
\hline 500 & 84 \\
\hline 600 & 88 \\
\hline 700 & 92 \\
\hline 800 & 95.8 \\
\hline 900 & 100 \\
\hline 1000 & 103 \\
\hline 1200 & 111 \\
\hline 1500 & 123.6 \\
\hline 2000 & 142.6 \\
\hline 4000 & 228 \\
\hline
\end{tabular}




\section{CHAPTER IV: DISCUSSION AND INTERPRETATION}

\section{Groundwater Flow and Model Sensitivity}

The high $\mathrm{R}^{2}$ value of 0.991 and low RMSE OF $1.74 \mathrm{~m}$ for the model is deemed acceptable according to similar publication involving groundwater flow models (Yidana et al., 2013: Seyoum and Eckstein, 2014; Mannix et al., 2018). The calibrated model suggested a general southeastern (SE) trend in groundwater flow (Figure 22), which is in tune with the general flow for the Lake Michigan basin (Abrams et al., 2015; Visocky et al., 1985). Although we have localized flow paths, the regional flow path moves to the Lake Michigan, which serves as a regional sink. Similar modeling work done by Abrams et al., (2015) also showed a SE groundwater flow pattern for the Cambrian-Ordovician aquifer system in the study area. The head contours for the layers looks similar, which might be as a result of long open interval wells that are prevalent in northern Illinois (Figure 22). Well data used for the model were opened to different aquifer layers especially the St. Peter and Ironton- Galesville Sandstone. Long open interval wells allow cross connectedness of different aquifers layers that allows the head distributions for multiple aquifers to equilibrate over time. Mannix et al. (2018) found out artificial leakage by long open interval wells within northeastern Illinois contributed to a minimum of $10-13 \%$ of total flow to the deep Cambrian-Ordovician sandstone aquifers. Also, the general SE flow path (Figure 22) is exacerbated by pumping centers within the eastern section of the model domain; hence, lower head distribution for the eastern section of the model. The stratigraphy of the area dips southeast to Lake Michigan (Abrams et al., 2015) so it makes sense if we have our flow moving in that direction. Groundwater flow within the model domain is influenced by the layering and dips of the stratigraphic units, Lake Michigan which serves as a regional sink as well as pumping centers within the northeastern portion of Illinois.

The model was sensitive to recharge and horizontal hydraulic conductivity for St. Peter Fault Zone and Ironton-Galesville Fault Zone. The very high sensitivity of the model to recharge might be due to the presence of St Peter aquifer close to the ground surface within those recharge zones. Hence, any change 
in recharge value for that zone will have an effect on the head distribution with the St. Peter and probably the Ironton-Galesville aquifer. For this reason, zones of recharge were created and subsequently calibrated so as to minimize errors that will arise from recharge value within the model.

\section{Shift in Groundwater Divide}

Previous research (Abrams et al. 2015; Visocky et al., 1985) indicated that there exists a groundwater divide close to Rochelle that seperates the catchment area from northeastern Illinois (Figure 25). This is possible because of the presence of the deep bedrock aquifers close to the ground surface (e.g. St. Peter crops out close to the divide) and the confining layer is missing in this part of the area. This allows direct recharge to the deep bedrock aquifers and forms a groundwater mound in this part of the area (Abrams et al., 2015). The presence of the Maquoketa Shale in the remaining part of the study area prevents recharge to deep aquifers. Different pumping scenarios although had an effect on the groundwater divide, the cone of depressions within the DeKalb area and Rochelle didn't converge completely. This can be seen in Figure 35, within the red inset, the velocity vectors for the flowpaths for the maximum pumping scenario shows groundwater flow moving away in opposite directions. If the divide was non-existent, the velocity vectors will cut across where the groundwater divide currently is. However, the velocity vector arrows are not crossing each other based on the presence of the groundater divide after withdrawal rates have been applied. The total convergence of the two cones of depression would be an indication of possible transport of already contaminated Ra waters traveling to Rochelle's wellfield. This was further backed by the stochastic models created from the calibrated model. The capture zones for Rochelle's wellfield was still concentrated just within the Rochelle area and did not cross over to the DeKalb area. Also, the stochastic models still simulated the groundwater divide, which tells us that although the model parameters can be varied, the groundwater divide still occurs seperating the flowpaths between the two capture zones, Rochelle and DeKalb. 


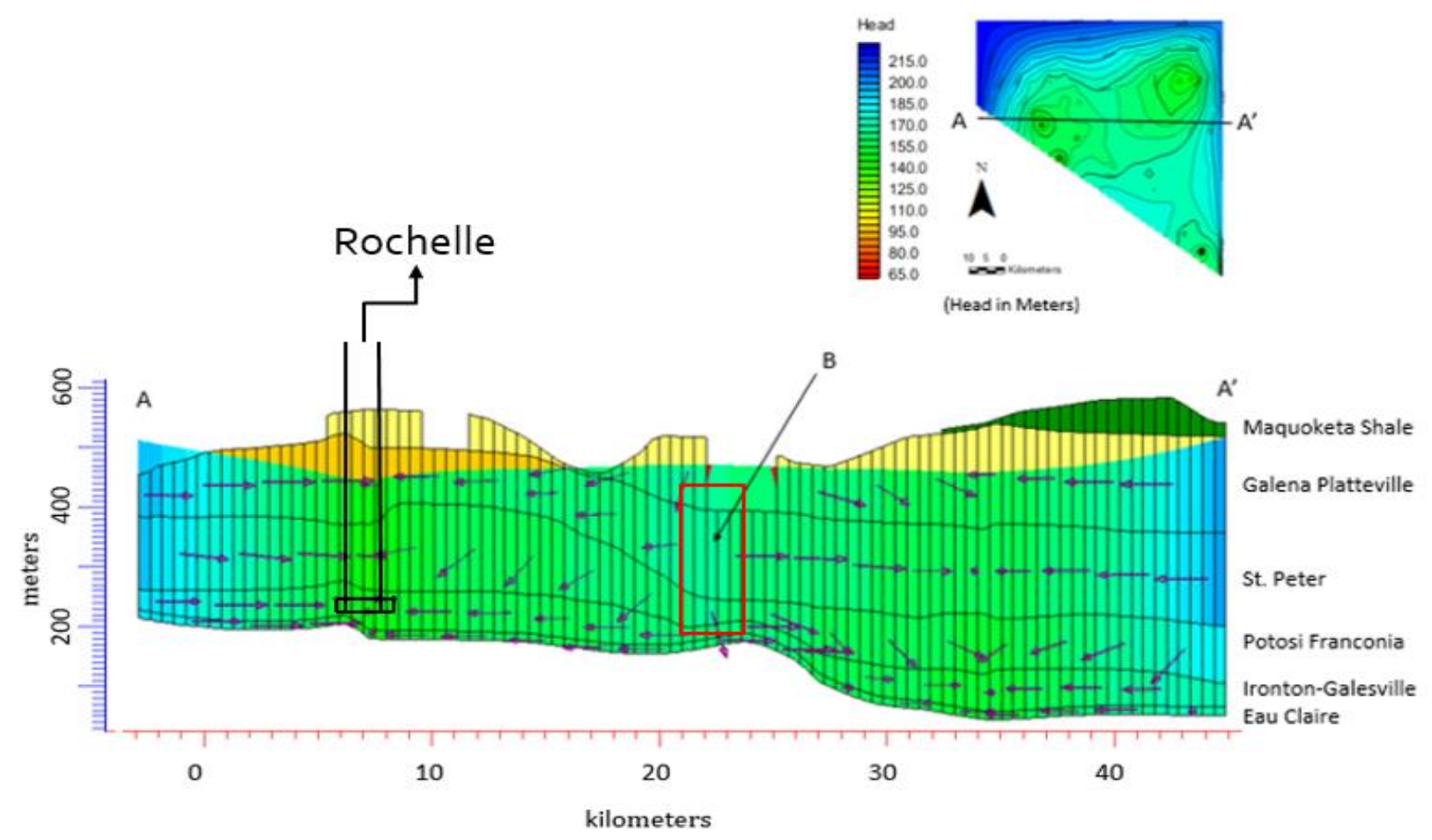

Figure 35. A-A' cross section showing the flow velocity vectors for Scenario 4 moving away from the groundwater divide. Scenario 4 was choosen based on the fact that it is the highest withdrawal rate that could be tested based on the withdrawal map modified from Abrams et al., (2018). The red inset represents the location of the groundwater divide

\section{Capture Zone and Mass Balance}

Results from the capture zones and mass balance shows leakage occurring within the study area from the Franconia Formation to the Ironton-Galesville Sandstone. The capture zones show that it takes average of 121 years for a water molecule to move from the Franconia Formation into the wells when back tracked. The town of Rochelle has been depending on groundwater for so many years likewise most towns within northern Illinois where deep bedrock aquifers serves as the main source of water (Visocky et al., 1985). To verify the leakage happening, we altered the pumping rate to see whether the amount of leakage increases. From Table 18, there is a positive relationship between pumping rate and leakage rate. As we increase pumping, the amount of leakage from the overlying Franconia Formation to the Ironton-Galesville aquifer increases. This goes on to answer our second research question where we 
can see an interaction between the overlying Franconia Formation into the Ironton Galesville aquifer. Velocity vectors from Scenario 4 also shows velocity vectors from the Franconia Formation directed towards Rochelle's wellfield (Figure 36).

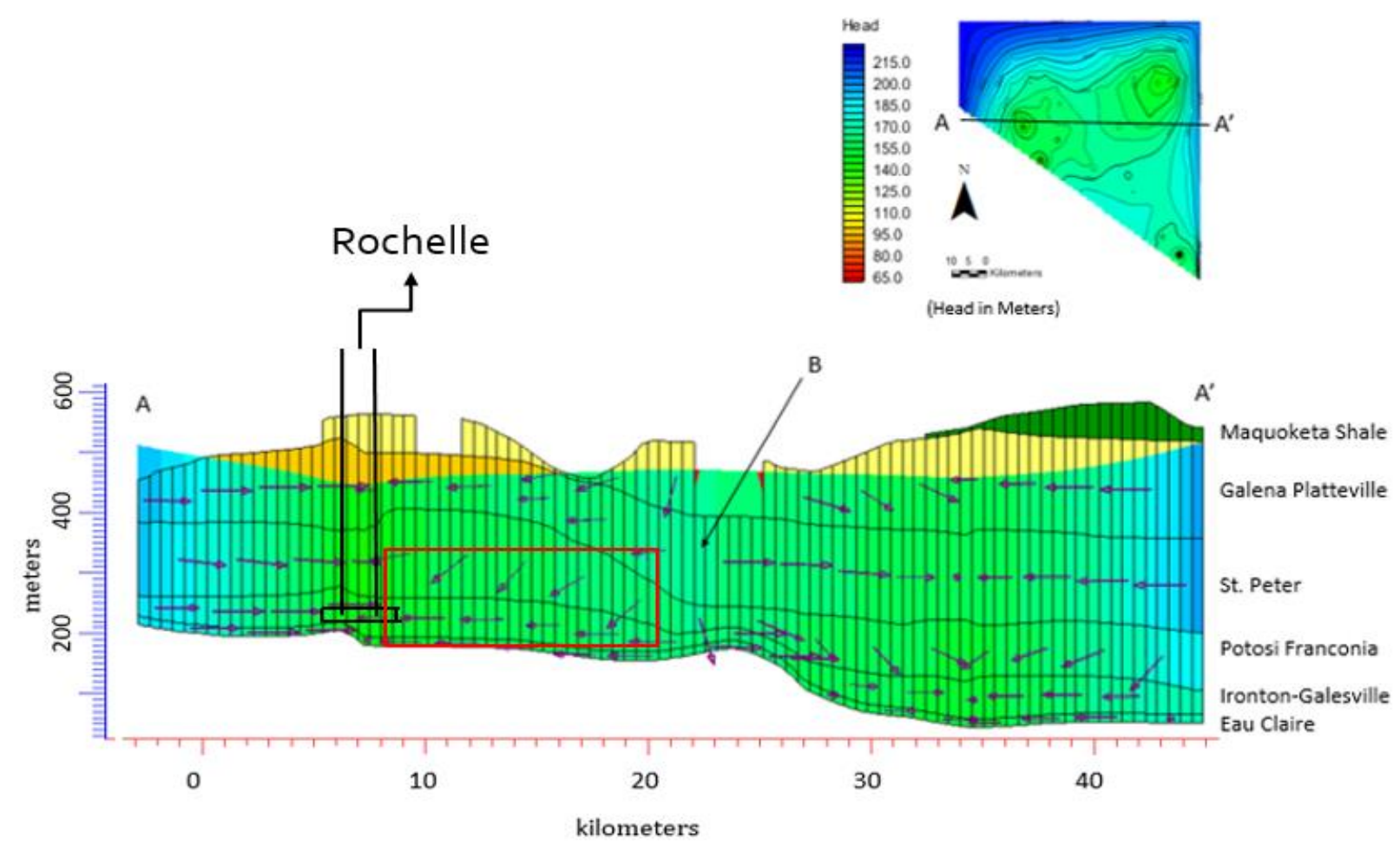

Figure 36. Cross section A-A' showing the flow velocity vectors for scenario 4 directed from the Franconia towards Ironton-Galesville. Scenario 4 was choosen based on the fact that it is the highest withdrawal rate that could be tested based on the withdrawal map modified from Abrams et al., (2018).

The red inset represents the location of the velocity vectors from the Franconia Formation directed towards Ironton-Galesville.

\section{Model Gaps and Recommendation}

The model created for this study lumped both the Potosi and Franconia formation as one hydrostratigraphic unit and was denoted a dolomitic unit based on other modeling work such as Abrams et al. (2015). This was done to reduce model complexity and run time by reducing the number of hydrostratigraphic units in the model and both Potosi and Franconia generally have similar hydrogeologic 
properties. However, a different model where those units are seperated and the Franconia is seperately treated as more of a sandstone unit than a dolomitic unit will be ideal.

A steady-state model was used to help address the objective of this study. However, a transient model which is best suited to simulate various scenarios of stresses on aquifer is more ideal. Specifically, transient model is ideal to determine the shift in the groundwater divide. A steady-state model was built mainly due to the absence of transient data to calibrate a transient model. With a transient model, a variable pumping rate can be applied to a well and changes in storage due to pumping overtime can be viewed, which is the case in the field. However, the steady state model built for this study assessed the research objectives by running multiple steady state model with different pumping rate.

Another major gap in the model was the absence of the glacial sediment. This was largely due the absence of regional simulated head for the area from which specified head conditions could be gleaned from and used for a local model like ours. Also, whenever the model was simulated with the glacial surface, the potentiometric head fell below the glacial layer resulting in non convergence of the model. If only specified head conditions for the glacial can be obtained, a model containing the glacial surface will be appropriate.

Furthermore, the model in this study considered the Sandwich Fault as a physical barrier feature to be used as a no flow boundary condition for the model. However, a similar model that does not treat the Sandwich Fault as a boundary but rather a component witihn the model domain will be better to aid in visualizing the flow paths southward from the fault where the Franconia is present on the ground surface. With the fault as a component in the model, a coverage file that encompasses the Fault Zone can be calibrated and also alternative parameters can be tested just to see how the fault interacts with the entire model and the capture zone of Rochelle under varying parameters. Although from literature, it is known that the Fault Zone ca be treated as a no flow, there is still a lot of uncertainty associated with every model. Testing of different probable scenarios will help draw the overall big picture. 


\section{CHAPTER VI: CONCLUSIONS}

Design and construction of public supply wells usually takes into consideration how to bypass contaminants that is both anthropogenic and natural sources. One of the approach in understanding sources of contaminants is to examine the contributing areas within the aquifer that provides water to a particular well or group of wells. Rochelle is a town located within north central Illinois that supply water to the inhabitants using groundwater. This study was designed to understand the contributing areas and flow pattern of the groundwater in Rochelle and the surrounding area in order to assess sources of radium contamination. Two main research questions were examined to address which area contributes water to Rochelle's PWSW by conducting capture zone analysis. A steady-state model was set up and calibrated, then different pumping scenarios were inputted into the model to understand the capture zone created by the wellfield. The major findings of this study are:

1. The head distribution results from the calibrated model agrees with the structure (dips) of the hydrostratigraphic units and the different level of pumping for different pumping centres within northern Illinois. The hydrostratigraphic units dip SE as well as higher pumping rate in the eastern section of the study area resulted in a head drop that goes from northwest to southeast.

2. Two major cone of depression were delinated by the capture zone anlysis, (1) cone of depression created by pumping wells in Rochelle town area and (2) cone of depression in DeKalb area (east side).

3. Withdrawal from the scenario models showed the regional groundwater divide between Rochelle and DeKalb still present. The two major cones of depression couldn't converge as a result of the presence of regional groundwater divide preventing flow reversal. Probabaly a transient model could help better simulate the shift in groundwater divide and also increase in pumping centres close to the divide can reduce the presence of the divide and trigger flow reversal from northeastern part of model to Rochelle. 
4. The capture zones from the stochastic model showed leakage occuring from the Franconia Formation into the Ironton-Galesville aquifer.

5. All the stochastic models confirmed that the capture zone of the Rochelle area wellfield is asymetrical toward the southern boundary of the model domain where the Sandwich Fault is located.

6. Mass balance results and cross sectional pathlines confirmed that leakage occurs from the overlying Franconia Formation to the Ironton-Galesville aquifer.

To sum it all up, the scenario models showed the likelihood of water travelling from DeKalb to Rochelle isnt possible. However, the capture zones and mass balance results showed leakage from the overlying Franconia Formation into the Ironton Galesville aquifer, hence the source of Ra being from the Franconia Formation. Further research into the transport of radium is necessary since this work mainly focuse on understanding the flow paths and to test the hypothesis of water moving from the Franconia Formation into the Ironton-Galesville aquifer when pumping. 


\section{REFERENCES}

Abrams, D.B., Hadley, D.R., Mannix, D.H., Roadcap., S., Meyer, C.S., Hinka, K.J., Rennels, K.L., Bradbury, R., Chase, M.P., Krause, J.J., 2015, Changing Groundwater Levels in the Sandstone Aquifers of Northern Illinois and Southern Wisconsin: Impacts on Available Water Supply: Illinois State Water Survey and Wisconsin Geological and Natural History Survey, Champaign, IL

Abrams, D.B., Roadcap, G.S., Mannix, G.H., Hadley, D.R., 2018, The Illinois Groundwater Flow Model: Illinois State Water Survey, Champaign, IL

Anderson, M.P., Woessner, W.W., Hunt, R.J., 2015, Applied Groundwater Modeling- Simulation of flow and advective transport ( $2^{\text {nd }}$ Edition): San Diego, Academic Press Inc., 564 p.

Ayotte, J.D., Szabo, Z., Focazio, M.J., Eberts, S.M., 2011, Effects of human induced alteration of groundwater flow on concentrations of naturally-occurring trace elements of water-supply wells: Applied Geochemistry, v. 26, p. 747-762. doi: org/10.1016/j.apgeochem.2011.01.033

Buch, S.L., 2008, A comparison of Potentiometric Surfaces of the Cambrian-Ordovician Aquifers of Northeastern Illinois: Illinois State Geological Survey, Institute of Natural Resources Sustainability.

Carlock, E., Peterson, E.W., Malone, D.H., 2016, Three dimensional Geologic Modeling and Groundwater Flow Modeling above a C02 sequestration Test Site: Open Journal of Modern Hydrology, v. 6, no. 3, p. 182-193, doi: 10.4236/ojmh.2016.63015

Charley, Y., Sunita, K., Cheng, W., Jing-Jy, C., 2015, Data Collection Handbook to Support Modeling Impacts of Radioactive Material in Soil and Building Structures. United States, doi:10.2172/1224969 
Feyen, L., Beven, K.J., Smedt, F.D., Freer, J., 2001, Stochastic capture zone delineation within the generalized likelihood uncertainty estimation methodology: Conditioning on head observations: Water Resources Research, v.37, no.3, p.625-638, doi: 10.1029/2000WR900351

Fitts, C.R., 2013, Groundwater Science (Second Edition): Boston, Academic Press, 671 p.

Greer, C.B., 2009. Recharge Analyses into Shallow Glacial and Depp Bedrock Aquifers Related to the Troy Bedrock Valley System, DeKalb County, Illinois: Geological Society of America Abstract with Programs. Portland, Oregon, v. 41, no.7, p.213

Hadley, D.R., and Abrams, D.B., 2018, Revisiting one of the largest aquifer tests in history: Implications for Fault Zone Hydrogeology and the declining groundwater supply in Northeastern Illinois: Geological Society of America Abstract with Programs. Ames, lowa, v. 50, no. 4, doi: 10.1130/abs/2018NC-312815

Hadley, D.R., Roadcap, G.S., Hlinka, K.J., Young, T., 2016, Lessons from a Borehole: Using Head Differences and Geophysical Logging in a Nested Well to Conceptualize Groundwater flow Across the Sandwich Fault Zone in Northern Illinois: Geological Society of America Abstract with Programs. Denver, Colorado, v. 48. No. 5, doi: 10.1130/abs/2016NC-275482

Harbaugh, A.W, 2005, MODFLOW-2005, The U.S. Geological Survey Modular Ground-Water Model- the Ground-Water Flow Process: US Geological Survey

Kay, R.T., 1999, Radium in Groundwater from public-water supplies in Northern Illinois, United States Geological Survey Fact Sheet 137-99, DeKalb, IL

Kelly, W.R., 2008, Radium and Barium in the Ironton- Galesville Bedrock Aquifer in Northeastern Illinois: Illinois State Water Survey, Centre for Groundwater Science Report, Champaign, IL, 36p Khadri, S.F.R., and Pande, C., 2016, Ground water flow modeling for calibrating steady state using MODFLOW software; a case study of Mahesh River basin, India: Modeling Earth Systems and Environment, v. 2, no. 1, p. 39, doi: org/10.1007/s40808-015-0049-7 
Kolata, D.R., 2014, Bedrock Geology of Daysville Quadrangle, Ogle County, Illinois: Illinois State Geological Survey USGS-STATEMAP contract report, scale 1:24,000, 2 sheets

Kolata, D.R., Buschbach, T.C., Treworgy, J.D., 1978, The Sandwich Fault Zone of northern Illinois: Illinois State Geological Survey Circular 505, 26p

Kolata, D.R., and Graese, A.M., 1983, Lithostratigraphy and depositional environments of the Maquoketa Group (Ordovician) in northern Illinois: Champaign, Illinois, Illinois State Geological Survey Circular 528, 49p

Krohelski, J.T., and Feinstein, D.T., 2007, Effect of pumping on direct and indirect groundwater flow to Lake Michigan and on groundwater flow between the Mississippi river and Lake Michigan basins: United State Geological Survey

Landmeyer, J.E., 1994, Description and application of Capture Zone delineation for a wellfield at Hilton Head Island, South Carolina: US Geological Survey, Water resources investigation report 944012, $37 \mathrm{p}$

Lau, J., Thomason, J.F., Malone, D.H., Peterson, E.W., 2016, Three-Dimensional Geological Model of Quaternary Sediments in Walworth County, Wisconsin, USA: Geoscience, v. 6, no. 3, p. 32, doi: org/10.3390/geosciences6030032

Luczaj, J.A., McIntire, M.J., Hunt, M.O., 2016, Geochemical Characterization of Trace MVT Mineralization in Paleozoic Sedimentary Rocks of Northeastern Wisconsin, USA: Geoscience, v. 6, no. 2, p. 29, doi: org/10.3390/geosciences6020029

Lin, Y.P., Chen Y.W., Chang, L.C., Yeh, M.S., Huang, G.H., Petway, J.R., 2017, Groundwater Simulations and Uncertainty Analysis Using MODFLOW and Geostatistical Approach with Conditioning MultiAquifer Spatial Covariance: Water, v. 9, no. 3, 164 
Mahmud, K., Mariethoz, G., Baker, A., Sharma, A., 2015, integrating multiple scales of hydraulic conductivity measurements in training image-based stochastic models: Water Resources Research, v. 51, no. 1, p. 465-480, doi: org/10.1002/2014WR016150

Mannix, D.H., Abrams, D.B., Hadley, D.R., Roadcap, G.S., 2018, Conceptualizing leakage and storage contribution from long open interval wells in regional deep basin flow model: Hydrological Processes, v. 33, no. 2, p. 271-282, doi: org/10.1002/hyp.13324

Meyer, S.C., Lin, Y., Abrams, D.B., Roadcap, G.S., 2013, Groundwater Simulation Modeling and Potentiometric Surface Mapping, McHenry County, Illinois: Illinois State Water Survey Contract Report 2013-06

Moise, T.A., Starinsky, A., Katz, A., Kolodny, Y., 2000, Ra isotopes and Rn in brines and ground waters of the Jordan-Dead Sea Rift Valley: enrichment, retardation, and mixing: Geochimica et Cosmochimica Acta, v. 64, no. 14, p. 2371- 2388, doi: 10.1016/S0016-7037(00)00369-0

Niswonger, R.G., Panday, S., Ibaraki, M., 2011, Techniques and Methods: Reston, US Geological Survey, p. $1-56$.

Panno, S.V., Askair, Z., Kelly, W.R., Parris, T.M., Hackley, K.C., 2018, Recharge and Groundwater Flow within an Intracratonic Basin, Midwestern United States: Groundwater, v. 56, no. 1, p. 32-45, doi: $10.1111 /$ gwat.12545

Pollock, D.W., 2012, User Guide for MODPATH Version 6- A Particle- tracking Model for MODFLOW: Washington, DC, U.S. Geological Survey Techniques and Methods 6-A41, 58p.

Rayne, T.W., Bradbury, K.R., Zheng, C., 2013, Correct Delineation of Capture Zones Using Particle Tracking under Transient Conditions: Groundwater, v. 52, no. 3, doi: org/10.1111/gwat.12141 Rhoads, M, 2017, Exploration of the Northern Illinois Bedrock Surface [MS Thesis]: Illinois State University, $42 p$ 
Rhoads, M.L., Malone, D.H., 2018, Preglacial paleotopography at the eastern terminus of the Plum River Fault Zone, Ogle County, Illinois: Environmental Geosciences, v. 25, no. 3, p. 101-119

Reinersten, D.L., 1990, Guide to the geology of the Oregon area, Ogle County, Illinois State Geological Survey, Department of Energy and Natural Resources, p. 1-10

Seid, M.J., 2010, Bedrock geology of Oregon Quadrangle, Ogle County, Illinois; Illinois State Geological Survey USGS STATEMAP contract report, scale 1:24,000, 2 sheets.

Seneviratne, A.A.A.K.K, 2007, Development of Steady State Groundwater Flow Model in Lower Walawa Basin- Sri Lanka [MSc. Thesis]: Enschede, International Institute for Geo-information Science and Earth Observation, $103 p$

Sengor, S.S., and Unlu, K., 2013, Modeling contaminant transport and remediation at an acrylonitrile spill site in Turkey: Journal of Contaminant Hydrology, v. 150, p. 77-92, doi:

10.1016/j.jconhyd.2013.02.010.

Seyoum, W.M., and Eckstein, Y., 2014, Hydraulic relationship between buried valley sediments of the glacial drift and adjacent bedrock formations in northeastern Ohio, USA: Hydrogeology Journal, v. 22, p. 1193-1206 doi: doi.org/10.1007/s10040-014-1128-y.

Seyoum, W., 2012, Hydraulic Relationship between Buried Valley Sediments and Adjacent Bedrock Formations [MSc. Thesis]: Kent, Kent State, $141 \mathrm{p}$

Stackelberg, P.E., Szabo, Z., Jurgens, B.C., 2018, Radium mobility and the age of groundwater in public drinking water supplies from the Cambrian-Ordovician aquifer systems north-central USA: Applied Geochemistry, v. 89, p. 34-38, doi: org/10.1016/j.apgeochem.2017.11.002

Szabo, Z., DePaul V.T., Fischer, J.M., Kraemer, T.F., Jacobsen, E., 2012, Occurrence and Geochemistry of radium in water from principal drinking-water systems of the United States: Applied Geochemistry, v.37, no. 3, p. 729-752, doi: org/10.1016/j.apgeochem.2011.11.002 
Thwaites, F.T., 1927, Stratigraphy and Geologic structure of Northern Illinois: Illinois State Geological Survey, Champaign, IL

Visocky, A.P., Sherrill, MG., Cartwright, K., 1985, Geology, Hydrology, and Water Quality of the Cambrian and Ordovician Systems: Illinois State Geological Survey

Weaver, T.R., and Bahr, J.M., 1992, Geochemical Evolution in the Cambrian-Ordovician Sandstone Aquifer, Eastern Wisconsin; Correlation between Flow Paths and Ground-Water Chemistry: Groundwater, v. 29, no. 4, p. 510-515, doi: org/10.1111/j.1745-6584.1991.tb00542.x

Yidana, S.M., Alo, C., Addai, M.O., Fynn, O.F., Essel, S.K., 2015, Numerical Analysis of groundwater flow and potential in parts of a crystalline aquifer system in Northern Ghana: International Journal of Environmental Science and Technology, v. 12, no. 12, p. 3805-3818, doi: org/10.1007/s13762015-0805-2

Zhou, J., and Sha, Z., 2013, A New Spatial Interpolation Approach Based on Inverse Distance Weighting: Case Study from Interpolating Soil Properties: Communication in Computer and Information Science, v. 399, p. 623-631, doi: 10.1007/978-3-642-41908-9_61

Zhou, Y., and Li, W., 2011, A review of regional groundwater flow modeling: Geoscience Frontiers, v. 2, no. 2, p. 205-214, doi: org/10.1016/j.gsf.2011.03.003 